\title{
Direct democracy and intergenerational conflicts in ageing societies*
}

\begin{abstract}
To evaluate the potential effects of population ageing on the outcomes of direct democracy, we analyze the effect of age on voting decisions in public referendums. In a case study of the Stuttgart 21 referendum on one of the largest infrastructure projects in Germany, we find that support for the project decreased significantly in age. A quantitative review of the relevant literature affirms that similar lifecycle patterns appear to be the norm in referendums on projects that require initial expenditures and pay off in the long run. Population ageing, thus, presents a potential threat to investment-like reform projects.
\end{abstract}

Key words: Ageing, direct democracy, intergenerational conflict, NIMBY, referendum, Stuttgart 21, transport, voting Version: December 2018

JEL: D61, D62, H41, H71, L83, I18, R41, R58

\section{Introduction}

In the world of 2047, children will be outnumbered by persons aged 60 years and above for the first time in history. Compared to 2013, the share of the latter age group at the world population will almost double to $21.1 \%$. The median age will increase by one third, from 29.1 to 39.1 years. In developing countries, the ageing of society will have progressed even further by 2050. In the US, the share

- London School of Economics and Political Sciences (LSE) and Centre for Economic Policy Research (CEPR), Houghton Street, London WC2A 2AE, g.ahlfeldt@lse.ac.uk, www.ahlfeldt.com

- University of Hamburg, Department of Economics, Chair for Economic Policy, Von-Melle-Park 5, 20146 Hamburg, wolfgang.maennig@wiso.uni-hamburg.de

- University of Hamburg, Department of Economics, Chair for Economic Policy, Von-Melle-Park 5, 20146 Hamburg, malte.steenbeck@wiso.uni-hamburg.de

* We are grateful to Johannes Blumenberg for his help with the post-election survey data analysis. Alex Ram and Steffen Müller provided excellent research assistance. We thank the editor, Steven Brakman, and two anonymous referees for excellent comments and suggestions. We would further like to thank the participants at seminars and conferences in Berlin, Berne, Hamburg, Leipzig, London, Vienna, and, in particular, Fabio Canetg, Paul Cheshire, Dennis Coates, Christian Hilber, Stephen Gibbons, Henry Overman, Maximilian von Ehrlich, and Bernd Süssmuth, for comments and suggestions. This research did not receive any specific grant from funding agencies in the public, commercial, or not-for-profit sectors. 
of persons aged 60 and above is projected to increase to 27\%. In Germany, the same share will escalate to almost $40 \%$ and the median age will exceed 50 years. ${ }^{1}$

This unprecedented population ageing has both diverse and substantial economic implications. Just to name a few, population ageing puts pressure on social security systems (Breyer and Stolte, 2001; Demange and Laroque, 1999) and potentially affects returns of capital (Abel, 2001; Krueger and Ludwig, 2007; Poterba, 2001), economic growth prospects (Acemoglu and Johnson, 2007; HoltzEakin et al., 2004), and the city size distribution (Gaigné and Thisse, 2009). The implications for the political economy are potentially similarly significant. In a theoretical paper, Messner and Polborn (2004) make the compelling case that many "reform projects" share similarities with investments in that they require some initial expenditure and pay dividends over a long period. Accordingly, optimal decisions should maximize the expected utility of an individual who is newly born into society and will face the costs and benefits of a project over the entire lifecycle. But unless they are guided by altruism, voters of all ages will likely maximize their individual expected utility conditional on their stage in the lifecycle, i.e. the discounted costs and benefits expected during their remaining lifetime. As voters age, the period over which they expect to receive the benefits decreases so that they become more conservative (against reforms).

One instance where lifecycle-specific attitudes toward public policies become apparent and immediately relevant is in direct democracy processes such as public referendums. ${ }^{2}$ Since 1978 , there has been a storm of ballot-box lawmaking in the US, in virtually every field of policymaking (Matsusaka, 2005). Over $70 \%$ of the US population lives in states or cities where direct democracy is an established option for political decision-making (Matsusaka, 2004). Moreover, direct democracy is spreading internationally. In many countries, it has become almost expected that first-order issues affecting national sovereignty be carried directly to the voters. Examples include various referendums on European Union monetary and market integration, the 2004 "peace referendum" in Taiwan to define relations with mainland China, or the 2014 referendum on Scottish independence from the UK.

Anecdotally, an impressive intergenerational conflict has recently been documented for the 2016 "Brexit" referendum, in which a majority of UK citizens voted to leave the European Union. While

1 All figures are taken from the 2013 UN World Population Ageing report and the corresponding Profiles of Ageing 2013 interactive database (United Nations, 2013).

2 In the US, a referendum differs from an initiative in that the former is a vote on a law that is already approved by the legislature, while the latter is a vote on a law proposed by citizens. Throughout this paper, we use the term referendum as referring to any election in which citizens have a direct vote on a law. 
polls suggested that among pensioners a clear majority of 59\% supported a British exit, the same proportion was as low as 19\% among the 18-to-24-year-olds (Shuster, 2016). There is, however, no systematic evidence regarding a generational divide in the attitudes expressed in public referendums. The existing empirical analyses of direct votes do not normally focus on age-related effects; where age is considered a determinant of the voting decision, it is typically viewed as a potentially confounding factor that is not central to the analysis. ${ }^{3}$ As a result, the evidence base is scattered across studies in separate, unconnected literature strands. A solid evidence base regarding the nature of age-related voting in public referendums, however, is critical to understanding the implication of population ageing for the outcomes of direct democracy.

To inform the literature, we provide case study evidence on the generational divide in voter attitudes towards one of Germany's largest current transport project and the first quantitative survey of the existing evidence on age effects in public referenda. We analyze the 2011 Stuttgart 21 referendum, in which voters were asked to either support or reject the development of a new central rail station in Stuttgart, Germany. ${ }^{4}$ The new station, including all feeder lines, would be developed underground, freeing up the current track beds for urban redevelopment. For our purposes, the Stuttgart 21 referendum makes an interesting study case for a number of reasons. First, it is a large referendum, in the sense that 7.6 million eligible voters in the German state of Baden-Württemberg were called to the ballots to decide on a €6.5 (\$9) billion project. ${ }^{5}$ Second, a construction period of at least 10 years was expected, during which there would be significant disruptions in urban and regional transit. Therefore, the expected net present value of the project should decline in an individual's age if benefits to other generations are ignored. Third, population ageing is progressing particularly rapidly in Germany, making it an interesting country in which to quantify the possible effects on referendum outcomes.

Following a vivid and controversial pre-referendum campaign, the project was approved by a relatively clear 58.9\% majority, and the turnout was relatively high at $48.3 \%$. Controlling for other factors, we find that an increase in the average age of the adult population within a municipality by one

3 The exception is a literature on support for educational expenditures discussed below.

4 Wagschal (2013) analyzes the same referendum using more aggregated data.

5 The $€ 6.5$ billion is a number circulated in the media at the time of the referendum, up from an initial costing of $€ 3$ billion, plus a risk buffer of $€ 1.4$ billion. As of January 2018, the financial framework comprises $€ 8.2$ billion. Throughout the paper, we use a $\$ / €$ exchange rate of 1.392 , the mean rate in 2011 , which is the year of the Stuttgart 21 referendum. 
year was associated with an about one-percentage-point increase in the share of votes opposing the project. Using instruments to remove shocks that simultaneously determine the age structure of and preferences toward Stuttgart 21 tends to increase the estimated age effect. By combining our casestudy estimates of the age effect with a population projection we provide an exemplary illustration of the quantitative relevance of population ageing for direct democracy outcomes. This back-of-theenvelope calculation in the spirit of Poterba (1998) suggests the age effect is large enough for population ageing to cause a sizable impact on referendum outcomes over the coming decades. However, since age and cohort effects cannot be separated in a cross-sectional referendum analysis, this quantitative interpretation rests on the strong and untestable assumption that the birth year, conditional on age, is not a significant determinant of the voting outcome.

To analyze the external validity of our case study results and to explore the mechanisms through which age effects materialize, we conduct the first quantitative survey on the evidence of age effects revealed in empirical analyses of public referendums. In our quantitative survey, we cover 112 referendum analyses in 33 studies and approximately 400 million individual voting decisions on a wide range of topics, including spending on public schools, political integration, infrastructure projects, energy, welfare policies, and the environment. ${ }^{6}$ For each analysis, we examine the direction and significance of the effect associated with an age-related variable, and categorize the implied voter attitude as either individualistic (an age effect consistent with individual expected utility maximization), neutral (no significant age effect), or collectivistic (an age effect consistent with maximization of expected utility of other generations), depending on the particular context. These terms are borrowed from psychology literature, which analyzes the extent to which individuals give priority to personal (individualistic) or group (collectivistic) goals (Oyserman et al., 2002; Triandis, 1995).

In almost $50 \%$ of the cases, the results in the literature imply individualistic voter attitudes, while less than $10 \%$ reveal significant age effects in the opposite, collectivistic direction. The remaining studies reveal statistically insignificant age effects. This individualistic tendency is particularly evident in referendums on public school funding, health services, welfare policies, international integration, and energy-related questions. However, for instance in referendums on sports and culture, ur-

6 See Appendix II, Section 3, for a discussion of our approximation of the total votes covered. 
ban development, or largely moral issues such as abortion policies, animal protections, or equal opportunity policies, the voting decision does not significantly depend on age in the majority of cases analyzed.

The quantitative review helps evaluating alternative explanations that may theoretically account for the age effect in our Stuttgart 21 study. For one thing, it seems unlikely that the age effect is related to attitudes towards the environment as voter age is generally negatively correlated with support of environmental protectionism in the evidence base. For another, we find that if the temporal costbenefit structure is reversed compared to the standard reform project Messner and Polborn (2004) have in mind, the direction of the age effect also changes. As an example, there is evidence that age increases the likelihood of supporting a reduction in expenditures on education (e.g. Ladd and Wilson, 1983; Rubinfeld, 1977). Moreover, a status-quo orientation due to habituation (Samuelson and Zeckhauser, 1988) is not sufficient to rationalize lifecycle-specific voting, suggesting a role for the temporal cost-benefit structure argument developed by Messner and Polborn (2004).

Our results contribute to a number of strands in the political economy, public economics, and urban economics literature. We directly connect to literature that has investigated intergenerational conflicts against the background of population ageing (Brunner and Balsdon, 2004; Holtz-Eakin et al., 2004; Ladd and Murray, 2001; Poterba, 1998). Moreover, we relate to literature that has analyzed how interest groups (Ahlfeldt and Maennig, 2015; Ahlfeldt et al., 2017; Dehring et al., 2008; Fischel, 2001a; Lawley and Furtan, 2008) and those with the "not-in-my-backyard" attitude (NIMBYs) (Feinerman et al., 2004; Fischel, 2001b; Frey et al., 1996), seek to influence political outcomes. In general terms, we contribute to major strands in economics literature that are concerned with political opposition to projects with positive net present value (Fernandez and Rodrik, 1991; Kahneman et al., 1991), the nature of direct-democratic decision making (Deacon and Shapiro, 1975; Feld and Matsusaka, 2003; Matsusaka, 2004; Osborne and Turner, 2010), and the economics of accessibility and transportation (Ahlfeldt et al., 2015; Baum-Snow, 2007; Duranton and Turner, 2012; McCoy et al., 2018).

The remainder of the paper is structured as follows. Section 2 presents our case study on Stuttgart 21. Section 3 analyzes the relationship between voter age and incentives by means of a quantitative literature survey. Finally, Section 4 presents our conclusions. 


\section{The case of the Stuttgart 21 referendum}

\subsection{Background}

The Magistrale for Europe, a high-speed rail (HSR) that runs from Paris, France to Bratislava, Slovakia, is a central element of the Trans-European Transport Network (TEN-T). This corridor requires an HSR connecting the German state capitals of Munich (Bavaria) and Stuttgart (Baden-Württemberg). In order to increase capacity and reduce travel time on the HSR, the redevelopment of Stuttgart's central terminus station into an underground through station was proposed. After the first plans were presented in 1994, it took more than 10 years until the final plans for the new station, routing of the feeder lines, and tunnel works were officially approved in early 2005. By April 2006, all legal appeals against the project were rejected. Three years later, a final agreement on the financing of the Stuttgart 21 project was signed in April 2009. Under the agreed terms the project became a public-private partnership with mixed funding coming from the rail carrier Deutsche Bahn, the German federal state, the state of Baden-Württemberg, the city of Stuttgart, and other stakeholders such as the Stuttgart airport (Stuckenbrock, 2013).

After the construction work on Stuttgart 21, the official title of the project, started in February 2010, protests against the project steadily increased, even reaching the traditionally non-agitated milieus. The protests achieved wide coverage in German mass media which reported the opposition to be driven by elderly milieus. To give some examples, the Westdeutsche Zeitung reported that older citizens from all political backgrounds took to the streets (Lumme, 2010). Reimann (2010), in Der Spiegel, used the Stuttgart 21 example to connect elderly opposition to reform projects to the phenomenon of population ageing. Kurbjuweit (2010), in his widely cited essay "Der Wutbürger," meaning enraged citizen, is so upset about the elderly's fierce opposition to Stuttgart 21 and their disregard of the future that he concludes that as Germany ages, it grows weak ["Weil Deutschland altert, erlahmt es auch"].

On September $30^{\text {th }}$, conflicts with authorities escalated during an attempt by police forces to clear an occupied public park in the immediate vicinity of the building site, resulting in 116 injuries (Stuckenbrock, 2013). Excessive costs and inconvenience during the construction period were the primary concerns brought forth by critics (Kröger, 2010). The projected costs amounted to $€ 6.5$ (\$9, 2011 exchange rate) billion in the Stuttgart metropolitan region alone. Even in a wealthy federal state with a 2011 GDP per capita close to that of the state of New York, these costs were perceived by many 
as excessive. ${ }^{7}$ Moreover, the construction period was expected to last at least 10 years, during which significant disruptions were expected, in particular, for the regional commuter rail network. Proponents argued that the costs were justified in light of the expected travel-time savings, expected creation of jobs, and potential revenues and opportunities for urban development, resulting from the redevelopment of the former track beds (Wagschal, 2013).

After the state elections in March 2011, the leading green party and social democrats formed a coalition. Since a central position of the green party was to oppose Stuttgart 21, while the social democrats supported the project, the parties agreed to delegate the decision to the voters in a public referendum. On November 27th, about 7.6 million eligible voters in Baden-Württemberg were called to the ballots to decide whether the state should exercise its right to withdraw the $€ 930$ million ( $\$ 1.3$ billion) contribution to the project. A yes vote, thus, implied a vote against Stuttgart 21. Given the abovementioned large attention that the project received in the media, it is reasonable to assume that the voters were well informed about the topic and the potential consequences of their decisions. Backed by a relatively high turnout of $48.3 \%$, an unexpected yet clear majority of $58.9 \%$ voted no and, therefore, in favor of one of Germany's largest infrastructure projects in the foreseeable future. For additional institutional background, see Appendix I, Section 2.

\subsection{Empirical strategy}

In analyzing the Stuttgart 21 referendum, we assume that voters who participate in a public referendum support the alternative that maximizes their expected utility. The temporal benefit-cost structure of Stuttgart 21 resembles that of a reform project as modelled by Messner and Polborn (2004), i.e. there is a large initial expenditure and a continuous stream of benefits over a long period. The expected individual net utility of a voter should decrease with age since a lower remaining life expectancy implies shorter exposure to the benefits (travel-time savings) and, in relative terms, stronger exposure to costs (opportunity cost and disruptions). Any positive wider economic impacts are also less immediately relevant to voters who are already retired or expect to be retired in the near future. ${ }^{8}$ Intergenerational altruism or an interest in maintaining a strong economy to sustain the pension and

7 In 2011, Baden-Württemberg had a GDP per capita of €35,802 or \$49,851, taking the mean 2011 \$/€ exchange rate as a basis. As a comparison, the state of New York had a GDP per capita of $\$ 52,657$, ranking $7^{\text {th }}$ in the US.

8 The transport appraisal literature distinguishes between user benefits, which mainly capture the value of shorter travel times, and wider economic impacts, such as agglomeration benefits due to higher effective density, moves to more productive jobs, and output changes in imperfectly competitive markets (Department for Transport, 2014). 
health systems potentially compensate for these incentives. Experience with similar projects in the past combined with a sense of morale could theoretically imply that the likelihood of support could increase with age, if the project is perceived as socially desirable. ${ }^{9}$

We acknowledge the existence of alternative mechanisms through which an age effect could materialize. Older voters could have opposed the project because of environmental concerns or simply due to habituation (Samuelson and Zeckhauser, 1988). Although these alternative explanations are less consistent with the anecdotal evidence summarized in Section 2.1 (Kröger, 2010; Kurbjuweit, 2010; Lumme, 2010), we return to this question after reviewing the relevant evidence base in a quantitative literature review (in Section 3).

It is noteworthy that theoretically a higher remaining life expectancy can mitigate the effect of a higher age. However, while there is some variation in life expectancy across regions in Baden-Württemberg, we find that, conditional on controlling for age, life expectancy does not have a significant impact on the referendum outcome (neither remaining life expectancy at birth nor at the age of 60). Either voters are not fully aware of their regionally varying life expectancy, or they value the final years of their life relatively low. In this case, a larger remaining lifetime conditional on reaching a high age will have a marginal impact on voting decisions. We also note that controlling for life expectancy hardly affects the estimated age effect. To keep the analysis compact and consistent with the literature reviewed in Section 3 we therefore focus on age as the variable of primary interest. For the interested reader, we provide a discussion of remaining life expectancy effects in Section 10 of Appendix I.

To examine the relationship between expected utility and age, we follow what has become standard practice in the literature and relate the opposition to Stuttgart 21 in the referendum to the average age of the electorate, using a linear model (e.g., Ahlfeldt and Maennig, 2015; Brunner et al., 2001; Coates and Humphreys, 2006; Dehring et al., 2008):

$$
\operatorname{PRCNTYES}_{i}=\alpha+\beta A G E_{i}+\gamma S_{i}+X_{i} \mu+\varepsilon_{i}
$$

The opposition to Stuttgart 21 is expressed as the percentage of yes votes of the total votes for municipality $i$ (PRCNTYES). $A G E_{i}$ is the average age of the adult population that is entitled to participate in the referendum. We add a variable, $S$, to the model, which captures the net effect of the expected

9 The transport appraisal for planned local transportation measures revealed a benefit-cost ratio of 2.95 (Verkehrswissenschaftliches Institut Stuttgart and Intraplan Consult, 2006). 
accessibility upgrade and the localized disruptions during the construction period. Outside the Stuttgart region, the financial burden on municipalities and citizens associated with the project does not vary within Baden-Württemberg. We experiment with different measures, described in more detail in the data section, including the straight-line distance from Stuttgart and a gravity measure, which incorporates the expected changes in the bilateral connectivity as well as the bilateral commuting probabilities between municipalities. With the vector of further covariates $X$, we seek to disentangle the age effect from the effect of other locational factors that have an independent effect on the voting outcome and are correlated with age. The controls are listed in Table 1. A theoretical motivation is provided in Appendix I, Section 4.1. $\beta$ (of primary interest), $\gamma$, and $\mu$ (a vector) are the parameters to be estimated, and $\varepsilon_{i}$ is a random error term.

In estimating $\beta$, we face several challenges. First, it is possible that voter attitudes differ systematically across birth cohorts as they lived through their "impressionable years" in different social and political environments (Krosnick and Alwin, 1989). The standard problem in the cross-sectional analysis of age effects in referendums is that the effects of age and birth year cannot be separately identified. Assume that there is a structural version of (1) in which the effect of age and birth year $B_{i}$ on the voting outcome are described by the additive terms $c A G E_{i}$ and $d B_{i}$. Since $A G E_{i}=t-B_{i}$, where $t$ is the year in which the referendum takes place, we have $\beta=c-d$ in the reduced-form equation (1). Thus, for $\beta$ to represent a causal effect of age, we must assume that $d=0$, i.e. that the birth year has no effect on the outcome, a strong yet untestable assumption.

Second, in selecting a set of covariates to be included in $X$, we face the tradeoff between allowing for an omitted variable bias and introducing an included variable bias that arises when a control is endogenous to the variable of interest (also referred to as a bad control problem). Our approach to selecting suitable covariates is inspired by Angrist \& Pischke (2009). If, in auxiliary regression of a covariate against age, the latter has an insignificant effect on the former, we consider the covariate to be unlikely a bad control and add it to a set of parsimonious controls. If the effect of age on the covariate is significant but the theoretical case for a causal relationship is not very strong, the covariate is added to a set of preferred controls. If the effect of a covariate on age is statistically significant, quantitatively large, and a causal effect is likely on theoretical grounds (as in the case of choice variables such as political party affiliation), we add the covariate to a set of demanding controls. We argue that conditional on the parsimonious set of controls, the estimated age effect likely represents an upper-bound estimate that suffers from omitted variable bias. Conditional on the demanding set of controls, the age effect likely represents a lower-bound estimate that suffers from included variable 
bias. The set of preferred controls represents a compromise that hopefully balances the effects of the two types of specification biases. The list of covariates in the different sets of controls is given in Table 1. For the interested reader, we provide a more detailed discussion of the selection process and a formal description of the included variable problem in Appendix I, Section 4.2.

Third, controlling for observables is a naturally imperfect solution to the omitted variable problem since there may be unobservable components in the error term $\varepsilon_{i}$ that are correlated with the average of the electorate. Voters of certain age groups may prefer living in certain municipalities where, regardless of age, voters tend to have a specific view on the project in question. Some examples that would give cause for concern include a particular preference for certain modes of transportation, the valuation of the environment, or attitude toward technological innovation, among other things, which are difficult to control for. To explore the direction of a potential bias, we propose a 2SLS strategy and four sets of instrumental variables (IVs) that capture economic conditions lagged by several decades. We argue that these historic conditions do not have an impact on the outcome other than through an effect on the contemporary age composition.

In the lagged children IVs, we include the share of children (aged 0-6 and 6-15) in the total population in 1950 and 1961. These instruments will have some predictive power for the age distribution in 2011 if a significant fraction of the population stays put or returns to their birthplace at some point, e.g. after they retire.

In the lagged sector IVs, we include the shares of the secondary and tertiary sectors of total employment in 1950, 1961, 1970, and 1987 (the last employment censuses in Germany before 2011) as instruments for average age in 2011. The intuition is that locations with, at some point in time, a favorable industry composition or transformation likely attracted a young mobile workforce. If a fraction of those movers then stayed put, there will be a legacy on the contemporary age distribution. We use sectoral shares at the county level because these represent a better approximation of a labor market area than do very small municipalities.

In the geology IVs, we include a set of dummy variables, each one indicating whether a municipality is within $100 \mathrm{~km}$ (the results are not particularly sensitive to the choice of the distance threshold) of one of the following mines: Baryte, feldspar, fluorite, petroleum, potash, salt rock. We argue that the instrument predicts historic industry composition (and the abovementioned legacy effect on contemporary average age) because access to natural resources was a relevant locational determinant 
for the manufacturing firms at times when shipping cost were relatively high (Fernihough \& O'Rourke, 2014).

In the World War II (WWII) destruction IVs, we include set of dummy variables indicating deciles in the distribution of the share of built capital destroyed during World War II across municipalities. The rationale is that the strategic bombing of German cities during WWII had sizable effect on the economic geography of Germany (and the abovementioned legacy effect on contemporary average age) as shown by Brakman et al (2004).

In order to more plausibly satisfy the exclusion restriction, we include contemporary sectoral shares in all IV models. This reduces the risk that our IVs capture the effects of serially correlated economic conditions that persist today. Moreover, we note that shipping costs have decreased significantly over time, so that there is much less reason to believe in a direct effect of proximity to natural resources on economic outcomes (Mohammed \& Williamson, 2004). Likewise, Brakman et al (2004) show that the effect of strategic bombing on the economic geography of Germany was temporary and, because of mean reversion, the contemporary effect is limited. In support of this line of argumentation, we show in Appendix I, Section 8 that the predictive power of the geology and WWII IVs for the size of the manufacturing sector and population growth quickly decreases over time. The same appendix section also provides additional details on the instruments, their construction, and the data sources, and additional evidence that supports the legacy effect of historic conditions on the contemporary age composition. To this end, we show that since the 1960s, population growth has been associated with reductions in average age, most likely because young mobile workers are attracted to economically successful regions. At the same time, industry shares in levels and trends are relevant predictors of population growth, which is in line with a growing literature started by Glaeser et al. (1992) and Henderson et al. (1995).

We subject our baseline empirical model to a number of robustness tests that have enjoyed some popularity in the literature. To allow for arbitrary spatial autocorrelation between neighboring communities, we adjust the standard errors according to Conley (1999) experimenting with various distance cut-offs. ${ }^{10}$ We use turnout as both a dependent and explanatory variable and, in the latter case,

10 Weights in the covariance matrix estimator linearly decline from 1 to 0 , reaching 0 at the predefined cutoff point. For our baseline models, we chose a cutoff of $15.6 \mathrm{~km}$, which corresponds to the average commuting distance in Baden-Württemberg in 2011 (Winkelmann, 2013). 
use the turnout in an earlier election as an instrumental variable (Vlachos, 2004). Following a tradition in the public-choice literature, we estimate a weighted (by the number of participating voters) version (WLS) and a binary choice (BC) logit version of Equation (1) (Deacon and Shapiro, 1975; Kahn and Matsusaka, 1997; Schulze and Ursprung, 2000). Besides considering different measures to capture the accessibility effects, we also consider the share of the elderly (aged 65 and older) as an alternative age-related variable, which has been popular in the literature. For the interested reader, we also provide a complementary analysis of individual-level post-election survey data in Appendix I, Section 11, which supports the results reported here.

\subsection{Data}

To analyze the Stuttgart 21 referendum, we collect a variety of data from different sources at the level of the 1,101 municipalities (Gemeinden) of Baden-Württemberg. We obtain the numbers of valid yes and no votes cast, as well as the number of eligible voters, from the statistical office of Baden-Württemberg. ${ }^{11}$ The population by age, gender, and education (academic degree holders) as well as the homeownership rate is available on the 2011 census website (www.zensus2011.de). The unemployment rate and income (taxable income per capita), as well as the shares of conservative and green party votes in the 2009 federal elections come from the regional statistics database of the Federal Statistical Office (www.regionalstatistik.de/genesis/online/logon). Data on the number of registered cars per municipality is obtained from the Federal Motor Transport Authority. With the exception of the 2009 federal elections, this data refers to 2011.

All data are at the municipality level, with the exception of the number of academic degree holders, which is not available for municipalities with a population of less than 10,000 . Full coverage was provided at the next higher geographic level, counties (Kreise und kreisfreie Städte). Within each county, we distribute degree holders that we cannot directly allocate to municipalities with a population of at least 10,000 to the remaining municipalities, assuming the share of degree holders follows a spatial autoregressive process. ${ }^{12}$

11 Our data includes $3,663,639$ out of $3,668,372$ votes. The remaining portion of less than $0.23 \%$ are postal votes in the small municipalities, which occasionally share a common voting district for votes by mail.

12 In interpolating the share of degree holders, we give higher weights to closer municipalities, using the following inverse exponential weights function: $w_{i j}=\exp \left(-\tau \times d_{i j}\right)$, where $\tau$ is a commuting decay parameter, estimated and discussed in more detail in Section 2 of Appendix I, and $d_{i j}$ is the distance between municipalities $i$ and $j$. 


\section{[TAB 1 ABOUT HERE]}

A central variable in our empirical analysis is the average age of the adult population, which forms the electorate. The 2011 census contains detailed information on the number of residents within oneyear age bins (e.g., 18, 19, 20, etc. years) for every municipality. The average age of the adult population, thus, can be computed as the average of all age bins, starting with the age of 18 , weighted by their respective shares of the adult population.

To create a measure of population density, we use the geographic surface area of the municipalities, provided by the Federal Statistical Office. Using a geographic information system (GIS) and electronic map provided by the Federal Agency for Cartography and Geodesy, we generate various distance measures, which strictly refer to the geographic centroids of the municipalities. To approximate the accessibility to Stuttgart 21, we compute the crow-flight distance from Stuttgart to each municipality.

In addition, as a more explicit measure of the expected long-term net-benefits of Stuttgart 21, we compute each municipality's (weighted) average change in travel time to all other municipalities in Baden-Württemberg. In computing this gravity measure for a given municipality we weight the expected change in travel time to another municipality by the respective commuting share. ${ }^{13}$ The expected travel-time changes are based on SMA und Partner AG (2010), a commissioned study that was accessed through the Department of Transport and Infrastructure of the State of Baden-Württemberg. A more detailed description of this measure is found in Appendix I, Section 2. The descriptive statistics of all variables are presented in Table 1 . The various data sources used for the construction of our IVs are described in the Appendix I, Section 8.

\subsection{Baseline results}

Figure 1 maps the opposition against Stuttgart 21, based on the share of yes votes against the rail geography in Baden-Württemberg, including the proposed HSR to Munich. A visual inspection suggests that opposition increases with distance from the Stuttgart 21 project, which is in line with the lower expected accessibility gains. At second glance, a tendency of lower opposition along the proposed HSR becomes evident. While, theoretically, the HSR could be realized independently of Stuttgart 21, the two projects were often related to each other in the public debate. Therefore, it is

13 Formally, the expected change in travel time $\Delta_{i}$ for municipality $i$ is defined as follows: $\Delta_{i}=\sum_{j} \frac{c_{i j}}{\sum_{j} c_{i j}} \Delta_{i j}$, where $\Delta_{i j}$ is the expected change in travel time between the two municipalities $i$ and $j$, and $c_{i j}$ is the number of workers commuting from $i$ to $j$. 
possible that some voters who supported Stuttgart 21 in the referendum were actually supporting the HSR because the rejection of Stuttgart 21 might have threatened the HSR project.

\section{[FIG 1 ABOUT HERE]}

In Figure 2, we turn our attention to the relationship between the opposition to Stuttgart 21 and average age of the electorate. The left panel displays a positive unconditional raw correlation between the average age of the electorate and opposition to Stuttgart 21. A one-year increase in the average age of the electorate is associated with a 1.79-percentage-point higher share of opposing yes votes. This is in line with the lifecycle-specific voting to maximize individual expected utility. Another notable, stylized fact is evident from Figure 2. Despite a relatively low average age, voters in some of the largest cities in the state, such as Freiburg, Heidelberg, Karlsruhe, and Mannheim, opposed Stuttgart 21. To some extent, this result can be rationalized by their relatively long distance from Stuttgart and the correspondingly low expected benefits. However, even in Stuttgart, the city that should accumulate the largest long-term benefits, there was a relatively large opposition, considering the average age of the electorate. This is suggestive of an urbanization effect, which could be driven by the particular values and attitudes of urban populations.

Therefore, it is reassuring that conditional on our preferred controls the voting outcome in the large cities is closer to the linear regression fit, as evident from the right panel of Figure 2 . The evident outlier among the large cities is Ulm. This is an intuitive result because, as illustrated in Figure 1, Ulm lies on the planned HSR connecting Stuttgart and Munich. To the extent that Stuttgart 21 and the HSR were perceived as complementary projects, voters in Ulm had an incentive to support Stuttgart 21. More generally, the correlation between the opposition to Stuttgart 21 and average age of the electorate remains reasonably strong when controlling for other factors. An increase in the average age by one year is associated with an increase in the share of yes votes by 1.06 percentage points. Moreover, expressed as an elasticity at the means of the distributions, a $1 \%$ increase in the average age is associated with a $1.44 \%$ increase in the share of yes votes. The respective partial correlation conditional on parsimonious and demanding controls are presented in Appendix I (Figure A4).

\section{[FIG 2 ABOUT HERE]}

In Table 2, we provide the results of the regressions of the share of yes votes (Columns (1)-(4)) and turnout (Columns (5)-(6)) against the average age and varying sets of covariates. Column (1) adds a distance from Stuttgart 21 control to the bivariate regression in Figure 2 (left panel). Proximity to Stuttgart 21 increases support for the project as expected. The marginal age effect decreases by some 
moderate 0.15 percentage points. Throughout Columns (2-4), we incrementally expand the set of controls from the parsimonious to the preferred to the demanding sets. Accordingly, a one-year increase in the average age of the electorate, depending on the ceteris paribus condition imposed, increases the opposition to Stuttgart 21 by 0.68 (lower-bound estimate conditional on demanding controls) to 1.50 (upper-bound estimate conditional on parsimonious controls) percentage points. The central estimate conditional on our preferred set of controls (identical to Figure 2, right panel), at 1.06 , turns out to be almost exactly halfway between the upper and lower bound estimates. Allowing for spatial autocorrelation (Conley errors in brackets) has moderate effect on standard errors. In Appendix I, Section 7, we show that the results are robust to using a broad range of distance cut-offs for the sphere of spatial autocorrelation. The estimated age effect is unlikely driven by a participation rate that varies in age, as the age effect on the turnout tends to be small and not statistically significant (see Columns (5) and (6) in Table 2). For the interested reader, we present a broader range of turnout models in Appendix I, Section 6.

As for the controls, we find that homeownership rate, share of academic degree holders, and population density are statistically significant and, given their relatively large standard deviations (see Table 1), empirically relevant predictors of the share of yes votes. We caution against interpreting the industry share coefficients since sectoral shares are highly correlated with each other. To put the magnitude of the age effect in Column (3) into perspective, a ceteris paribus increase in the average age by 10 years (7.6 S.D.) has the same effect on the share of yes votes (10.6 percentage points) as does an increase in the distance from Stuttgart by $97.25 \mathrm{~km}$ (2.6 S.D.), a decrease in the homeownership rate by 37.7 percentage points (4.0 S.D.), an increase in the share of academic degree holders by 27.9 percentage points (8.3 S.D.), or an increase in population density by 3,615 residents per square km (10.3 S.D.).

\section{[TAB 2 ABOUT HERE]}

\subsection{Robustness and extensions}

In Table 3, we alter the baseline model along a number of dimensions. To save space, we restrict the presentation to the primary variables of interest and focus on models including our preferred controls. Results for the full model and for models with the alternative controls are given in Appendix I, Section 7.

In the WLS model, wherein we attach proportionately higher weights to municipalities with a larger electorate, the age effect is lower but still statistically significant (Column 1). The logit (BC) model 
yields an effect of a one-year increase in average age on the odds of a yes vote of $3.8 \%$ (2). ${ }^{14}$ This is somewhat larger than the $(1.06 / 36.85=) 2.9 \%$ effect implied by the OLS reference model at the mean of the distribution of yes votes (Table 2, Column 3). Controlling for turnout hardly affects the estimated age effect (Column 3). This is the expected result given that the conditional correlation between turnout and average age is low (Table 2, Column 5). Using the gravity-based measure of expected changes in travel times instead of a simple straight-line distance from Stuttgart to capture the expected accessibility changes has a moderate effect on the age effect (Column 4). The explanatory power of this model is notably lower than that of the model using the straight-line distance measure. Possibly, voters had imperfect information regarding the expected accessibility changes, or distance from Stuttgart 21 affects the voting outcomes through channels other than expected accessibility gains. ${ }^{15}$ The age effect remains similarly unchanged if we allow for a non-linear effect of proximity to Stuttgart by means of 10 -km distance bins (Column 5). An examination of the 10 -km distance-bin effects reveals an approximately linear distance effect (conditional on other factors), confirming the parametric baseline model (see Figure A5 in Appendix I). Finally, we find qualitatively consistent age effects when using the share of elderly (65 years and older) among the electorate as an alternative age-related explanatory variable.

\section{[TAB 3 ABOUT HERE]}

Table 4 present 2SLS estimates of the age effect on opposition to Stuttgart 21. Each of the first four columns uses one of the four sets of IVs introduced in Section 2.2. Otherwise the models are identical to Table 2, Column 3. In Column (5), we use all IVs as the same time. In Column (6), we, in addition, control for turnout, therefore adding the turnout in the 2009 federal elections as an IV. All models control for contemporary industry composition (at the county level) to help with the validity of the instruments. Standard errors are clustered on counties.

The main takeaway is that the IV estimates of the age effect substantially exceed the OLS estimates. There are four not necessarily mutually exclusive candidate explanations to rationalize this pattern.

14 The logit model is identical to the OLS model in Equation (1) except for using $\log (P R C N T Y E S /[1-$ $P R C N T Y E S])$ as a dependent variable. To account for the grouped nature of the data, the observations are weighted by the inverse square root of the error term's variance. For a recent application, see Schulz \& Ursprung (2000).

15 For example, voters in such city regions as Freiburg, Heidelberg, Karlsruhe, or Mannheim, which are relatively farther from Stuttgart, may perceive the state capital Stuttgart as a competitor to their own local economies, and therefore be less likely to support a project that would strengthen it. 
First, the OLS estimates (with preferred controls) may suffer from included variable bias. Second, the OLS estimate may suffer from omitted variable bias due to an unobserved variable that is positively correlated with the outcome and negatively correlated with age, or vice versa. Third, the IVs may not be excludable and capture an omitted variable that is positively or negatively correlated with the both outcome and age. Fourth, there is heterogeneity in the effect of age on the outcome across municipalities and the IVs give internally valid causal estimates of the age effect that are not representative for the study area, an external validity problem.

Since even the unconditional OLS age effect is smaller than the smallest IV estimate in Table 4, the first explanation is insufficient. The second, unfortunately, is impossible to test empirically. As for the third, we have found some empirical support for the assumption that the geology and WWII destruction IVs predict economic outcomes in the past, but not today. Yet, it is these IVs that yield the largest estimates of the age effect. Finally, we find some support for the fourth explanation. If we allow for heterogeneity in the age effect by means of a full set of interaction terms between age and all covariates in a given set of controls, we find that the OLS estimates and the IV estimates are much closer together when we compute the age effect of a municipality with mean characteristics. Moreover, the difference between OLS and IV estimates computed for a municipality with mean characteristics shrinks as we allow for more dimensions of heterogeneity and the estimated marginal effects refer to more comparable municipalities. In this context, it is important to note that the heterogeneity in the age effect is quite large, at a coefficient of variation of about one (both for the OLS and IV estimates). Thus, it seems generally possible that the IV estimates differ from the OLS estimates because they are not externally valid. Thus, for the quantitative evaluation presented in the next sub-section, we choose to proceed with the more conservative OLS estimates. The analysis of heterogeneity in age effects in the OLS and IV is discussed in more detail in Appendix I, Section 9. There we also discuss some collateral findings from the analysis that connect to related literatures.

\subsection{Counterfactual simulation of the effects of population ageing}

To place the estimated age effects in the Stuttgart 21 referendum in the context of population ageing, we conduct a back-of-the-envelope simulation in the spirit of Poterba (1998). We combine our estimates with a recent population projection to answer the question of how the referendum outcome would differ were it held in the future. We consider fifteen combinations of (five) estimated age effects and (three) population projections. When using the estimated age effect conditional on distance from Stuttgart 21 exclusively (Table 2, Column 1), we implicitly assume that all other covariates are endogenous and will change as the population ages. In contrast, when using our three distinct sets of 
controls (Table 2, Columns 2-4), we assume that the population ages under the ceteris paribus assumption. Our fifth and most conservative estimate is from the WLS model in Table 3, Column (1). For population ageing, we refer to a reference, an optimistic, and a pessimistic scenario, which we all take from an official report published by the federal statistical office (Statistisches Bundesamt, 2009). ${ }^{16}$ According to the reference scenario, the average age of the German population will increase by seven years from 43.4 in 2011 to 50.4 years in $2060 .{ }^{17}$ The average age of the adult population (electorate), on which our analysis is based, will increase from 50.6 years in 2011 to 57.1 years in 2060.18

Our counterfactual simulations of the effect of population ageing on the share of yes votes in the Stuttgart 21 referendum are summarized in Figure 3. We start from the 2011 share of yes votes of 41.1 percent. For each subsequent year, we increase this share by the product of the expected change in the average age of the adult population relative to 2011 and the estimate of the marginal effect of age on the share of yes votes in the Stuttgart 21 referendum. ${ }^{19}$ Common to all scenarios, the counterfactual share of yes votes increases with time, with the rate of increase decreasing from the 2030s onwards. Holding other factors constant, the share of yes votes in the reference scenarios (thick black lines) will increase by 2.6 (age effects based on Column (4) of Table 2) to 5.7 (Column (2) of Table 2) percentage points over 20 years, a sizable magnitude given that referendums are often relatively narrowly decided (Dehring et al., 2008). After four decades, the effect of population would be large enough to lead to the rejection of the project in four out of the fifteen scenarios considered. Combining the most pessimistic (rapid ageing) population projection with the largest estimated age effect (only controlling for distance from Stuttgart 21), the implication is that the project would have been rejected as early as in 2037. Taking into account the margins of statistical uncertainty, a rejection cannot be ruled out at conventional confidence levels (95\%) from as early as 2030 onwards.

${ }^{16}$ In notations of the federal statistical office, we make use of the projections variant V1-W1 (reference), variant V2-W3 (optimistic), and variant V6-W1 (pessimistic).

17 The variant1-w1 scenario (middle population, lower limit) is based on the assumptions of (i) an increase in life expectancy of 8 years for newly born males and 7 years for females by 2060, (ii) a roughly constant birth rate of 1.4 children/woman, and (iii) an annual net migration of 100,000 persons starting in 2014.

18 Since the federal statistical office publishes the population projection by one-year age bins, the computation of the average age of the adult population (18 years and older) is straightforward.

19 For any given year $t$, the counterfactual voting outcome is $\widehat{V}_{t}=V_{2011}+\hat{\beta}\left(\overline{A G E}_{t}-\overline{A G E}_{2011}\right)$, were $V_{2011}$ is the percent of yes votes in the 2011 referendum, $\hat{\beta}$ is our estimate of the age effect, $\bar{A} G E_{2011}$ is the average age of the adult population in 2011, and $\overline{A G E}_{t}$ is the respective projection for year $t$. 
Given the assumptions regarding the absence of cohort effects made, the numbers presented in this section need to be interpreted with care. The main takeaway is that our estimated age effects and the expected population ageing together appear to be large enough to be quantitatively meaningful. Population ageing, thus, could potentially influence direct democracy outcomes in the foreseeable future.

\section{[FIG 3 ABOUT HERE]}

\section{Quantitative survey}

As with every case study, we are naturally concerned with the generalizability of our findings and the mechanisms that drive our results. Is lifecycle-specific voting a general phenomenon in direct democracy or is it specific to topics where the net present value differs strongly across age groups? Is the age effect in the Stuttgart 21 referendum likely attributable to attitudes towards environmental protection or urban redevelopment that could be correlated with age? More generally, can generic skepticism towards modernization, e.g. due to habituation (Samuelson and Zeckhauser, 1988), explain why opposition to reform projects increases in age, or do we require maximization of expected individual utility (Messner and Polborn, 2004) as an explicit argument to rationalize existing evidence? To address these questions and to provide a synthesis of the state of knowledge, this section provides the first quantitative summary of evidence on age-specific voting patterns in public referendums.

\subsection{Literature review}

In collecting the evidence base for our quantitative literature review, we follow standard best-practice approaches of meta-analytic research, as reviewed by Stanley (2001).20 We include studies that empirically analyze the determinants of voting decisions in public referendums and include at least one age-related variable as a covariate. ${ }^{21}$ To maximize the evidence base, we consider analyses of grouped data, typically at the level of voting precincts, and post-referendum surveys that inquire about voters' decisions in actual referendums. Depending on the research design, the age-related variable can take various forms, such as the actual age of an interviewee, average age of the population living in a voting precinct, or the share of an age group (e.g., 60 and older). Further, to prevent

\footnotetext{
20 Recent examples of meta-analyses in economics include studies by Eckel and Füllbrunn (2015), Melo (2013), and Nitsch (2005).

${ }^{21}$ In one of the included studies, the analysis was descriptive rather than econometric (Pelinka, 1983).
} 
publication bias, we consider studies that were published as edited book chapters, in refereed journals, or in academic working paper series.

In searching for empirical analyses of public referendums, we pursue a three-step strategy. We begin with the standard practice of a keyword search in academic databases (EconLit, Web of Science, and Google Scholar) and specialist research institute working paper series (NBER, CEPR, CESIfo, and IZA). Because analyses of public referendums usually do not focus on age effects, searching for age-related terms (e.g., age, generation, and intergenerational conflict) did not prove useful. Instead, we used key terms, such as "voting analysis", "referendum analysis", "precinct analysis", "referendum + analysis", "vote + infrastructure", and "referendum + empirical" to identify as broad as possible a base of empirical analyses of referendums. This search yielded 33 studies, which, upon a first inspection, satisfied the minimum standards of academic rigor and were suitable for our meta-analyses. Starting from the identified studies, we conducted both an upstream and downstream analysis of citation trees, which increased the set of candidate studies to 53. In the third step, we asked colleagues working in related fields to recommend empirical analyses of referendums. This added a further 16 studies to the list, resulting in 69 potential studies.

After eliminating duplications (working papers and academic publications), studies that were of subordinated relevance for the purposes of this review (e.g., theoretical work), or generally suitable analyses without age-related covariates, we were left with a pool of 33 studies, which we summarize in Table 5. Because several studies contain more than one referendum analysis, the total number of referendum analyses amounts to 112 . We approximate the total votes covered by these analyses as about 400 million (see Appendix II, Section 3 for details). Because the existing referendum analyses typically do not focus on age as a primary determinant of voting decisions, we are more likely to miss some relevant evidence in this study than in a typical meta-analysis reviewing a self-contained literature strand. On the positive side, the same fact also makes it is less likely that there is publication bias in favor of statistical significance or a certain direction of the age effect.

Most referendum topics relate to school spending, environmental legislation, energy policies, European integration, transport, and, perhaps somewhat surprisingly, sports facilities. Reflecting the variety of topics, popular publication outlets are journals related to environmental, political, public, and urban economics. More than three quarters of the studies analyze grouped data at the voting precinct level, while the remaining studies collected individual data in post-referendum surveys. Over time, the analysis of grouped data has become more popular, likely reflecting the increasing availability of data for relatively small spatial units. All studies analyze referendums held either in the US or EU 
(and associated countries), with the US accounting for the larger share (20 vs. 13 studies). We provide further detail on the referendums in those studies, as well as the information that we extract, in Table A1 of Appendix II.

\section{[TAB 5 ABOUT HERE]}

\subsection{Lifecycle attitudes}

Coding the relevant characteristics of the considered studies is a critical issue in a quantitative literature review (Hunter and Schmidt, 1990). In the present study, encoding attitudes in a way that is amenable to a pooled analysis is particularly challenging, since the definition of an individualistic lifecycle attitude depends on the topic, context, and specific question asked in a referendum. To categorize the lifecycle pattern in a referendum, we proceed as follows. If the age effect revealed in a referendum analysis is qualitatively consistent with individual expected utility maximization, as well as statistically significant, we code the lifecycle attitude as individualistic. If a referendum analysis yields a statistically insignificant age effect, we code the attitude as neutral. If the age effect is statistically significant and points toward the opposite direction of what we would code as individualistic, we code the attitude as collectivistic. The terms individualistic and collectivistic are borrowed from psychology literature, which analyzes the extent to which individuals give priority to personal (individualistic) or group (collectivistic) goals (Oyserman et al., 2002; Triandis, 1995).

To give some examples, as voters with individualistic attitudes age, they should be less concerned about housing affordability and job creation (Fischel, 1979) and prefer spending on health services over state schools (Rubinfeld, 1977). Similarly, the priority given to investments in durable capital stock, such as infrastructure or measures that seek to mitigate climate change will decrease. In Table 6, we summarize how we define an individualistic lifecycle attitude for a number of categories into which the analyzed referendums can be grouped. In Table A1 in Appendix II, we document how we coded the lifecycle attitudes in each of the referendums considered, accompanied by a rationale for every special case.

\section{[TAB 6 ABOUT HERE]}

Resistance to reform projects with positive welfare effects is often referred to as a status-quo bias in political economy literature (Fernandez and Rodrik, 1991; Kahneman et al., 1991). Messner and Polborn (2004) argue that this resistance increases as voters age because the individual expected utility decreases. However, risk-aversion likely increases in age (Mather et al., 2012) and status-quo 
bias could increase in age simply by habituation (Samuelson and Zeckhauser, 1988). To distinguish these alternative determinants of lifecycle-specific voting, we also encode if an increase in voter age is associated with a greater support of the status quo or a change in legislation.

\subsection{Results}

Figure 4 summarizes the distribution of the encoded attitudes separately for referendums held in Europe (EU) and in the US. In about $49 \%$ of the considered referendums, the lifecycle attitude is individualistic, i.e. voters give preference to the maximization of the expected utility of their own generation. This percentage is somewhat larger for the US (58\%) than for EU (43\%). The opposite is true (collectivistic attitude) in just $8 \%$ of the cases (US and EU), with the remaining referendums showing no significant age effect. Support of the status-quo increases in age in $41 \%$ of the referendums, again, slightly more often in the US than in EU (49\% vs. 36\%, respectively). Notably, there are also a number of referendums where the lifecycle attitude is individualistic, but increases in age are associated with greater support for change, suggesting that age-related status quo bias is not a sufficient explanation for lifecycle-specific voting.

\section{[FIG 4 ABOUT HERE]}

In Figure 5, we illustrate the distribution of lifecycle attitudes by referendum categories. The support of green energy reforms decreased in voter age in all nine referendums. Another impressive insight is that in none of the 16 analyzed referendums on school spending (14 of which were conducted in the US), did the support for spending on schools increase in voter age. In only four cases, there were no significant effects found, while the remaining 12 studies showed evidence of individualistic attitudes. Interestingly, the collective body of evidence emerging from referendum analyses provides a clearer pattern than the literature that has correlated expenditures on public schools with demographic structures at different spatial levels, which has provided mixed results (Harris et al., 2001; Ladd and Murray, 2001; Poterba, 1998). Similarly, clear tendencies of individualistic voting are evident in referendums on environmental protection, health services, and welfare policies. Moreover, individualistic voting is relatively frequent among referendums on transportation and other infrastructure (e.g., water supply), but only to a limited extent among referendums on urban development (e.g., urban growth boundaries). Thus, attitudes towards environmental protectionism and urban development do not appear like a likely driver of the age effects found in our case study. For the remaining categories, there is little evidence of lifecycle patterns in voting. As an example, lifecycle 
attitudes are neutral in all four referendums in the category "moralities", which contains referendums on abortion policy, animal testing, and equal opportunity policies. This is reassuring because an intergenerational conflict in these cases is less obvious than in other categories.

\section{[FIG 5 ABOUT HERE]}

In Table 7 we provide a test of whether lifecycle attitudes tend to lean towards individualistic or collectivistic within certain categories, controlling for some other factors. In Column (1) of Table 7, we regress a categorical index, taking the value of $-1 / 0 /+1$ for collectivistic / neutral / individualistic attitudes, against dummy variables denoting each of the referendum categories; a dummy variable denoting survey (as opposed to grouped precinct) data that controls for survey bias (Funk, 2016); whether a study was recommended to us by colleagues; and a publication year trend variable (scaled to have a zero value in 2000). Because we omit the constant, the category coefficients can be interpreted as conditional means of the dependent variable within categories. We add a dummy controlling for whether a referendum was held in the US in (2) and country fixed effects in (3). To avoid that results are driven by individual studies containing multiple referendum analyses we weight referendums such that every study (not referendum) receives the same weight in (4). In (5) we restrict the referendum sample to cases where the definition of an individualistic lifecycle attitude is particularly uncontroversial (see Appendix II, Section 4 for a discussion). In Column (6), we control for the age effect on status-quo orientation using a categorical index taking the value of $-1 / 0 /+1$ for support of change / insignificant age effect / support of status quo before we use that variable as depended variable in Column (7).

In line with Figure 5, we find that the conditional means of our lifecycle attitude variable lean significantly toward individualistic for Energy, Environment, Health services, Integration, School spending, and Welfare across a variety of models in Table 7. Conditional on controlling for composition, the US effect suggested by Figure 4 is not statistically significant, nor do country fixed effects considerably alter the results. Notably, lifecycle attitudes lean significantly towards individualistic for Transport \& infrastructure once we restrict the sample to the uncontroversial cases which involve major investments into durable capital. In contrast, the lifecycle attitude on environmental protection becomes neutral in this restricted sample.

As expected, the age effect on the support for the status quo is a strong predictor of the lifecycle attitude variable. This is in line with an unconditional polychoric correlation of 0.71 (standard error $=0.08$ ) between the two variables. However, the conditional means within referendum categories 
are fairly robust to controlling for the status-quo-related age effects. Unlike for individualistic attitudes, we do not find a significant association between age and status-quo orientation for referendums on health services and welfare policies (Column 7). These results substantiate the impression that the strong tendency of individualistic voting in a number of categories is difficult to rationalize with status quo bias alone.

\section{[TAB 7 ABOUT HERE]}

We present a number of additional models not reported here for the sake of brevity in Appendix II, Section 5. We estimate the baseline model separately for US and European referendums. We use the unambiguous sample in a weighted version and a version in which we control for status quo preferences. We also estimate status quo models using the unambiguous sample, a weighted version, and a version controlling for whether a referendum took place in the US. The results substantiate the interpretations above.

\section{Conclusion}

This paper analyzes the effect of voter age on voting decisions in public polls, such as initiatives and referendums, to understand the potential implications of population ageing for direct democracy. To this end, we provide a case study of the Stuttgart 21 referendum on one of the largest infrastructure projects in Germany and a first quantitative review of the literature focusing explicitly on age-specific voting behavior in public referendums. The evidence collected suggests that intergenerational conflicts exist where the expected net present value of reform projects differs particularly strongly across generations.

A tentative conclusion from our analysis is that, as population ageing progresses, investment-like reform projects that require initial expenditures and pay off in the long run may become more difficult to realize. However, a limitation of our case-study analysis that is shared with the wider evidence base is that the effects of individual ageing and affiliation to different birth cohorts cannot be distinguished in a cross-sectional referendum analysis. An important challenge that lies ahead of the research field is to separately identify age and cohort effect. To the extent that a genuine age effect can be substantiated by evidence, it will become increasingly important to address intergenerational differences in expected net benefits to obtain support for welfare-enhancing projects with long-term benefits in ageing societies. Possible avenues include passing on the costs to future generations through debt financing (Bowen et al., 1960) or giving a stronger political voice to children, either by 
lowering the voting age (Chan and Clayton, 2006) or by having parents vote on their behalf (Demeny, 1986). Alternatively, decisions can be based on social cost benefit analyses instead of referendums (Osborne and Turner, 2010).

\section{Literature}

Abel, Andrew B. (2001). Will Bequests Attenuate the Predicted Meltdown in Stock Prices When Baby Boomers Retire? Review of Economics and Statistics, 83(4), 589-595.

Acemoglu, Daron, \& Johnson, Simon. (2007). Disease and Development: The Effect of Life Expectancy on Economic Growth. Journal of Political Economy, 115(6), 925-985.

Ahlfeldt, Gabriel M., \& Maennig, Wolfgang. (2015). Homevoters vs. leasevoters: A spatial analysis of airport effects. Journal of Urban Economics, 87, 85-99.

Ahlfeldt, Gabriel M., Moeller, Kristoffer, Waights, Sevrin, \& Wendland, Nicolai. (2017). Game of zones: The political economy of conservation areas. Economic Journal, 127, F421-F445.

Ahlfeldt, Gabriel M., Redding, Stephan J., Sturm, Daniel M., \& Wolf, Nikolaus. (2015). The Economics of Density: Evidence from the Berlin Wall. Econometrica, 83(6), 2127-2189.

Angrist, Joshua D., \& Pischke, Jörn-Steffen. (2009). Mostly Harmless Econometrics: An Empiricist's Companion. Princeton, New Jersey: Princeton University Press.

Baum-Snow, Nathaniel. (2007). Did Highways Cause Suburbanization? The Quarterly Journal of Economics, 122(2), 775-805.

Bowen, William G., Davis, Richard G., \& Kopf, David H. (1960). The Public Debt: A Burden on Future Generations? The American Economic Review, 50(4), 701-706.

Brakman, Steven, Garretsen, Harry, \& Schramm, Marc. (2004). The strategic bombing of German cities during World War II and its impact on city growth. Journal of Economic Geography, 4(2), 201-218.

Breyer, Friedrich, \& Stolte, Klaus. (2001). Demographic change, endogenous labor supply and the political feasibility of pension reform. Journal of Population Economics, 14(3), 409-424.

Brunner, Eric, \& Balsdon, Ed. (2004). Intergenerational conflict and the political economy of school spending. Journal of Urban Economics, 56(2), 369-388.

Brunner, Eric, Sonstelie, Jon, \& Thayer, Mark. (2001). Capitalization and the Voucher: An Analysis of Precinct Returns from California's Proposition 174. Journal of Urban Economics, 50(3), 517 536.

Chan, Tak Wing, \& Clayton, Matthew. (2006). Should the Voting Age be Lowered to Sixteen? Normative and Empirical Considerations. Political Studies, 54(3), 533-558.

Coates, Dennis, \& Humphreys, Brad R. (2006). Proximity benefits and voting on stadium and arena subsidies. Journal of Urban Economics, 59(2), 285-299.

Conley, T. G. (1999). GMM estimation with cross sectional dependence. Journal of Econometrics, 92(1), 1-45.

Deacon, R., \& Shapiro, P. (1975). Private Preference for Collective Goods Revealed Through Voting on Referenda. The American Economic Review, 65(5), 943-955.

Dehring, Carolyn A., Depken, Craig A., \& Ward, Michael R. (2008). A direct test of the homevoter hypothesis. Journal of Urban Economics, 64(1), 155-170.

Demange, Gabrielle, \& Laroque, Guy. (1999). Social Security and Demographic Shocks. Econometrica, 67(3), 527-542.

Demeny, P. (1986). Pronatalist Policies in Low-Fertility Countries: Patterns, Performance and Prospects. Population and Development Review, 12, 335-358.

Department for Transport. (2014). Transport Analysis Guidance (TAG) Unit A1.1 Cost-Benefit Analysis. Retrieved from https://www.gov.uk/transport-analysis-guidance-webtag

Duranton, Gilles, \& Turner, Matthew A. (2012). Urban Growth and Transportation. The Review of Economic Studies, 79(4), 1407-1440.

Eckel, Catherine C., \& Füllbrunn, Sascha C. (2015). Thar SHE Blows? Gender, Competition, and Bubbles in Experimental Asset Markets. American Economic Review, 105(2), 906-920.

Feinerman, Eli, Finkelshtain, Israel, \& Kan, Iddo. (2004). On A Political Solution to the NIMBY Conflict. American Economic Review, 94(1), 369-381. 
Feld, Lars P., \& Matsusaka, John G. (2003). Budget referendums and government spending: evidence from Swiss cantons. Journal of Public Economics, 87(12), 2703-2724.

Fernihough, Alan, O'Rourke, Kevin Hjortshøj. (2014). Coal and the European Industrial Revolution. NBER Working Paper 19802.

Fernandez, Raquel, \& Rodrik, Dani. (1991). Resistance to Reform: Status Quo Bias in the Presence of Individual-Specific Uncertainty. American Economic Review, 81(5), 1146-1155.

Fischel, William A. (1979). Determinants of voting on environmental quality: A study of a New Hampshire pulp mill referendum. Journal of Environmental Economics and Management, 6(2), 107-118.

Fischel, William A. (2001a). The Homevoter Hypothesis. Cambridge, MA: Harvard University Press.

Fischel, William A. (2001b). Why Are There NIMBYs? Land Economics, 77(1), 144-152.

Frey, Bruno S., Oberholzer-Gee, Felix, \& Eichenberger, Reiner. (1996). The old lady visits your backyard: A tale of morals and markets. Journal of Political Economy, 104(6), 1297.

Funk, Patricia. (2016). How Accurate are Surveyed Preferences for Public Policies? Evidence from a Unique Institutional Setup. Review of Economics and Statistics, forthcoming.

Gaigné, Carl, \& Thisse, Jacques-François. (2009). Aging and the future of cities. Journal of Regional Science, 49(4), 663-688.

Glaeser, Edward L., Kallal, Hedi D., Scheinkman, José A., \& Shleifer, Andrei. (1992). Growth in Cities. Journal of Political Economy, 100(6), 1126-1152.

Harris, Amy Rehder, Evans, William N., \& Schwab, Robert M. (2001). Education spending in an aging America. Journal of Public Economics, 81(3), 449-472.

Henderson, Vernon, Kuncoro, Ari, \& Turner, Matt. (1995). Industrial Development in Cities. Journal of Political Economy, 103(5), 1067-1090.

Holtz-Eakin, Douglas, Lovely, Mary E., \& Tosun, Mehmet S. (2004). Generational conflict, fiscal policy, and economic growth. Journal of Macroeconomics, 26(1), 1-23.

Hunter, John E. , \& Schmidt, Frank L. (1990). Methods of Meta-Analysis: Correcting Error and Bias in Research Findings. Newbury Park: Sage Publications.

Kahn, M. E., \& Matsusaka, J. G. (1997). Demand for Environmental Goods: Evidence from Voting Patterns on California Initiatives. The Journal of Law and Economics, 40(1), 137-173.

Kahneman, Daniel, Knetsch, Jack L., \& Thaler, Richard H. (1991). Anomalies: The Endowment Effect, Loss Aversion, and Status Quo Bias. Journal of Economic Perspectives, 5(1), 193-206.

Krosnick, Jon A., \& Alwin, Duane F. (1989). Aging and Susceptibility to Attitude Change. Journal of Personality and Social Psychology, 57(3), 416-425.

Kröger, Michael. (2010, 08.09.2010). Was für "Stuttgart 21" spricht - und was dagegen. Spiegel Online.

Krueger, Dirk, \& Ludwig, Alexander. (2007). On the consequences of demographic change for rates of returns to capital, and the distribution of wealth and welfare. Journal of Monetary Economics, 54(1), 49-87.

Kurbjuweit, Dirk. (2010). Der Wutbürger. Der Spiegel, 41, October 11, 26-27.

Ladd, Helen F., \& Murray, Sheila E. (2001). Intergenerational conflict reconsidered: county demographic structure and the demand for public education. Economics of Education Review, 20(4), 343-357.

Ladd, Helen F., \& Wilson, Julie B. (1983). Who supports tax limitations: Evidence from Massachusetts' proposition 21/2. Journal of Policy Analysis and Management, 2(2), 256-279.

Lawley, Chad, \& Furtan, Hartley. (2008). The political trade-off between environmental stringency and economic development in rural America. Journal of Regional Science, 48(3), 547-566.

Lumme, Christoph. (2010). Stuttgart 21: Warum die Rentner auf die Straße gehen. Westdeutsche Zeitung.

Mather, Mara, Mazar, Nina, Gorlick, Marissa A., Lighthall, Nichole R., Burgeno, Jessica, Schoeke, Andrej, \& Ariely, Dan. (2012). Risk preferences and aging: The "certainty effect" in older adults' decision making. Psychology and Aging, 27(4), 801-816.

Matsusaka, John G. (2004). For the Many or the Few: The Initiative, Public Policy, and the American Democracy. Chicago: University of Chicago Press.

Matsusaka, John G. (2005). Direct Democracy Works. Journal of Economic Perspectives, 19(2), 185206.

McCoy, Daire, Lyons, Sean, Morgenroth, Edgar, Palcic, Donal, \& Allen, Leonie. (2018). The impact of broadband and other infrastructure on the location of new business establishments. Journal of Regional Science, online first, n/a-n/a. 
Melo, Patricia C., Graham, Daniel J., \& Brage-Ardao, Ruben. (2013). The productivity of transport infrastructure investment: A meta-analysis of empirical evidence. Regional Science and Urban Economics, 43(5), 695-706.

Messner, Matthias, \& Polborn, Mattias K. (2004). Voting on Majority Rules. The Review of Economic Studies, 71(1), 115-132.

Mohammed, Saif I., Williamson, Jeffrey G. (2004). Freight rates and productivity gains in British tramp shipping 1869-1950. Explorations in Economic History, 41, 172-203.

Nitsch, Volker. (2005). Zipf zipped. Journal of Urban Economics, 57(1), 86-100.

Osborne, Martin J., \& Turner, Matthew A. (2010). Cost Benefit Analysis versus Referenda. Journal of Political Economy, 118(11), 156-187.

Oyserman, Daphna, Coon, Heather M., \& Kemmelmeier, Markus. (2002). Rethinking Individualism and Collectivism: Evaluation of Theoretical Assumptions and Meta-Analyses. Psychological Bulletin, 128(1), 3-72.

Pelinka, Anton. (1983). The nuclear power referendum in Austria. Electoral Studies, 2(3), 253-261.

Poterba, James M. (1998). Demographic Change, Intergenerational Linkages, and Public Education. The American Economic Review Papers and Proceedings, 88(2), 315-320.

Poterba, James M. (2001). Demographic Structure and Asset Returns. The Review of Economics and Statistics, 83(4), 565-584.

Reimann, Anja. (2010). Rebellische Rentner - Aufstand der Silberköpfe. Spiegel Online, October 17. Retrieved from http://www.spiegel.de/politik/deutschland/rebellische-rentner-aufstandder-silberkoepfe-a-723053.html

Rubinfeld, Daniel L. (1977). Voting in a local school election: A micro analysis. The Review of Economics and Statistics, 59(1), 30-42.

Samuelson, William, \& Zeckhauser, Richard. (1988). Status quo bias in decision making. Journal of Risk and Uncertainty, 1(1), 7-59.

Schulze, Gunther G., \& Ursprung, Heinrich W. (2000). La donna e mobile -- or is she? Voter preferences and public support for the performing arts. Public Choice, 102(1/2), 131-149.

Shuster, Simon. (2016). The U.K.'s Old Decided for the Young in the Brexit Vote. Time, June 24, 2016.

SMA und Partner AG. (2010). Stuttgart 21 und Kopfbahnhof 21: Vergleichende Analyse der Reisezeiten. Zurich.

Stanley, T. D. (2001). Wheat from Chaff: Meta-analysis as Quantitative Literature Review. Journal of Economic Perspectives, 15(3), 131-150.

Statistisches Bundesamt. (2009). Bevölkerung Deutschlands bis 2060 12. koordinierte Bevölkerungsvorausberechung. Wiesbaden.

Stuckenbrock, Uwe. (2013). Das Projekt "Stuttgart 21" im zeitlichen Überblick. In F. Brettschneider \& W. Schuster (Eds.), Stuttgart 21 Ein Großprojekt zwischen Protest und Akzeptanz (pp. 1576). Wiesbaden: Springer VS.Triandis, Harry Charalambos. (1995). Individualism \& collectivism. New directions in social psychology. Boulder, CO, US: Westview Press.

United Nations. (2013). World Population Ageing. New York: United Nations.

Verkehrswissenschaftliches Institut Stuttgart, \& Intraplan Consult. (2006). Nutzen-KostenUntersuchung ÖPNV-Maßnahmen Stuttgart 21. Stuttgart: Ministry of the interior, BadenWürtemberg.

Vlachos, Jonas. (2004). Who wants political integration?: Evidence from the Swedish EU-membership referendum. Journal of Public Economics, 88(7-8), 1589-1604.

Wagschal, Uwe. (2013). Die Volksabstimmung zu Stuttgart 21 - ein direktdemokratisches Lehrstück? In U. Wagschal, U. Eith, \& M. Wehner (Eds.), Der historische Machtwechsel: Grünrot in Baden-Würtemberg (pp. 181-205). Berlin: Nomos.

Winkelmann, U. (2013). Berufspendler in Baden-Württemberg. Statistisches Monatsheft BadenWürttemberg, November 2013, 25-29. 


\section{Figures}

Fig. 1. Opposition to Stuttgart 21 project (share of yes votes)

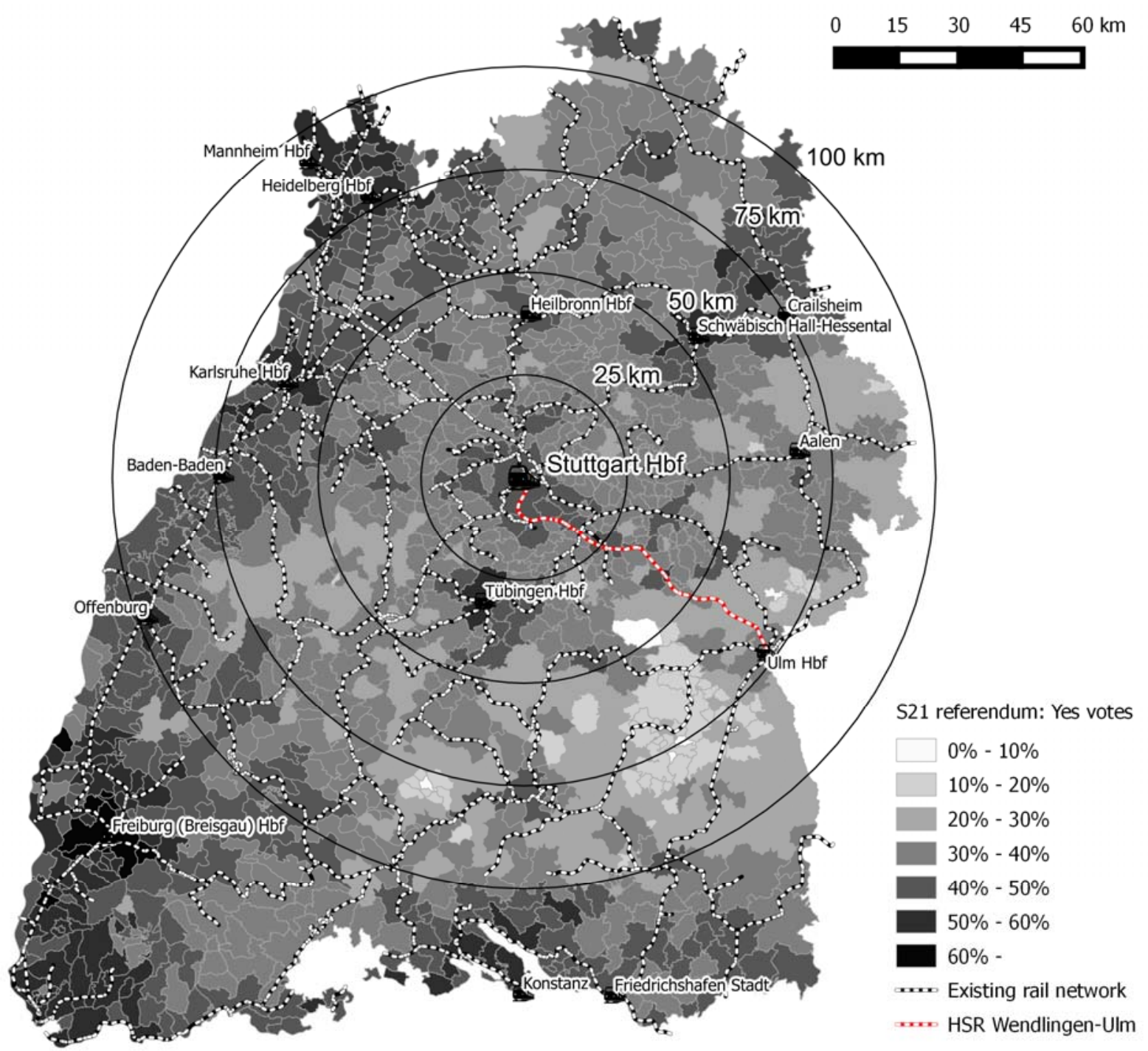

Notes: Own illustration based on DLM250-Geodata by the Federal Agency for Cartography and Geodesy. Geographic unit is municipalities. 
Fig. 2. Correlation between share of yes votes and average age across municipalities
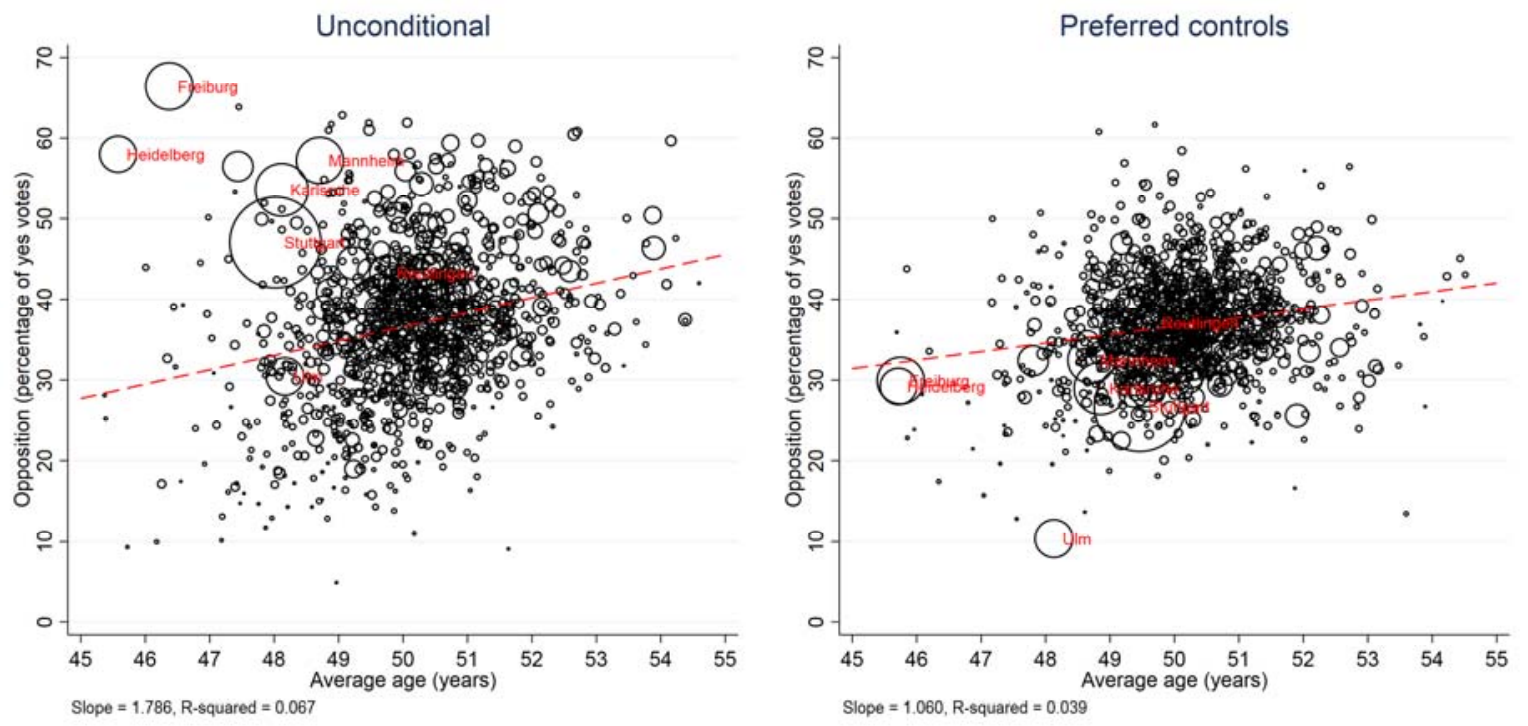

Notes: Average age refers to the adult population (electorate). The conditional correlation is based on the residuals of a regression of the share of yes votes against all covariates but age, and the residuals of a regression of age against the same covariates. The mean share of yes votes and mean age are added to the respective residuals to keep a consistent scale. Preferred controls include the household income, the educational status, population density, unemployment rate, homeownership, the number of registered cars per capita, and the county-level shares of the secondary and tertiary sectors at total employment. A handful of outliers, in terms of age, is not displayed, to improve the presentation. The dashed lines are linear fits to all observations (including outliers), marker size is proportionate to the absolute number of votes, and largest cities are labelled. 
Fig. 3. Counterfactual Stuttgart 21 voting outcomes

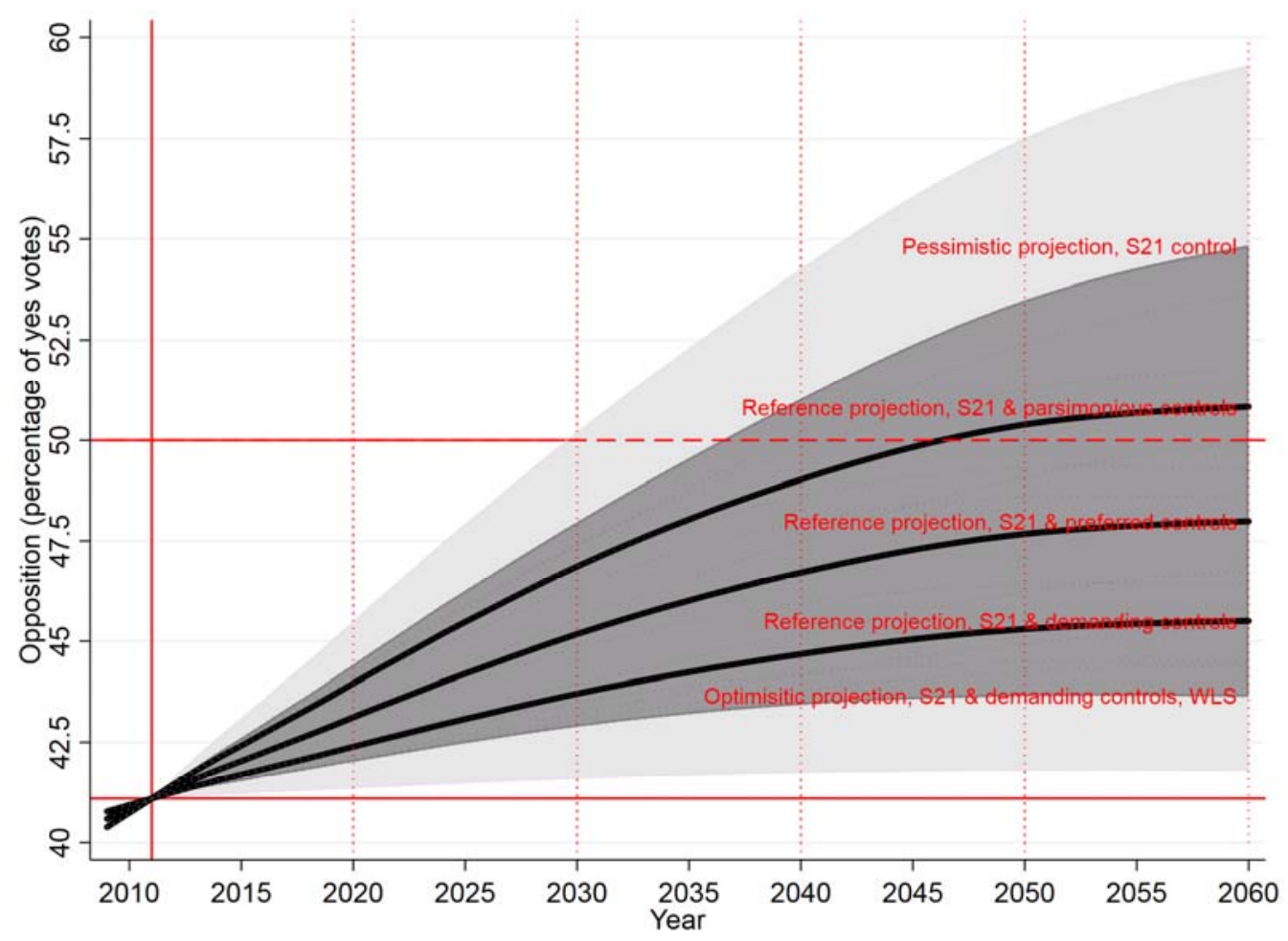

Notes: Own illustration based on estimates from Table 2, Columns (2-4) and Table 3, Column (1), and the scenarios V1-W1 (reference), V3-W2 (optimistic), and V6-W1 (pessimistic) published in the $12^{\text {th }}$ coordinated population projection by the German Federal Statistical Office (Statistisches Bundesamt, 2009). The dark shaded area is the envelope of all counterfactual voting outcomes for different combinations of estimated age effects and population projections (the light dotted rays). The light shaded area is the envelope of all $95 \%$ confidence intervals. 
Fig. 4. Lifecycle attitudes and age effects on status-quo preference in referendums

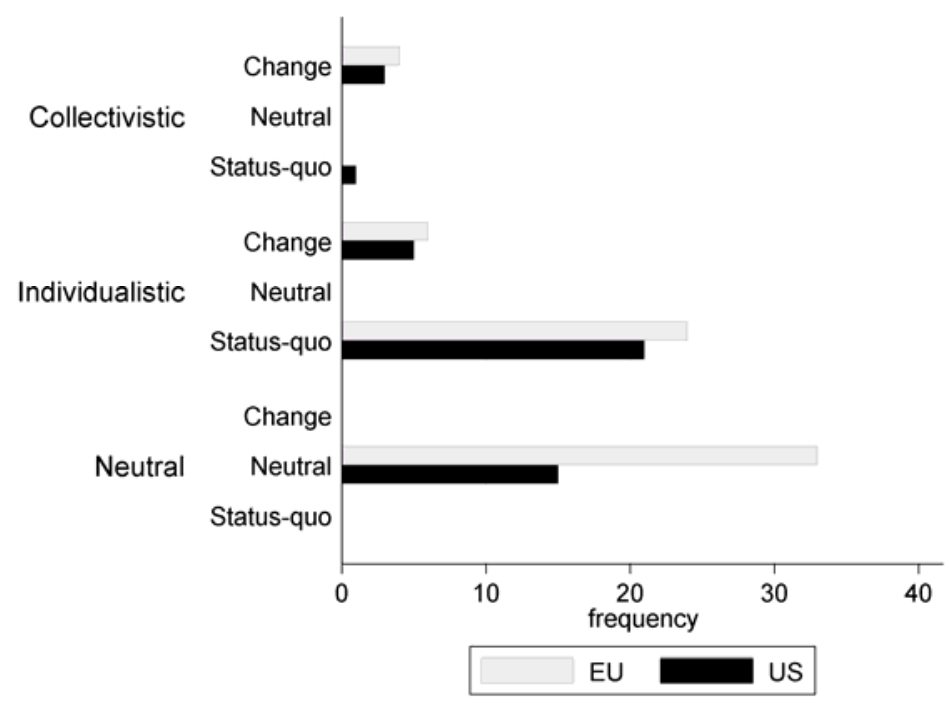

Notes: Lifecyle attitude is individualistic, if the age effect is in line with the definition in Table 6 as well as statistically significant and collectivistic, if the age effect is in the opposite direction and statistically significant. Further, the age effect is encoded as change (status-quo) if the age effect is significant and points in the direction of changing (maintaining) the legal status quo. The age effect is encoded as neutral (both categories) if insignificant. 
Fig. 5. Lifecycle attitudes by category

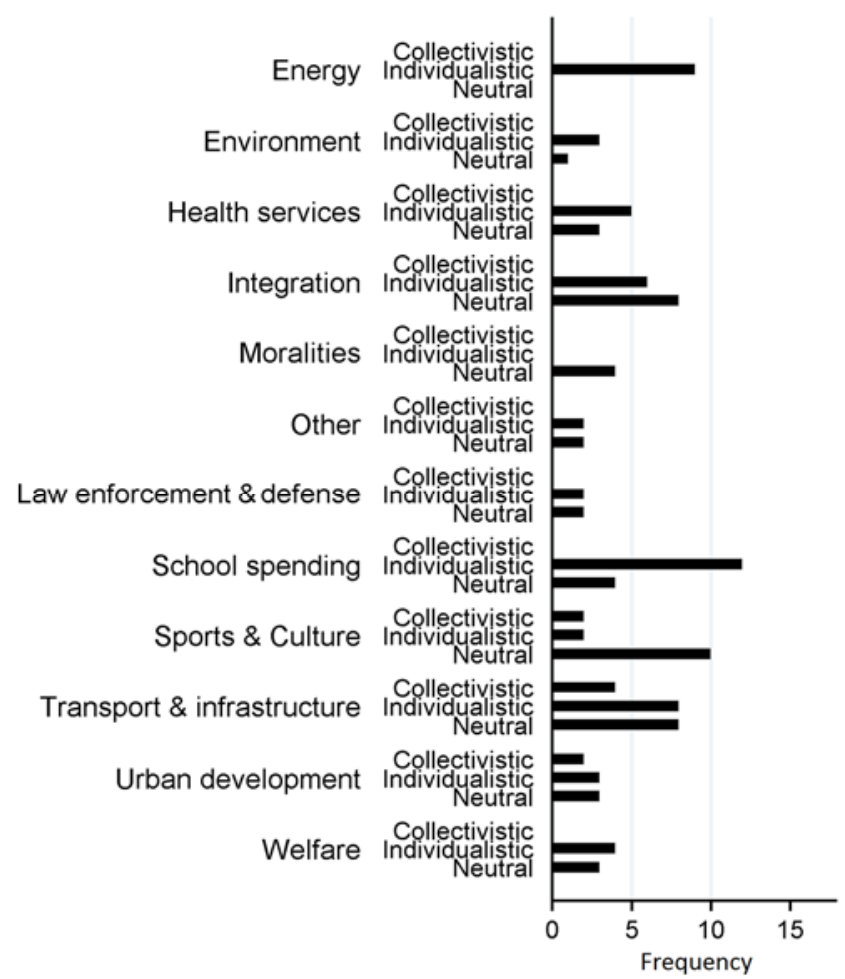

Notes: Lifecycle attitude is individualistic, if the age effect in line with the definition in Table 6, as well as statistically significant; collectivistic if the age effect is in the opposite direction and statistically significant; and neutral if the age effect is insignificant. "Other" includes referendums on liberalization of agriculture, direct democracy, and foreign aid. 


\section{Tables}

Tab. 1. Descriptive statistics

\begin{tabular}{|c|c|c|c|c|c|}
\hline Variable & Description & Mean & S.D. & Min. & Max. \\
\hline \multicolumn{6}{|l|}{ Dependent variables } \\
\hline Yes & Yes votes in Stuttgart 21 referendum (\%) & 36.85 & 9.76 & 4.90 & 66.45 \\
\hline Turnout & Voter turnout in Stuttgart 21 referendum (\%) & 48.81 & 8.87 & 25.74 & 80.51 \\
\hline \multicolumn{6}{|l|}{ Age variables } \\
\hline Average age & Average age of adult population (years) & 50.12 & 1.41 & 44.10 & 59.25 \\
\hline Age $>65$ & Share of adult population aged above 65 & 23.12 & 3.11 & 13.84 & 44.36 \\
\hline \multicolumn{6}{|l|}{ Spatial variables } \\
\hline Distance to Stuttgart & Distance to central Stuttgart $(\mathrm{km})$ & 74.64 & 37.44 & 0.00 & 175.12 \\
\hline Delta travel time & Average change in commuting time (minutes) & -0.92 & 2.17 & -24.71 & 8.70 \\
\hline \multicolumn{6}{|l|}{ Parsimonious controls } \\
\hline Degree share & Share of workforce holding an academic degree (\%) & 12.07 & 3.35 & 4.72 & 34.14 \\
\hline Income & Total taxable income / population (1000 €) & 17.29 & 2.44 & 11.33 & 34.07 \\
\hline Density & Population density (100 people per $\mathrm{km}^{2}$ ) & 3.14 & 3.28 & 0.18 & 28.26 \\
\hline \multicolumn{6}{|c|}{ Preferred controls (additional variables) } \\
\hline Male & Share of male at adult population (\%) & 49.09 & 1.34 & 34.00 & 59.21 \\
\hline Unemployment & Registered unemployed / workforce $(15 \leq$ age < 65) (\%) & 2.49 & 0.83 & 0.53 & 6.43 \\
\hline Homeowner & Share of owner-occupied dwellings (\%) & 64.17 & 9.33 & 26.61 & 91.78 \\
\hline Car ownership & Private cars per capita (x100) & 54.46 & 4.51 & 0.34 & 70.07 \\
\hline Secondary sector 2011 & Share of secondary sector of employment in 2011 & 33.12 & 7.86 & 13.06 & 50.40 \\
\hline Tertiary sector 2011 & Share of tertiary sector of employment in 2011 & 65.52 & 8.33 & 48.80 & 86.94 \\
\hline \multicolumn{6}{|c|}{ Demanding controls (additional variables) } \\
\hline Baden & Dummy for location in Baden region $(0,1)$ & 0.46 & 0.50 & 0 & 1 \\
\hline Conservatives & Share of conservative party votes (\%) & 37.41 & 6.09 & 21.47 & 66.96 \\
\hline Greens & Share of green party votes (\%) & 11.87 & 3.23 & 1.39 & 27.25 \\
\hline
\end{tabular}

Notes: The descriptive statistics for all variables are shown in the original, non-centered scale. All variables, except political variables, are observed in 2011. 
Tab. 2. Determinants of opposition to Stuttgart 21: Baseline models

\begin{tabular}{|c|c|c|c|c|c|c|}
\hline & (1) & (2) & (3) & (4) & (5) & (6) \\
\hline & $\begin{array}{l}\text { Share yes } \\
\text { votes (\%) }\end{array}$ & $\begin{array}{l}\text { Share yes } \\
\text { votes (\%) }\end{array}$ & $\begin{array}{l}\text { Share yes } \\
\text { votes }(\%)\end{array}$ & $\begin{array}{l}\text { Share yes } \\
\text { votes (\%) }\end{array}$ & Turnout (\%) & Turnout (\%) \\
\hline Average age (years) & $\begin{array}{l}1.641 \\
(0.273)^{* * *} \\
{[0.314]^{* * *}}\end{array}$ & $\begin{array}{l}1.498 \\
(0.213)^{* * *} \\
{[0.239]^{* * *}}\end{array}$ & $\begin{array}{l}1.060 \\
(0.190)^{* * *} \\
{[0.224]^{* * *}}\end{array}$ & $\begin{array}{l}0.677 \\
(0.133)^{* * *} \\
{[0.154]^{* * *}}\end{array}$ & $\begin{array}{l}0.014 \\
(0.165) \\
{[0.230]}\end{array}$ & $\begin{array}{l}0.263 \\
(0.137)^{*} \\
{[0.174]}\end{array}$ \\
\hline Distance from & 0.091 & 0.123 & 0.109 & 0.075 & -0.146 & -0.120 \\
\hline Stuttgart (km) & $\begin{array}{l}(0.00656)^{* * *} \\
{[0.0161]^{* * *}}\end{array}$ & $\begin{array}{l}(0.00585)^{* * *} \\
{[0.0112]^{* * *}}\end{array}$ & $\begin{array}{l}(0.00674)^{* * *} \\
{[0.0119]^{* * *}}\end{array}$ & $\begin{array}{l}(0.00517)^{* * *} \\
{[0.00741]^{* * *}}\end{array}$ & $\begin{array}{l}(0.00577)^{* * *} \\
{[0.0112]^{* * *}}\end{array}$ & $\begin{array}{l}(0.00632)^{* * *} \\
{[0.0116]^{* * *}}\end{array}$ \\
\hline $\begin{array}{l}\text { Per capita income } \\
\text { (EUR) }\end{array}$ & & $\begin{array}{l}-0.064 \\
(0.105) \\
{[0.145]}\end{array}$ & $\begin{array}{l}0.207 \\
(0.110)^{*} \\
{[0.139]}\end{array}$ & $\begin{array}{l}-0.206 \\
(0.0766)^{* * *} \\
{[0.0934]^{* *}}\end{array}$ & $\begin{array}{l}0.675 \\
(0.0970)^{* * *} \\
{[0.121]^{* * *}}\end{array}$ & $\begin{array}{l}0.620 \\
(0.0920)^{* * *} \\
{[0.104]^{* * *}}\end{array}$ \\
\hline Degree share (\%) & & $\begin{array}{l}0.889 \\
(0.0779)^{* * *} \\
{[0.131]^{* * *}}\end{array}$ & $\begin{array}{l}0.380 \\
(0.0841)^{* * *} \\
{[0.110]^{* * *}}\end{array}$ & $\begin{array}{l}0.122 \\
(0.0587)^{* *} \\
{[0.0773]}\end{array}$ & $\begin{array}{l}0.550 \\
(0.0813)^{* * *} \\
{[0.129]^{* * *}}\end{array}$ & $\begin{array}{l}0.253 \\
(0.0723)^{* * *} \\
{[0.114]^{* *}}\end{array}$ \\
\hline $\begin{array}{l}\text { Population density } \\
\left(100 \text { residents } / \mathrm{km}^{2} \text { ) }\right.\end{array}$ & & $\begin{array}{l}0.893 \\
(0.0824)^{* * *} \\
{[0.120]^{* * *}}\end{array}$ & $\begin{array}{l}0.325 \\
(0.0809)^{* * *} \\
{[0.104]^{* * *}}\end{array}$ & $\begin{array}{l}0.263 \\
(0.0597)^{* * *} \\
{[0.0741]^{* * *}}\end{array}$ & $\begin{array}{l}0.082 \\
(0.0838) \\
{[0.135]}\end{array}$ & $\begin{array}{l}0.071 \\
(0.0628) \\
{[0.0934]}\end{array}$ \\
\hline Male (\%) & & & $\begin{array}{l}-0.159 \\
(0.330) \\
{[0.318]}\end{array}$ & $\begin{array}{l}0.147 \\
(0.162) \\
{[0.160]}\end{array}$ & $\begin{array}{l}-0.216 \\
(0.193) \\
{[0.188]}\end{array}$ & $\begin{array}{l}-0.260 \\
(0.162) \\
{[0.164]}\end{array}$ \\
\hline $\begin{array}{l}\text { Unemployment rate } \\
\text { (\%) }\end{array}$ & & & $\begin{array}{l}0.634 \\
(0.339)^{*} \\
{[0.383]^{*}}\end{array}$ & $\begin{array}{l}0.315 \\
(0.256) \\
{[0.320]}\end{array}$ & $\begin{array}{l}-1.852 \\
(0.299)^{* * *} \\
{[0.448]^{* * *}}\end{array}$ & $\begin{array}{l}-0.979 \\
(0.301)^{* * *} \\
{[0.385]^{* *}}\end{array}$ \\
\hline $\begin{array}{l}\text { Homeownership rate } \\
\text { (\%) }\end{array}$ & & & $\begin{array}{l}-0.281 \\
(0.0444)^{* * *} \\
{[0.0632]^{* * *}}\end{array}$ & $\begin{array}{l}-0.123 \\
(0.0293)^{* * *} \\
{[0.0389]^{* * *}}\end{array}$ & $\begin{array}{l}0.168 \\
(0.0374)^{* * *} \\
{[0.0550]^{* * *}}\end{array}$ & $\begin{array}{l}0.176 \\
(0.0330)^{* * *} \\
{[0.0435]^{* * *}}\end{array}$ \\
\hline $\begin{array}{l}\text { Car ownership (cars } \\
\text { per capita } \times 100 \text { ) }\end{array}$ & & & $\begin{array}{l}0.082 \\
(0.0747) \\
{[0.0827]}\end{array}$ & $\begin{array}{l}0.102 \\
(0.0555)^{*} \\
{[0.0631]}\end{array}$ & $\begin{array}{l}0.041 \\
(0.0728) \\
{[0.0839]}\end{array}$ & $\begin{array}{l}0.060 \\
(0.0582) \\
{[0.0685]}\end{array}$ \\
\hline $\begin{array}{l}\text { Share tertiary sector } \\
\text { (\%) }\end{array}$ & & & $\begin{array}{l}4.302 \\
(0.995)^{* * *} \\
{[1.884]^{* *}}\end{array}$ & $\begin{array}{l}0.017 \\
(0.779) \\
{[1.214]}\end{array}$ & $\begin{array}{l}-7.075 \\
(0.873)^{* * *} \\
{[1.751]^{* * *}}\end{array}$ & $\begin{array}{l}-1.420 \\
(0.812)^{*} \\
{[1.407]}\end{array}$ \\
\hline $\begin{array}{l}\text { Share secondary sec- } \\
\text { tor (\%) }\end{array}$ & & & $\begin{array}{l}4.042 \\
(0.990)^{* * *} \\
{[1.869]^{* *}}\end{array}$ & $\begin{array}{l}-0.112 \\
(0.774) \\
{[1.206]}\end{array}$ & $\begin{array}{l}-6.986 \\
(0.868)^{* * *} \\
{[1.731]^{* * *}}\end{array}$ & $\begin{array}{l}-1.367 \\
(0.809)^{*} \\
{[1.406]}\end{array}$ \\
\hline Baden (dummy) & & & & $\begin{array}{l}5.212 \\
(0.394)^{* * *} \\
{[0.694]^{* * *}}\end{array}$ & & $\begin{array}{l}-4.622 \\
(0.461)^{* * *} \\
{[0.873]^{* * *}}\end{array}$ \\
\hline $\begin{array}{l}\text { Share conservative } \\
\text { party votes (\%) }\end{array}$ & & & & $\begin{array}{l}-0.618 \\
(0.0389)^{* * *} \\
{[0.0488]^{* * *}}\end{array}$ & & $\begin{array}{l}0.321 \\
(0.0487)^{* * *} \\
{[0.0699]^{* * *}}\end{array}$ \\
\hline $\begin{array}{l}\text { Share green party } \\
\text { votes (\%) }\end{array}$ & & & & $\begin{array}{l}0.657 \\
(0.0824)^{* * *} \\
{[0.106]^{* * *}}\end{array}$ & & $\begin{array}{l}0.955 \\
(0.0910)^{* * *} \\
{[0.124]^{* * *}}\end{array}$ \\
\hline Constant & $\begin{array}{l}30.093 \\
(0.504)^{* * *} \\
{[1.247]^{* * *}}\end{array}$ & $\begin{array}{l}27.666 \\
(0.457)^{* * *} \\
{[0.924]^{* * *}}\end{array}$ & $\begin{array}{l}28.732 \\
(0.522)^{* * *} \\
{[0.968]^{* * *}}\end{array}$ & $\begin{array}{l}28.864 \\
(0.357)^{* * *} \\
{[0.592]^{* * *}}\end{array}$ & $\begin{array}{l}59.700 \\
(0.455)^{* * *} \\
{[1.005]^{* * *}}\end{array}$ & $\begin{array}{l}59.919 \\
(0.421)^{* * *} \\
{[0.837]^{* * *}}\end{array}$ \\
\hline$R^{2}$ & 0.187 & 0.443 & 0.528 & 0.751 & 0.543 & 0.655 \\
\hline $\mathrm{N}$ & 1101 & 1101 & 1101 & 1101 & 1101 & 1101 \\
\hline
\end{tabular}

Notes: OLS estimates. Unit of observation is municipalities. All variables are centered (zero mean) except for the distance measure. All variables refer to 2011, the year of the referendum, except political party shares, which stem from the 2009 federal elections. White-robust standard errors in parentheses, Conley-adjusted standard errors in brackets: ${ }^{*} \mathrm{p}<0.1,{ }^{* *} \mathrm{p}<0.05,{ }^{* * *} \mathrm{p}<0.01$. 
Tab. 3. Determinants of opposition to Stuttgart 21: Alternative Models

\begin{tabular}{|c|c|c|c|c|c|c|}
\hline & (1) & (2) & (3) & (4) & (5) & (6) \\
\hline & $\begin{array}{l}\text { Share yes } \\
\text { votes (\%) }\end{array}$ & $\begin{array}{l}\text { Share yes } \\
\text { votes (\%) }\end{array}$ & $\begin{array}{l}\text { Share yes } \\
\text { votes (\%) }\end{array}$ & $\begin{array}{l}\text { Share yes } \\
\text { votes (\%) }\end{array}$ & $\begin{array}{l}\text { Share yes } \\
\text { votes (\%) }\end{array}$ & $\begin{array}{l}\text { Share yes } \\
\text { votes (\%) }\end{array}$ \\
\hline & WLS & $B C$ & $2 S L S$ & OLS & OLS & OLS \\
\hline Average age (years) & $\begin{array}{l}0.545^{* *} \\
(0.271)\end{array}$ & $\begin{array}{l}0.0381^{* * *} \\
(0.00883)\end{array}$ & $\begin{array}{l}1.065^{* * *} \\
(0.191)\end{array}$ & $\begin{array}{l}1.151^{* * *} \\
(0.204)\end{array}$ & $\begin{array}{l}1.074^{* * *} \\
(0.188)\end{array}$ & \\
\hline Share age $65<(\%)$ & & & & & & $\begin{array}{l}0.233^{* *} \\
(0.0923)\end{array}$ \\
\hline $\begin{array}{l}\text { Distance from Stuttgart } \\
(\mathrm{km})\end{array}$ & $\begin{array}{l}0.0993^{* * *} \\
(0.00819)\end{array}$ & $\begin{array}{l}0.00413^{* * *} \\
(0.000257)\end{array}$ & $\begin{array}{l}0.0537^{* * *} \\
(0.0136)\end{array}$ & & & $\begin{array}{l}0.112^{* * *} \\
(0.00666)\end{array}$ \\
\hline Delta travel time (minutes) & & & & $\begin{array}{l}0.487^{* * *} \\
(0.0982)\end{array}$ & & \\
\hline Turnout (instrumented) & & & $\begin{array}{l}-0.377^{* * *} \\
(0.0851) \\
\end{array}$ & & & \\
\hline Controls & Preferred & Preferred & Preferred & Preferred & Preferred & Preferred \\
\hline S21 distance bins & - & - & - & - & Yes & - \\
\hline $\mathrm{R}^{2}$ & 0.660 & 0.542 & 0.562 & 0.429 & 0.556 & 0.513 \\
\hline $\mathrm{N}$ & 1101 & 1101 & 1101 & 1101 & 1101 & 1101 \\
\hline
\end{tabular}

Notes: Unit of observation is municipalities. Observations in the WLS model are weighted by the electorate. Observations in the BC models are weighted by the inverse square root of the error term's variance (see Footnote 14). Delta travel time is the expected average change in travel time to all other municipalities weighted by the share of out-commuters. The instrument in Model (3) is the 2009 federal election turnout. Stuttgart 21 distance bins are fixed effects for mutually exclusive $10-\mathrm{km}$ distance bins containing municipalities within 0-5 km, 5-15 km, 15-25 km, etc. Preferred controls include the household income, the educational status, population density, unemployment rate, homeownership, the number of registered cars per capita, and the county-level shares of the secondary and tertiary sectors at total employment. Standard errors in parentheses: ${ }^{*} \mathrm{p}<0.1,{ }^{* *} \mathrm{p}<0.05$, ${ }^{* * *}$ $\mathrm{p}<0.01$. 
Tab. 4. Determinants of opposition to Stuttgart 21: 2SLS models

\begin{tabular}{|c|c|c|c|c|c|c|}
\hline & $(1)$ & $(2)$ & (3) & (4) & (5) & (6) \\
\hline & $\begin{array}{l}\text { Share yes } \\
\text { votes (\%) }\end{array}$ & $\begin{array}{l}\text { Share yes } \\
\text { votes (\%) }\end{array}$ & $\begin{array}{l}\text { Share yes } \\
\text { votes (\%) }\end{array}$ & $\begin{array}{l}\text { Share yes } \\
\text { votes (\%) }\end{array}$ & $\begin{array}{l}\text { Share yes } \\
\text { votes (\%) }\end{array}$ & $\begin{array}{l}\text { Share yes } \\
\text { votes (\%) }\end{array}$ \\
\hline Average age & $1.83^{* *}$ & $2.09^{* * *}$ & $6.97^{* * *}$ & $3.79^{*}$ & $2.58^{* * *}$ & $2.63^{* * *}$ \\
\hline (instrumented) & $(0.88)$ & $(0.60)$ & $(2.61)$ & $(2.14)$ & $(0.68)$ & $(0.59)$ \\
\hline Distance from Stuttgart & $0.11^{* * *}$ & $0.11^{* * *}$ & $0.09^{* * *}$ & $0.10^{* * *}$ & $0.10^{* * *}$ & $0.05^{*}$ \\
\hline$(\mathrm{km})$ & (0.019) & (0.019) & $(0.023)$ & $(0.018)$ & $(0.018)$ & $(0.025)$ \\
\hline Turnout (instrumented) & & & & & & $\begin{array}{l}-0.39^{* * *} \\
(0.096) \\
\end{array}$ \\
\hline Covariates set & Preferred & Preferred & Preferred & Preferred & Preferred & Preferred \\
\hline Industry shares & Yes & Yes & Yes & Yes & Yes & Yes \\
\hline Instrumental variables & $\begin{array}{l}\text { Lagged } \\
\text { children }\end{array}$ & $\begin{array}{l}\text { Lagged sec- } \\
\text { tors }\end{array}$ & Geology & $\begin{array}{l}\text { WWII de- } \\
\text { struction }\end{array}$ & All & All \\
\hline Turnout 2009 IV & - & - & - & - & - & Yes \\
\hline CDF F Stat & 34.581 & 37.718 & 7.225 & 7.589 & 16.936 & 16.327 \\
\hline Hansen J P-value & 0.737 & 0.008 & 0.28 & 0.214 & 0.243 & 0.213 \\
\hline $\mathrm{N}$ & 1101 & 1101 & 1101 & 1101 & 1101 & 1101 \\
\hline
\end{tabular}

Notes: Unit of observation is municipalities. Industry shares are the 2011 shares of the secondary and the tertiary sector at employment within a county. Industry shares, and war destruction in rural areas measured at the county level. Controls include income, degree share, population density, share of male voters, unemployment rate, homeownership rate, and the number of registered cars per capita. Lagged children include the share of the population below the age of six, and aged six to fifteen in 1950 and 1961. Lagged sectors include the shares of the secondary and the tertiary sectors in 1961, 1970 and 1987. Geology is a set of dummy variables each of which indicates whether a municipality is within $100 \mathrm{~km}$ of certain mine (e.g. coal). WWII is a set of dummy variables indicating deciles in the distribution of WW2 destruction across municipalities. IV for turnout is the 2009 federal election turnout. Standard errors clustered on counties. ${ }^{*} p<0.10,{ }^{* *} p<0.05,{ }^{* * *} p<0.01$. 
Tab. 5. List of studies

\begin{tabular}{|c|c|c|c|c|c|c|c|}
\hline$\#$ & Year & Author & Publication & $\mathrm{N}$ & Analysis & Topic & Country \\
\hline 1 & 1977 & Rubinfeld & REStat $^{\mathrm{a}}$ & 2 & Survey & School spending & US \\
\hline 2 & 1979 & Fischel & JEEM $^{\mathrm{b}}$ & 1 & Survey & New plant & US \\
\hline 3 & 1982 & Noam & Public choice & 12 & Referendum & Various & Switzerland \\
\hline 4 & 1983 & Ladd \& Wilson & $J_{P A M}{ }^{\mathrm{c}}$ & 1 & Survey & School spending & US \\
\hline 5 & 1983 & Pelinka & Electoral Studies & 1 & Survey & Nuclear energy & Austria \\
\hline 6 & 1988 & Feigenbaum et al. & Public Choice & 1 & Referendum & Nuclear weapons & US \\
\hline 7 & 1992 & Button & $\mathrm{SSQ}^{\mathrm{d}}$ & 6 & Referendum & School spending & US \\
\hline 8 & 1997 & Agostini et al. & Book chapter & 2 & Referendum & Sports facility & US \\
\hline 9 & 2000 & Schulze \& Ursprung & Public Choice & 1 & Referendum & Culture & Switzerland \\
\hline 10 & 2003 & Balsdon et al. & $J_{U E}^{e}$ & 1 & Referendum & School spending & US \\
\hline 11 & 2004 & Brunner \& Balsdon & JUE $^{\mathrm{e}}$ & 1 & Survey & School Spending & US \\
\hline 12 & 2004 & Thalmann & Public Choice & 3 & Survey & Green energy & Sweden \\
\hline 13 & 2005 & Hobolt & JEPOP ${ }^{f}$ & 8 & Survey & EU integration & DK, IE, NO ${ }^{n}$ \\
\hline 14 & 2005 & Rushton & $\mathrm{PBF}^{\mathrm{g}}$ & 1 & Referendum & Culture & US \\
\hline 15 & 2006 & Coates \& Humphreys & JUE & 3 & Referendum & Sports & US \\
\hline 16 & 2006 & Kotchen \& Powers & JEEM $^{\mathrm{b}}$ & 3 & Referendum & Open space & US \\
\hline 17 & 2007 & Dehring et al. & Working paper & 3 & Referendum & Transport & US \\
\hline 18 & 2008 & Bornstein \& Lanz & $\mathrm{EE}^{\mathrm{h}}$ & 3 & Referendum & Green energy & Switzerland \\
\hline 19 & 2008 & Dehring et al. & JUE ${ }^{\mathrm{e}}$ & 1 & Referendum & Sports facility & US \\
\hline 20 & 2009 & Ahlfeldt \& Maennig & Working paper & 3 & Referendum & EU integration & DK, Sweden ${ }^{n}$ \\
\hline 21 & 2010 & Banzhaf et al. & $J_{P A M}{ }^{\mathrm{c}}$ & 1 & Referendum & Land conservation & US \\
\hline 22 & 2010 & Brunner \& Ross & JPubE ${ }^{\mathrm{i}}$ & 1 & Referendum & School spending & US \\
\hline 23 & 2010 & Harsman \& Quigley & $J^{\prime}{ }^{2} M^{C}$ & 1 & Referendum & Road pricing & Sweden \\
\hline 24 & 2010 & Wu \& Cutter & $\mathrm{EE}^{\mathrm{h}}$ & 10 & Referendum & Various & US \\
\hline 25 & 2011 & Ahlfeldt & RSUE $^{\mathrm{j}}$ & 1 & Referendum & Urban development & Germany \\
\hline 26 & 2011 & Ahlfeldt \& Maennig & $\mathrm{UAR}^{\mathrm{k}}$ & 1 & Referendum & Sports facility & Germany \\
\hline 27 & 2012 & Heintzelman et al. & Working paper & 1 & Referendum & Growth boundaries & US \\
\hline 28 & 2013 & Wagschal & Book chapter & 1 & Referendum & Transport & Germany \\
\hline 29 & 2014 & Hersch \& Pelkowski & $A E L^{\prime}$ & 3 & Referendum & Fluoridated water & US \\
\hline 30 & 2015 & Ahlfeldt \& Maennig & $J_{U E}^{e}$ & 1 & Referendum & Transport & Germany \\
\hline 31 & 2015 & Coates \& Wicker & Working paper & 1 & Referendum & Sports & US \\
\hline 32 & 2015 & Horn et al. & CEPm & 3 & Referendum & Sports facility & US \\
\hline 33 & 2015 & Funk \& Gathmann & Economic Policy & 30 & Survey & Various & Switzerland \\
\hline
\end{tabular}

Notes: "N" indicates the number of referendum analyses in a study; "Referendum" indicates the analysis of grouped data by voting precinct; and "Survey" indicates the analysis of individual data from post-referendum surveys, asking the same questions as those in the election. a Review of Economics and Statistics. b Journal of Environmental Economics and Management. ${ }^{c}$ Journal of Policy Analysis and Management. ${ }^{d}$ Social Science Quarterly. ${ }^{e}$ Journal of Urban Economics. ${ }^{\mathrm{f} J o u r n a l}$ of Elections, Public Opinion and Parties. g Public Budgeting and Finance. $\mathrm{h}$ Ecological economics. ${ }^{i}$ Journal of Public Economics ${ }^{j}$ Regional Science and Urban Economics. ${ }^{k}$ Urban Affairs Review. ${ }^{1}$ Applied Economics Letters. ${ }^{m}$ Contemporary Economic Policy. ${ }^{n}$ ISO 2-alpha codes. For further details on the referendums and full references, consider Table A1 in Appendix II. 
Tab. 6. Definition of individualistic lifecycle attitude

\begin{tabular}{|c|c|c|}
\hline Category & $\mathrm{N}$ & Increasing voter age is associated with: \\
\hline Agriculture ${ }^{a}$ & 2 & Lower priority to liberalization (risk aversion and lower dependency on low prices) \\
\hline Culture $^{b}$ & 4 & Lower priority to expenditures on culture \\
\hline Direct democracy ${ }^{\mathrm{a}}$ & 1 & No definition required since attitude is neutral in all referendums \\
\hline Energy & 9 & Lower priority to sustainable energy production \\
\hline Environment & 4 & Lower priority to environmental sustainability (e.g. Pigovian taxes) \\
\hline Foreign aid $^{\mathrm{a}}$ & 1 & No definition required since attitude is neutral in all referendums \\
\hline Health services & 8 & Higher priority to health expenditures and mitigation of (elderly) health risk \\
\hline Infrastructure ${ }^{c}$ & 4 & Lower priority to large public investments in durable capital stock \\
\hline Integration & 14 & $\begin{array}{l}\text { Lower priority to political integration associated with potential long-term eco- } \\
\text { nomic benefits (trade, specialization) and short-term adjustment costs }\end{array}$ \\
\hline Moralities & 4 & No definition required since attitude is neutral in all referendums \\
\hline Law enf. \& defense & 4 & Higher priority to law enforcement and defense (need for security) \\
\hline School spending & 16 & Lower priority to expenditures on education \\
\hline Sports facility ${ }^{b}$ & 10 & Lower priority to large public investments in durable capital stock \\
\hline Transport $^{\mathrm{c}}$ & 16 & Lower priority to large public investments in durable capital stock \\
\hline Urban development & 8 & Lower priority to job creation or housing affordability \\
\hline Welfare & 7 & Lower priority to social programs supporting other groups (e.g. the unemployed) \\
\hline
\end{tabular}

Notes: a Merged into category "Other." b Merged into category "sports and culture“. c Merged into category "Transport and infrastructure". N" indicates the number of referendums in a category. Elderly attitude is neutral if age effect is insignificant. A specific description of the applied decision rule for a number of special cases is included in Appendix II. 
Tab. 7. Lifecycle attitudes: Multivariate analysis

\begin{tabular}{|c|c|c|c|c|c|c|c|}
\hline & (1) & (2) & (3) & (4) & (5) & (6) & (7) \\
\hline Attitude & \multicolumn{6}{|c|}{$\begin{array}{c}1=\text { Individualistic } \\
0=\text { Neutral } \\
-1=\text { Collectivistic }\end{array}$} & $\begin{array}{l}\text { Status } \\
\text { quo vs. } \\
\text { change }\end{array}$ \\
\hline Energy & $\begin{array}{l}1.056^{* * *} \\
(0.099)\end{array}$ & $\begin{array}{l}0.929^{* * *} \\
(0.138)\end{array}$ & $\begin{array}{l}1.014^{* * *} \\
(0.207)\end{array}$ & $\begin{array}{l}1.140^{* * *} \\
(0.148)\end{array}$ & $\begin{array}{l}1.298^{* * *} \\
(0.172)\end{array}$ & $\begin{array}{l}0.592^{* * *} \\
(0.153)\end{array}$ & $\begin{array}{l}0.933^{* * *} \\
(0.183)\end{array}$ \\
\hline Environment & $\begin{array}{l}0.733^{* * *} \\
(0.255)\end{array}$ & $\begin{array}{l}0.496 \\
(0.328)\end{array}$ & $\begin{array}{l}0.651^{*} \\
(0.352)\end{array}$ & $\begin{array}{l}0.734^{* * *} \\
(0.277)\end{array}$ & $\begin{array}{l}0.013 \\
(0.064)\end{array}$ & $\begin{array}{l}0.398^{* * *} \\
(0.145)\end{array}$ & $\begin{array}{l}0.674^{* *} \\
(0.282)\end{array}$ \\
\hline Health services & $\begin{array}{l}0.689^{* * *} \\
(0.219)\end{array}$ & $\begin{array}{l}0.491^{*} \\
(0.278)\end{array}$ & $\begin{array}{l}0.609^{*} \\
(0.322)\end{array}$ & $\begin{array}{l}0.750^{* * *} \\
(0.248)\end{array}$ & $\begin{array}{l}0.799^{* * *} \\
(0.224)\end{array}$ & $\begin{array}{l}0.485^{* * *} \\
(0.184)\end{array}$ & $\begin{array}{l}0.409 \\
(0.267)\end{array}$ \\
\hline Integration & $\begin{array}{l}0.537^{* *} \\
(0.210)\end{array}$ & $\begin{array}{l}0.371 \\
(0.250)\end{array}$ & $\begin{array}{l}0.821^{* * *} \\
(0.309)\end{array}$ & $\begin{array}{l}0.779^{* * *} \\
(0.276)\end{array}$ & $\begin{array}{l}0.904^{* * *} \\
(0.255)\end{array}$ & $\begin{array}{l}0.304^{*} \\
(0.180)\end{array}$ & $\begin{array}{l}0.470^{* *} \\
(0.211)\end{array}$ \\
\hline Morale & $\begin{array}{l}0.073 \\
(0.176)\end{array}$ & $\begin{array}{l}-0.098 \\
(0.220)\end{array}$ & $\begin{array}{l}-0.028 \\
(0.276)\end{array}$ & $\begin{array}{l}0.236 \\
(0.237)\end{array}$ & - & $\begin{array}{l}-0.017 \\
(0.125)\end{array}$ & $\begin{array}{l}0.180 \\
(0.193)\end{array}$ \\
\hline Other & $\begin{array}{l}0.615^{* *} \\
(0.288)\end{array}$ & $\begin{array}{l}0.450 \\
(0.313)\end{array}$ & $\begin{array}{l}0.526 \\
(0.368)\end{array}$ & $\begin{array}{l}0.608^{*} \\
(0.319)\end{array}$ & $\begin{array}{l}0.224 \\
(0.199)\end{array}$ & $\begin{array}{l}0.274 \\
(0.166)\end{array}$ & $\begin{array}{l}0.686^{* *} \\
(0.314)\end{array}$ \\
\hline $\begin{array}{l}\text { Law enforcement \& de- } \\
\text { fense }\end{array}$ & $\begin{array}{l}0.611^{* *} \\
(0.277)\end{array}$ & $\begin{array}{l}0.419 \\
(0.324)\end{array}$ & $\begin{array}{l}0.527 \\
(0.363)\end{array}$ & $\begin{array}{l}0.078 \\
(0.118)\end{array}$ & - & $\begin{array}{l}0.268^{*} \\
(0.159)\end{array}$ & $\begin{array}{l}0.689^{* *} \\
(0.291)\end{array}$ \\
\hline School spending & $\begin{array}{l}0.865^{* * *} \\
(0.146)\end{array}$ & $\begin{array}{l}0.529^{*} \\
(0.312)\end{array}$ & $\begin{array}{l}0.698^{*} \\
(0.386)\end{array}$ & $\begin{array}{l}0.875^{* * *} \\
(0.221)\end{array}$ & $\begin{array}{l}0.951^{* * *} \\
(0.167)\end{array}$ & $\begin{array}{l}0.591^{* * *} \\
(0.139)\end{array}$ & $\begin{array}{l}0.552^{* * *} \\
(0.178)\end{array}$ \\
\hline Sports \& Culture & $\begin{array}{l}0.052 \\
(0.141)\end{array}$ & $\begin{array}{l}-0.160 \\
(0.207)\end{array}$ & $\begin{array}{l}0.028 \\
(0.272)\end{array}$ & $\begin{array}{l}0.021 \\
(0.104)\end{array}$ & - & $\begin{array}{l}0.078 \\
(0.073)\end{array}$ & $\begin{array}{l}-0.053 \\
(0.169)\end{array}$ \\
\hline $\begin{array}{l}\text { Transport \& infrastruc- } \\
\text { ture }\end{array}$ & $\begin{array}{l}0.142 \\
(0.216)\end{array}$ & $\begin{array}{l}-0.053 \\
(0.271)\end{array}$ & $\begin{array}{l}0.132 \\
(0.305)\end{array}$ & $\begin{array}{l}0.373 \\
(0.273)\end{array}$ & $\begin{array}{l}0.589^{*} \\
(0.303)\end{array}$ & $\begin{array}{l}0.108 \\
(0.118)\end{array}$ & $\begin{array}{l}0.067 \\
(0.223)\end{array}$ \\
\hline Urban development & $\begin{array}{l}0.134 \\
(0.291)\end{array}$ & $\begin{array}{l}-0.107 \\
(0.351)\end{array}$ & $\begin{array}{l}0.153 \\
(0.413)\end{array}$ & $\begin{array}{l}0.115 \\
(0.286)\end{array}$ & $\begin{array}{l}0.223 \\
(0.326)\end{array}$ & $\begin{array}{l}0.189 \\
(0.369)\end{array}$ & $\begin{array}{l}-0.110 \\
(0.341)\end{array}$ \\
\hline Welfare & $\begin{array}{l}0.693^{* * *} \\
(0.234)\end{array}$ & $\begin{array}{l}0.528^{* *} \\
(0.264)\end{array}$ & $\begin{array}{l}0.605^{*} \\
(0.324)\end{array}$ & $\begin{array}{l}0.646^{* *} \\
(0.275)\end{array}$ & $\begin{array}{l}1.157^{* * *} \\
(0.381)\end{array}$ & $\begin{array}{l}0.600^{* *} \\
(0.258)\end{array}$ & $\begin{array}{l}0.187 \\
(0.332)\end{array}$ \\
\hline Survey data & $\begin{array}{l}0.017 \\
(0.126)\end{array}$ & $\begin{array}{l}0.062 \\
(0.127)\end{array}$ & $\begin{array}{l}0.068 \\
(0.131)\end{array}$ & $\begin{array}{l}0.060 \\
(0.142)\end{array}$ & $\begin{array}{l}-0.277^{*} \\
(0.155)\end{array}$ & $\begin{array}{l}0.270^{* *} \\
(0.123)\end{array}$ & $\begin{array}{l}-0.508^{* * *} \\
(0.178)\end{array}$ \\
\hline Recommended study & $\begin{array}{l}-0.159 \\
(0.149)\end{array}$ & $\begin{array}{l}-0.023 \\
(0.182)\end{array}$ & $\begin{array}{l}-0.005 \\
(0.166)\end{array}$ & $\begin{array}{l}-0.277 \\
(0.183)\end{array}$ & $\begin{array}{l}-0.247 \\
(0.180)\end{array}$ & $\begin{array}{l}-0.202^{*} \\
(0.103)\end{array}$ & $\begin{array}{l}0.087 \\
(0.184)\end{array}$ \\
\hline Year - 2000 & $\begin{array}{l}0.005 \\
(0.005)\end{array}$ & $\begin{array}{l}0.004 \\
(0.005)\end{array}$ & $\begin{array}{l}0.004 \\
(0.005)\end{array}$ & $\begin{array}{l}-0.001 \\
(0.005)\end{array}$ & $\begin{array}{l}-0.001 \\
(0.006)\end{array}$ & $\begin{array}{l}-0.003 \\
(0.005)\end{array}$ & $\begin{array}{l}0.016^{* *} \\
(0.007)\end{array}$ \\
\hline $\begin{array}{l}\text { US referendum } \\
\text { (base EU) }\end{array}$ & & $\begin{array}{l}0.267 \\
(0.220)\end{array}$ & & & & & \\
\hline $\begin{array}{l}\text { Age increases support } \\
\text { for: } 1=\text { Status-quo, } 0= \\
\text { Neutral, }-1=\text { change }\end{array}$ & & & & & & $\begin{array}{l}0.497^{* * *} \\
(0.107)\end{array}$ & \\
\hline Country effects & - & - & Yes & - & - & - & - \\
\hline Weighted & - & - & - & Yes & - & - & - \\
\hline Sample & All & All & All & All & Unamb. & All & All \\
\hline$N$ & 112.0 & 112 & 112 & 112 & 66 & 112 & 112 \\
\hline $\mathrm{R}^{2}$ & 0.490 & 0.500 & 0.584 & 0.537 & 0.629 & 0.658 & 0.319 \\
\hline
\end{tabular}

Notes: Dependent variable in (1-6) is a variable taking the value of $1 / 0 /-1$ if lifecyle attitudes are encoded as individualistic/neutral/collectivistic. Dependent variable in (7) a variable taking the value of $1 / 0 /-1$ if increases in age are associated with greater support for status quo/no significant effect/change. OLS regression excluding constant to allow for category specific intercepts. Category "other" includes agriculture (2x), direct democracy (1x), and foreign aid $(1 \mathrm{x})$. Weighted estimates are weighted by the inverse of the number of referendums in a study. Unamb. sample excludes referendums where the classification of elderly preferences was potentially controversial (a discussion is in Appendix II, Section 4). White-robust standard errors in parentheses. ${ }^{*} p<0.1,{ }^{* *} p<$ $0.05,{ }^{* * *} p<0.01$. 


\section{Appendix I: \\ Direct democracy and intergenerational conflicts in aging societies}

Version: December 2018

\section{Introduction}

This web appendix complements the Stuttgart 21 case study results reported in the main paper, by providing additional information, robustness checks and auxiliary results. Although it replicates some text from the main paper for better clarity, it is not designed to stand alone or replace the existing content.

\section{Further background}

\subsection{General background}

Plans for a new high-speed rail (HSR) line connecting the German state capitals of Munich (Bavaria) and Stuttgart (Baden-Württemberg) are included in the Trans-European Networks' (TEN-T) Magistrale for Europe HSR project. In the context of this project, it was proposed to redevelop Stuttgart's current terminus central station into an underground through station to increase station capacity and reduce travel times. Originally planned as an extension to the existing station it was later suggested that the construction of a larger underground through station could eventually replace the existing terminus complex, thus freeing up valuable land occupied by track fields for urban development right in the city center (Schubert, 1990).

After the first concept plans were announced in 1994, it took more than 10 years until the final plans for the new station, routing of the feeder lines, and tunnel works were officially approved in early 2005. By April 2006, all legal appeals against the project had been rejected. Three years later, a final agreement on the financing of the Stuttgart 21 project was signed in April 2009. Under the agreed terms the project became a public-private partnership with mixed funding coming from the rail carrier Deutsche Bahn, the German federal state, the state of Baden-Württemberg, the city of Stuttgart, and other stakeholders such as the Stuttgart airport (Stuckenbrock, 2013). 
After the construction works on Stuttgart 21, the official title of the project, started in February 2010, protests against the project steadily increased, even reaching the traditionally non-agitated milieus. The protests achieved wide coverage in German mass media which reported the opposition to be driven by elderly milieus. To give some examples, the Westdeutsche Zeitung reported that older citizens from all political backgrounds took to the streets (Lumme, 2010). Reimann (2010), in Der Spiegel, used the Stuttgart 21 example to connect elderly opposition to reform projects to the phenomenon of population ageing. Kurbjuweit (2010), in his widely-cited essay "Der Wutbürger," meaning enraged citizen, is so upset about the elderly's fierce opposition to Stuttgart 21 and their disregard of the future that he concludes that as Germany ages, it grows weak.

\subsection{Motives of protests against Stuttgart 21}

Excessive costs and inconvenience during the construction period were among the primary concerns brought forth by critics (Kröger, 2010). Other motives and concerns reported in the media included environmental concerns on mineral water resources and the clearing of trees due to the construction works as well as a general discontent with the political decision-making process and heritage issues related to the old central station. The large investment costs along with a discontent about profit appropriation by banks and construction companies and a perceived democratic deficit also came up frequently as concerns reported in surveys. In contrast, geological and environmental concerns, mineral water protection, heritage issues and noise pollution as well as congestion during the construction phase are comparatively more rarely mentioned (Baumgarten \& Rucht, 2013). At the same time, proponents argued that the projected costs were justified in light of the expected travel-time savings, expected creation of jobs, and potential revenues and opportunities for urban development, resulting from the redevelopment of the former track beds (Wagschal, 2013).

In the same way that the Stuttgart 21 project divided the public opinion, it also polarized state politics. In particular, the Green party opposed the construction plans while both the Conservatives and the Social Democrats were generally supporting the project. Compared to Republicans in the US, who tend to oppose state expenditures, Conservatives in Germany are typically more open to public funding of transport projects. This is because they view large parts of transport infrastructure as a natural monopoly and an essential driver of economic growth, which is at the core of their political agenda. As to the Green party's opposition, the main argument was that compared to the alternative of modernizing the existing terminus station, the projected costs were out of proportion, given that the added benefits in terms of fixing a bottleneck and increasing capacity were rather marginal. While the Green party in Germany tends to be more skeptical of infrastructure projects 
than other parties for environmental reasons, direct ecological concerns were not at the center of their campaign against Stuttgart 21. Instead, the main criticism was that resources allocated to the "prestige project" would be better invested in other projects such as the extension and maintenance of existing networks as well as improved links between different transport modes (Bündnis 90 Die Grünen, 2010).

\subsection{Split of investment costs}

Signed in April 2009, the financing agreement between Deutsche Bahn, the German federal state, the state of Baden-Württemberg and the Stuttgart Region as well as the municipality of Stuttgart and Stuttgart airport comprised a budget covering total costs of approximately €4.526 billion, $€ 3.076$ billions of which were estimated for the construction works with an additional $€ 1.450$ billion included as financial buffer. The financing agreement committed the rail carrier Deutsche Bahn to a contribution of $€ 1.563$ billion and the German federal state (including EU co-funding) to cover a share of €1.413 billion. The obligations of the state of Baden-Württemberg were fixed at $€ 0.931$ billion and those of the municipality of Stuttgart at $€ 0.292$ billion. Stuttgart airport agreed to cover $€ 0.227$ billion with the Stuttgart Region (Verband Region Stuttgart) contributing another €0.1 billion.

Based on the agreed numbers, local and regional entities including the state of Baden-Württemberg and the municipality of Stuttgart as well as Stuttgart Airport and the Stuttgart Region were to contribute approximately $34.2 \%$ of the total funding, whereas Deutsche Bahn and the German federal state were to cover shares of $34.5 \%$, respectively $31.2 \%$. For any increases in costs exceeding the financial buffer of $€ 1.450$ billion, a clause on consultations between Deutsche Bahn and the state of Baden Württemberg has been included in the contract. Following several changes in construction cost estimates, the supervisory board of Deutsche Bahn approved a financing framework of $€ 8.200$ billion in January 2018 (Bahnprojekt Stuttgart-Ulm, 2018).

\subsection{Implications for real estate markets}

Being a rich and economically prosperous metropolitan area that houses the headquarters of companies such as Daimler AG (Mercedes-Benz) and Porsche AG, the city of Stuttgart is located in a valley basin surrounded by elevations. The constrained geography in combination with rigid zoning (binding floor area limits), implies that the supply of housing space is inelastic. High demand for residential housing and limited supply lead to high and growing property prices and rents that are sometimes seen as a social issue. By freeing up around 100 hectares of land currently covered by 
track fields for residential housing, commercial estate as well as public parks, the Stuttgart 21 project is expected to have an economic and social impact beyond the anticipated gains from transportation (Buchenau, 2018).

While the development of a new urban district promises the delivery of housing for more than 10,000 residents, this will hardly be enough to sustainably curb rents and prices in a large and growing city like Stuttgart. There is anecdotal evidence reporting that the price growth in Stuttgart is matched by surrounding municipalities like Ludwigsburg (Höhn \& Obergassner, 2018). In this setting, it is unlikely that displaced demand was much of a concern among local voters in the Stuttgart 21 referendum, and we found no evidence in local newspapers, reports, or academic papers that this might have been the case.

\section{Expected travel time changes}

We use two elements to construct our measure of the expected travel time changes that should result from Stuttgart 21 for each municipality. First, we use a matrix of bilateral commuting flows between the municipalities in Baden-Württemberg, which was provided by their Statistical Office. Second, we use a matrix of expected travel time changes between all municipalities, which needs to be approximated as it does not exist. The most detailed information available on how Stuttgart 21 will impact rail travel times in Baden-Württemberg is a matrix of the expected travel time changes between 29 mainline stations reported in a commissioned study by SMA and Partner AG (2010). ${ }^{1}$ To approximate the expected travel time changes between all municipalities, we proceed as follows. First, we assign all municipalities to one of the 29 mainline stations covered in the study, based on their geographic proximity. For their assigned hinterlands, each of these 29 stations typically represents the nearest higher-order rail node through which regional or national trains are directed. Second, for each combination of the 29 stations, we create groups of municipality pairs, which share the same station-to-station route. ${ }^{2}$ Third, assuming that travel times to a station within the hinterlands remain unchanged, we assign the expected travel time change of a given station pair to all pairs of municipalities assigned to it.

1 This matrix incorporates several smaller complementary rail projects, whose realization does not necessarily depend on Stuttgart 21.

2 One of the stations (Bad Cannstatt) remains unconsidered because it is within the boundaries of Stuttgart. Therefore, it has no hinterland according to our definition. 
To compute the expected change of travel time for a given municipality, we use the average of the expected travel time changes to all other municipalities, weighted by their respective shares of outcommuting. To impute commuting shares for several missing relations in the data, we use an estimated commuting decay function of the form:

$$
w_{i j}=\exp \left(-\tau \times d_{i j}\right)
$$

where $w_{i j}$ is a spatial weight in bilateral commuting probabilities, with the share of commuters commuting from municipalities $i$ to $j$ being $w_{i j} / \sum_{j} w_{i j} ; \tau$ is a commuting decay parameter; and $d_{i j}$ is the distance between $i$ and $j$. Our estimate of $\tau=0.064$ is obtained from fitting a negative exponential distance function into the cumulative density function of observable commuting distances. This estimated decay is consistent with recent estimates based on German commuting data (Ahlfeldt et al., 2015). ${ }^{3}$

In Figure A1, we illustrate the expected average travel time change along with the 29 mainline stations and their hinterlands.

3 Ahlfeldt et al. (2015), in their preferred models, estimate decay parameters in the range 0.07-0.077 in terms of travel time. The difference between our estimates and theirs implies an average speed of commuting in our study area of $49.9-54.9 \mathrm{~km} / \mathrm{h}$, which is reasonable for an area with relatively low density and well-developed transport infrastructure. 
Fig. A1. Expected average travel time change
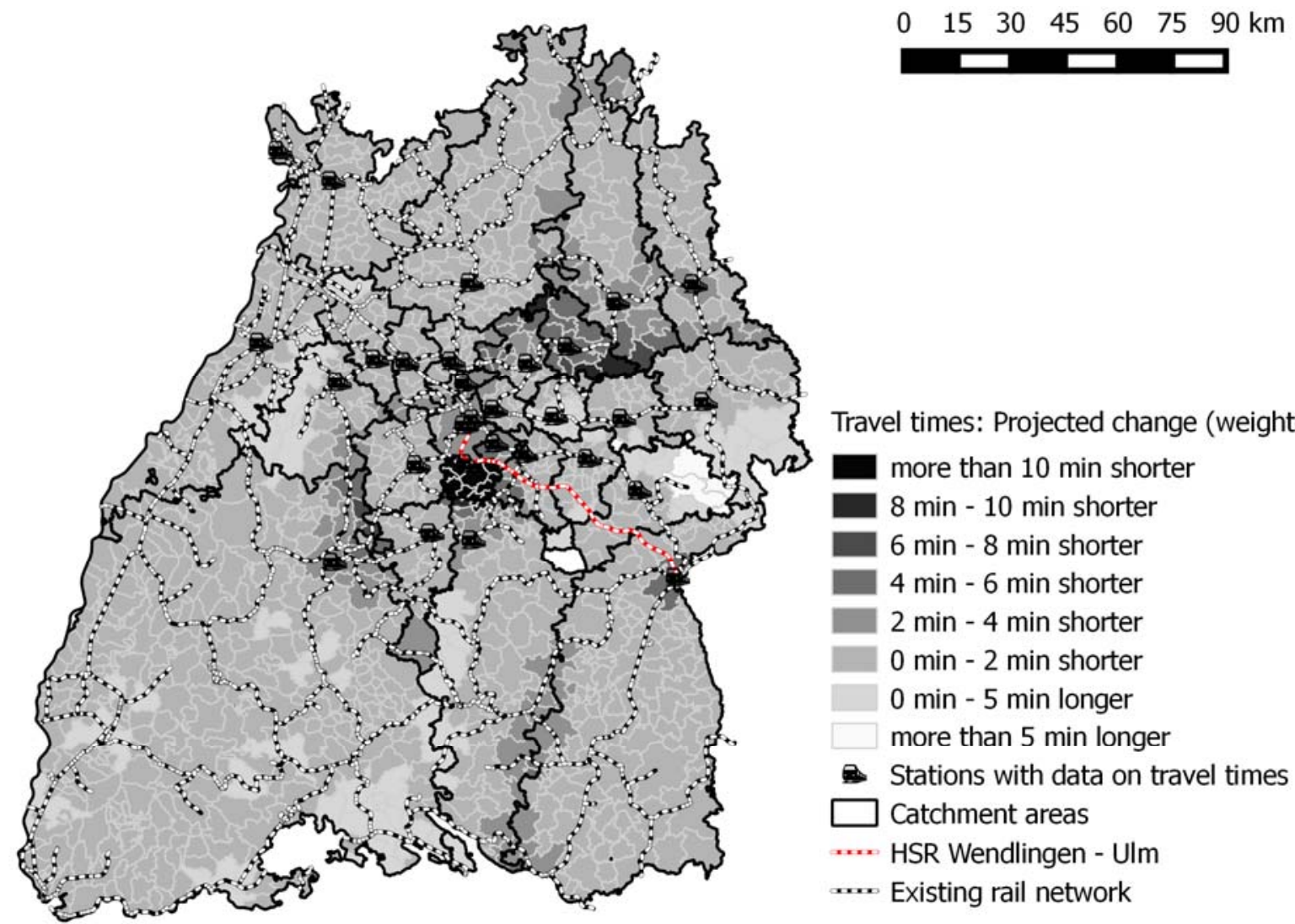

Travel times: Projected change (weighted)

more than 10 min shorter

$8 \mathrm{~min}-10 \mathrm{~min}$ shorter

$6 \mathrm{~min}-8 \mathrm{~min}$ shorter

4 min -6 min shorter

2 min -4 min shorter

0 min - 2 min shorter

0 min - 5 min longer more than 5 min longer

- Stations with data on travel times

Catchment areas

$\ldots$ HSR Wendlingen - Ulm

… Existing rail network

Notes: The expected average travel time change is the average change in the travel time from one municipality to all other municipalities, weighted by their respective shares of out-commuting. Own illustration based on $29 \mathrm{x}$ $29=841$ station pairs' travel time changes computed by SMA and Partner AG (2010). Commuting shares are computed based on the data provided by the Statistical Office of Baden-Württemberg.

\section{Control variables}

Observed confounders are a typical problem in cross-sectional regression analysis. Omitted variables as well as included variables, if endogenous to the variable of interest, can lead to biased estimates. In this section, we present the correlations between our key variables of interest (the voting outcome as well as the average age of the electorate) and a range of potential covariates. We also provide a discussion of how we define the three different sets of control variables that we consider in our analyses.

\subsection{Potential controls}

To control for unobserved factors that potentially have independent effects but are correlated with age, we consider the following control variables. To capture any regional differences in personal involvement, respectively net benefits gained from the Stuttgart 21 project, we include a measure on each municipality's distance from the state capital. On the one hand, an individual voter's benefit 
from the new rail station may be expected to decrease in distance from Stuttgart where the accessibility bottleneck will be removed. On the other, the anticipated obstructions during the construction phase may be larger in areas closer to Stuttgart. We use the linear crow-flight distance to capture the net-effect in our baseline specifications and consider distance bin effects and a commuterweighted measure of expected changes in travel-times as alternative measures.

In line with other studies on the outcome of referendums and other public votes, we consider controls for several socio-economic characteristics. Among others, these include the share of male voters, the per capita income and the local unemployment rate along with measures of the educational status as well as a municipality's population density. The theoretical rationale for these controls is relatively straight forward and, as such, it is no surprise that similar controls are considered in many comparable analyses. We add the homeownership rate as a control to capture potential effects of anticipated asset gains or wealth motives that would be predicted by the homevoter hypothesis (Ahlfeldt and Maennig, 2015; Dehring et al., 2008; Fischel, 2001).

Despite its consequences for urban development, the Stuttgart 21 project is primarily a railway project. As such, it may be valued differently depending on the rail-affinity of an individual voter. For example, frequent users of public transport in general and rail transport in particular may be more supportive of public investments in rail infrastructure than voters who are heavily car dependent. To capture the degree of car dependency, we include the share of registered cars per adult population as a control.

Additional controls considered include measures of the industry composition (as expressed by the share of the secondary and tertiary sector among total county employment in 2011). These controls capture differences in the regional economic structure that may be correlated with local support for large scale infrastructure construction projects. More importantly, these variables are crucial for our IV models in which we use long lags of industry structure (or variables that impact on industry structure). Conditional on contemporary sector shares, it is more likely that historic sector shares impact on contemporary outcomes through a legacy effect on age exclusively.

As a final set of control variables, we consider the shares of the conservative and the green parties in the 2009 federal election as well as a dummy variable denoting whether a municipality is located in the Baden region. The political party variables control for the effects party affiliation may have had on voting in the Stuttgart 21 referendum, given that parties took clear positions as discussed above. We use party shares from the preceding federal election since the 2011 state election was 
likely influenced by the debate on Stuttgart 21 . The Baden-dummy addresses the possibility that residents from the Baden area could have been less supportive of a project that would primarily benefit the Württemberg part (which is where Stuttgart is located). This seems possible given that Baden and Württemberg had historically been independent regions with own cultural and political identities.

The correlations between the abovementioned covariates and the referendum outcome as well as the average age of the electorate are graphically illustrated in Figures A2 and A3. The correlations appear generally stronger with the referendum outcome than with the average age.

Fig. A2. Unconditional correlations between opposition to Stuttgart 21 and covariates
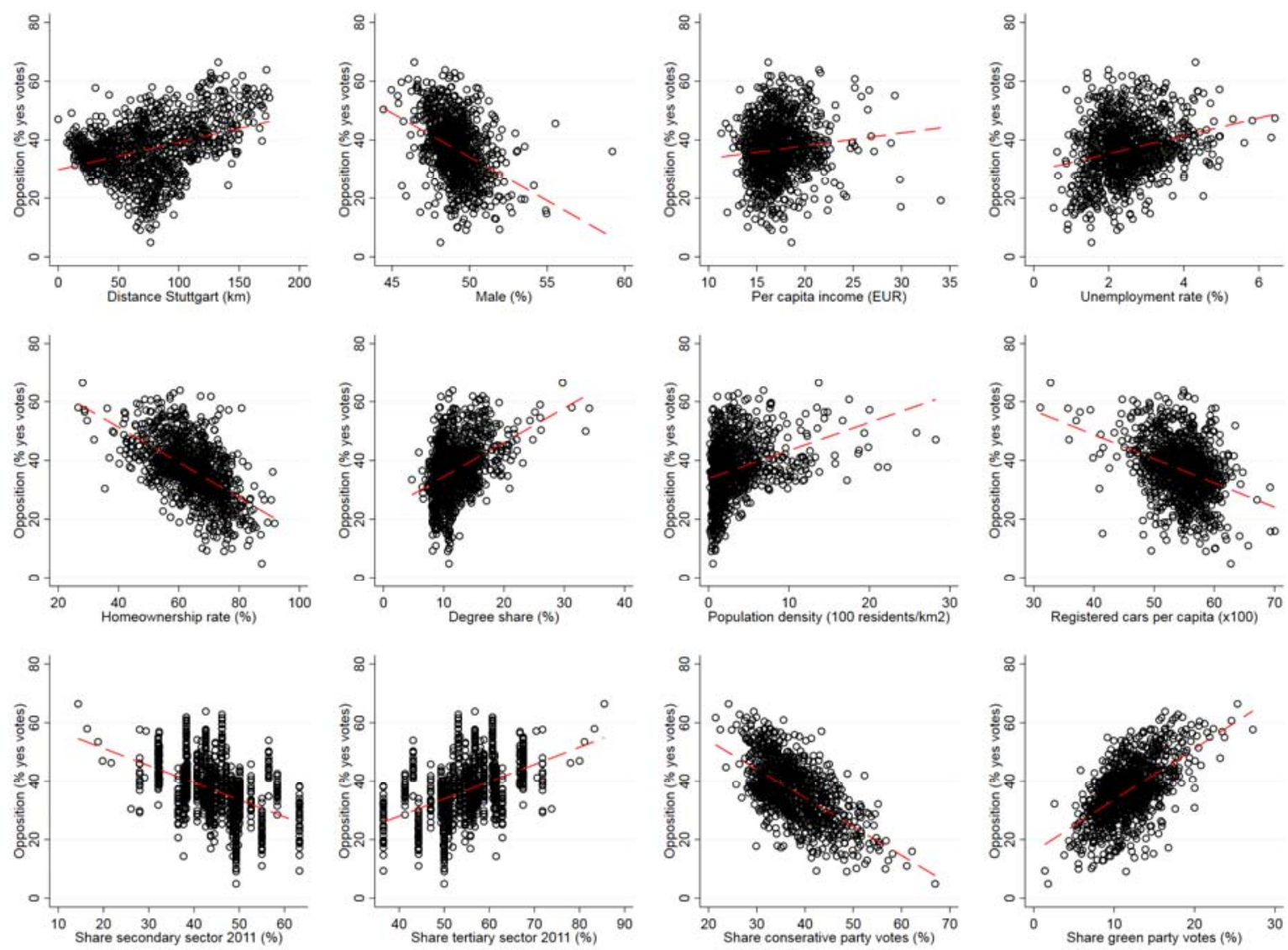

Notes: All panels illustrate raw correlations. One outlier in "male" and on one outlier in "car ownership" dropped to improve the presentation. 
Fig. A3. Unconditional correlations between average age and covariates
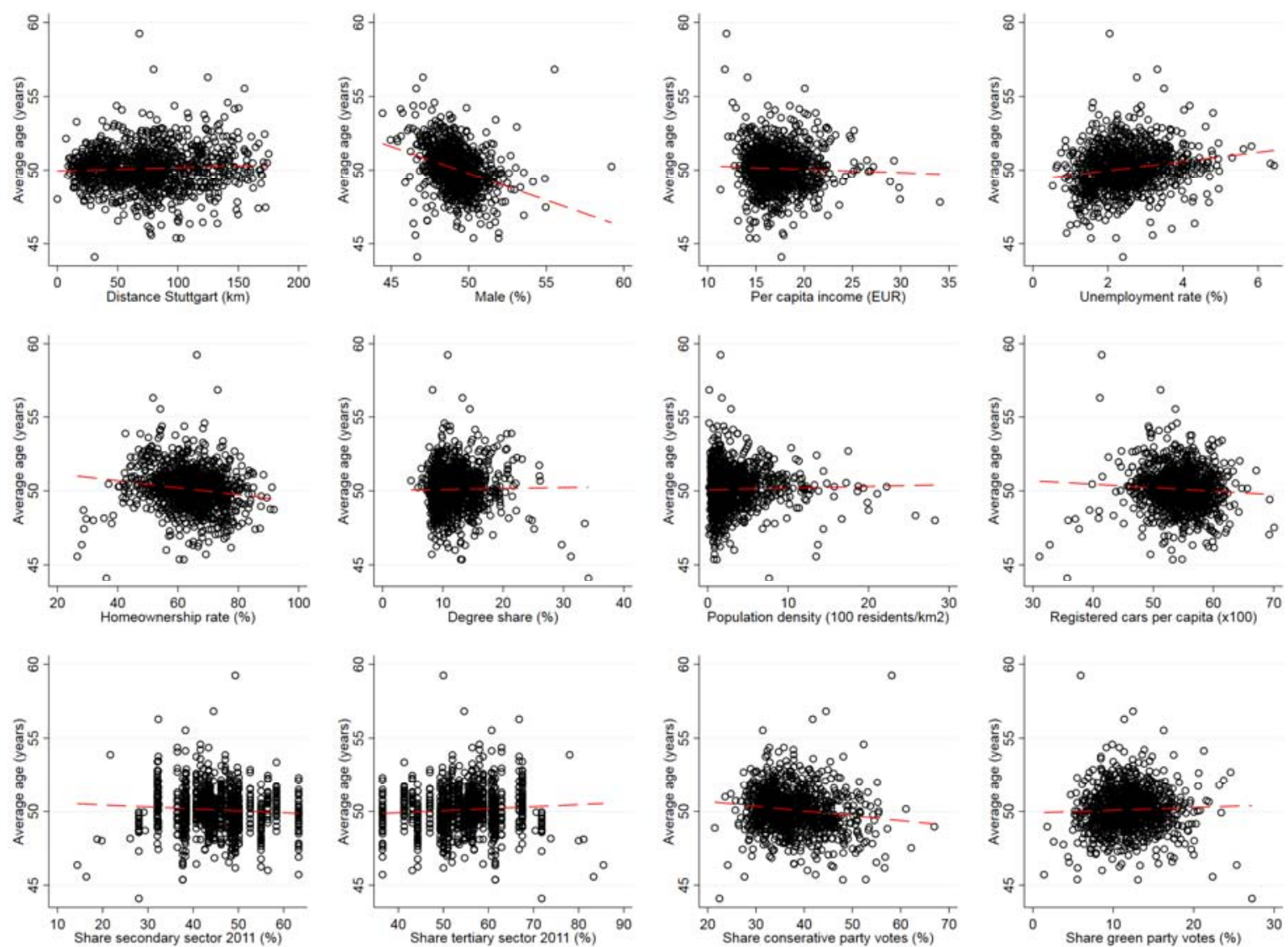

Notes: All panels illustrate raw correlations. One outlier in "male" and on one outlier in "car ownership" dropped to improve the presentation.

\subsection{Choice of covariates}

In selecting our three sets of control variates that we consider at various stages of our empirical analysis, we follow Angrist and Pischke (2009). We start by assuming a fully specified empirical model that links the voting outcome of interest to the average $A G E_{i}$ within a municipality as follows:

$$
\text { PRCNTYYES } S_{i}=\kappa+\varphi A G E_{i}+\gamma S_{i}+\rho a_{i}+\varepsilon_{i}
$$

where $\varphi$ is the marginal effect of interest, $\rho a_{i}$ captures the effect of an unobserved variable $a_{i}$, and all the other variables and parameters are defined as in Equation (1) in the main paper. Next, we assume that there is a variable that is correlated with $a_{i}$ and $A G E_{i}$ and can be expressed as follows:

$$
X_{i}=\pi_{0}+\pi_{1} A G E_{i}+\pi_{2} a_{i}
$$

Solving for $a_{i}=X_{i} \frac{1}{\pi_{2}}-\frac{\pi_{1}}{\pi_{2}} A G E_{i}-\frac{\pi_{0}}{\pi_{2}}$ and substitution into the baseline equation gives 


$$
\operatorname{PRCNTYYES}_{i}=\kappa-\rho \frac{\pi_{0}}{\pi_{2}}+\left(\varphi-\rho \frac{\pi_{1}}{\pi_{2}}\right) A G E_{i}+\gamma S_{i}+\frac{\rho}{\pi_{2}} X_{i}+\varepsilon_{i}
$$

which can be expressed as a reduced-form model that is similar to one we estimate:

$$
\operatorname{PRCNTYES}_{i}=\alpha+\beta A G E_{i}+\gamma S_{i}+\mu X_{i}+\varepsilon_{i}
$$

In our OLS regression models, we infer the structural parameter $\varphi$ from the estimated reducedform coefficient $\hat{\beta}$, so an unbiased estimate implies that $\varphi=\beta$. Let us assume that $\rho>0, \pi_{1}>$ 0 , and $\pi_{2}>0$. Omitting a suitable control for $a_{i}$ will result in $\hat{\beta}>\varphi$, i.e. an upward bias due to an omitted variable problem, if $\operatorname{cov}\left(A G E_{i}, a_{i}\right)>0$. In contrast, if we include a proxy variable $X_{i}$ that is correlated with $a_{i}$ and is itself determined by $A G E_{i}$, we expect downward bias, i.e. an included variable bias or "bad control problem" since $\pi_{1}>0$.

Facing the trade-off between omitted and included variable problems, we seek control variables that are strongly correlated with the unobserved component $\left(\pi_{2}\right.$ is large) but are not themselves determined by age ( $\pi_{1}$ is small). Since $a_{i}$ is unobserved, we cannot estimate $\pi_{2}$ and, thus, rely on intuition to identify suitable candidates. For the same reason, we cannot estimate $\pi_{1}$, i.e. the partial correlation, conditional on the unobserved variable. For an imperfect approximation, we run bivariate regressions of age against various potential control variables and report the standardized coefficients in Table A1.

Of course, those results serve as an imperfect guidance to the selection of potential control variables because the expected bias in the estimated age coefficient does not depend on $\pi_{1}$ alone, but on the ratio $\pi_{1} / \pi_{2}$. Yet, it seems reasonable to conclude that the inclusion of potential "bad controls" likely leads to a downward bias as much as the exclusion of suitable controls leads to an upward bias. Therefore, we interpret estimates of the age effect that are unconditional on potential bad controls as upper-bound estimates and refer to estimates that are conditional on a relatively comprehensive set of bad controls as lower-bound estimates.

Our preferred estimates of the age effect are from a model that excludes the presumably "worst" controls. We consider political controls to be among the potentially worst controls since political party affiliation is a choice variable that is likely determined by age. Not surprisingly, one of the two political party affiliations is a strong predictor of age at the municipality level. Since the political party variables are not independent, we either include or exclude both political variables at a time. We also assign the Baden dummy to the category of worst controls. Not only does this variable have a large standardized regression coefficient, its nature implies that it absorbs a great deal of spatial 
heterogeneity in age, including genuinely exogenous variation. Therefore, we only include these covariates in a set to which we refer as demanding controls. The results reported in Table A1 further reveal strong correlations between age on the one hand and the share of male voters, the unemployment rate, the homeownership rate, the number of registered cars per capita, and the industry composition, on the other. However, the case for these variables to be outcomes that are causally affected by age is not as strong as for political party affiliation. Therefore, we keep these variables in our set of preferred controls. Given the results reported in Table A1, it seems reasonable to conclude that the remaining variables per-capita income, degree share, and population density are unlikely a source of a bad control problem. Hence, these form the set of parsimonious controls.

Tab A1. Marginal effects of covariates on age

\begin{tabular}{|c|c|c|c|c|c|}
\hline Model & Covariate (dependent variable) & $\begin{array}{l}\text { Coefficient } \\
\text { (age effect) }\end{array}$ & $\begin{array}{l}\text { Standard } \\
\text { error }\end{array}$ & $\mathrm{R}^{2}$ & $\mathrm{~N}$ \\
\hline (1) & Distance Stuttgart (km) & $0.061^{* *}$ & 0.03 & 0.0037 & 1101 \\
\hline$(2)$ & Male (\%) & $-0.373^{* * *}$ & 0.028 & 0.139 & 1101 \\
\hline (3) & Per capita income (EUR) & -0.039 & 0.03 & 0.00154 & 1101 \\
\hline (4) & Unemployment rate (\%) & $0.185^{* * *}$ & 0.03 & 0.0341 & 1101 \\
\hline (5) & Homeownership rate (\%) & $-0.157^{* * *}$ & 0.03 & 0.0247 & 1101 \\
\hline (6) & Degree share $(\%)$ & 0.015 & 0.03 & 0.000227 & 1101 \\
\hline (7) & Pop. density (100 residents $/ \mathrm{km}^{2}$ ) & 0.026 & 0.03 & 0.000701 & 1101 \\
\hline (8) & Registered cars per adult population $(x 100)$ & $-0.068^{* * *}$ & 0.030 & 0.0457 & 1101 \\
\hline (9) & Baden $(0,1)$ & $0.206^{* * *}$ & 0.03 & 0.0426 & 1101 \\
\hline (11) & Share conservative party votes (\%) & $-0.140^{* * *}$ & 0.03 & 0.0197 & 1101 \\
\hline (12) & Share green party votes (\%) & 0.042 & 0.03 & 0.00179 & 1101 \\
\hline (13) & Share secondary sector $2011(\%)$ & $-0.072^{* *}$ & 0.03 & 0.00515 & 1101 \\
\hline (14) & Share tertiary sector $2011(\%)$ & $0.074^{* *}$ & 0.03 & 0.00541 & 1101 \\
\hline
\end{tabular}

Notes: Notes: OLS estimates. Unit of observation is municipality. Each coefficient is from a separate regression using the covariate as the dependent variable and age as an independent variable. All variables are standardized to have a standard deviation of one. ${ }^{*} p<0.1,{ }^{* *} p<0.05,{ }^{* * *} p<0.01$.

\subsection{Average age vs. share of yes votes: Conditional correlation control- ling for political party affiliation}

Figure A4 complements Figure 2 in the main paper by showing the correlation between the share of yes votes and the average age controlling for socio-economic characteristics and political variables. Following the argument developed in Section 4.2 in this appendix, the exclusion of relevant controls may induce an omitted variable problem whereas the inclusion of endogenous controls potentially induces an included variable bias problem.

In keeping with intuition and consistent with Table 2 in the main paper, the slope coefficients decrease as we add controls. However, the age effect remains at about two thirds of the size of the preferred model in the specification with the most demanding controls. Interestingly, already the 
parsimonious controls do a good job in bringing the outlying large cities in the upper-left panel of Figure A4 close to the linear fit.

Fig. A4. Conditional correlation between voter opposition and age conditional on varying sets of covariates
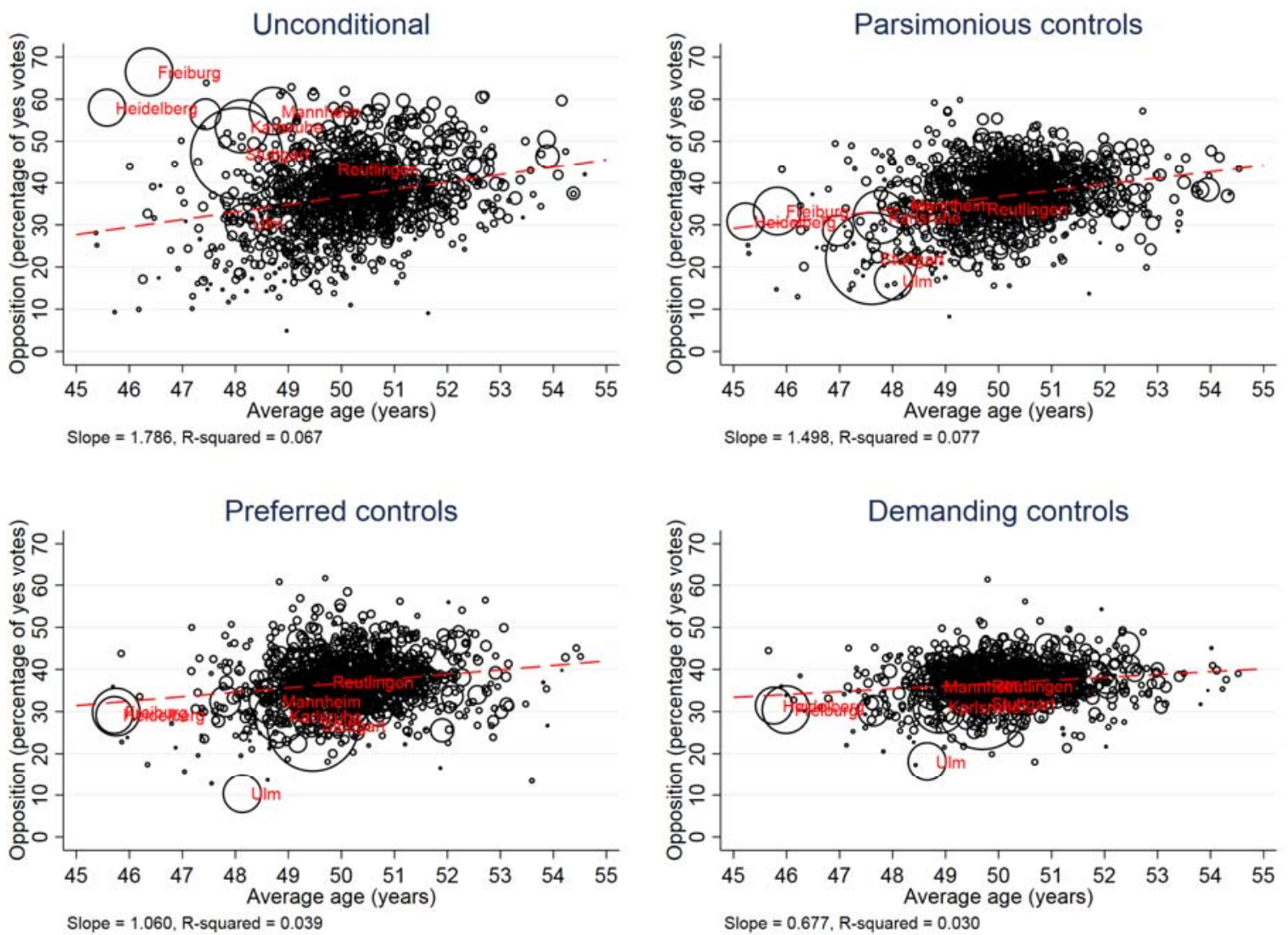

Notes: Average age refers to the adult population (the electorate). Each conditional correlation is based on the residuals of a regression of the share of yes votes against all covariates except age, and that of age against the same covariates. The mean share of yes votes and the mean age are added to the respective residuals. Parsimonious controls include distance from Stuttgart 21, the share of male voters, share of degree holders, and income. Preferred controls, in addition, include unemployment, homeownership, the number of registered cars per capita, and the county-level shares of the secondary and tertiary sectors at total employment. Demanding controls, in addition, include share of Green party votes in the 2009 federal elections, share of Conservative party votes in the same election, and an indicator variable denoting Baden. A small number of outliers are not displayed to improve the presentation. The dashed lines are linear fits into all observations (including outliers). The marker size is proportional to the absolute number of votes. The largest cities are labeled.

\section{Determinants of political party affiliation}

In the main paper, we find that controlling for party affiliation (conservatives and greens) and region (Baden vs. Württemberg) reduces the age effect by about one-third (Table 2, Columns 3 and 4). In Table A2 below, we experiment by either adding party controls (1) or the regional dummy (2). In each case, the age effect is reduced by about 0.2 percentage points or one-sixth compared to 
the model with our preferred set of controls (Table 2, Column 3 in the main paper). When adding both at the same time (Column 3; the same as Table 2, Column 4 in the main paper), the age effect is further reduced by another 0.2 percentage points. In Columns (4-6), we regress the political controls against the other covariates. We find a significant conditional correlation between average age and conservative vote shares, but no significant effect of age on the share of greens votes. The partial correlation between the Baden dummy and the average age is statistically significant.

Tab A2. Political variables

\begin{tabular}{|c|c|c|c|c|c|c|}
\hline & $\begin{array}{l}(1) \\
\text { Share yes } \\
\text { votes (\%) }\end{array}$ & $\begin{array}{l}(2) \\
\text { Share yes } \\
\text { votes (\%) }\end{array}$ & $\begin{array}{l}(3) \\
\text { Share yes } \\
\text { votes (\%) }\end{array}$ & $\begin{array}{l}(4) \\
\text { Conserva- } \\
\text { tives (\%) }\end{array}$ & $\begin{array}{l}\text { (5) } \\
\text { Greens (\%) }\end{array}$ & $\begin{array}{l}\text { (6) } \\
\text { Baden } \\
\text { (dummy) }\end{array}$ \\
\hline Average age (years) & $\begin{array}{l}0.885^{* * *} \\
(0.139)\end{array}$ & $\begin{array}{l}0.857^{* * *} \\
(0.190)\end{array}$ & $\begin{array}{l}0.677^{* * *} \\
(0.133)\end{array}$ & $\begin{array}{l}-0.237^{*} \\
(0.143)\end{array}$ & $\begin{array}{l}0.023 \\
(0.074)\end{array}$ & $\begin{array}{l}0.042^{* * *} \\
(0.009)\end{array}$ \\
\hline $\begin{array}{l}\text { Distance from Stuttgart } \\
(\mathrm{km})\end{array}$ & $\begin{array}{l}0.114^{* * *} \\
(0.005)\end{array}$ & $\begin{array}{l}0.075^{* * *} \\
(0.007)\end{array}$ & $\begin{array}{l}0.075^{* * *} \\
(0.005)\end{array}$ & $\begin{array}{l}0.010^{*} \\
(0.005)\end{array}$ & $\begin{array}{l}0.004 \\
(0.003)\end{array}$ & $\begin{array}{l}0.007^{* * *} \\
(0.000)\end{array}$ \\
\hline Male (\%) & $\begin{array}{l}0.073 \\
(0.181)\end{array}$ & $\begin{array}{l}-0.094 \\
(0.300)\end{array}$ & $\begin{array}{l}0.147 \\
(0.162)\end{array}$ & $\begin{array}{l}0.266 \\
(0.258)\end{array}$ & $\begin{array}{l}-0.108 \\
(0.107)\end{array}$ & $\begin{array}{l}-0.013 \\
(0.013)\end{array}$ \\
\hline Per capita income (EUR) & $\begin{array}{l}-0.134^{*} \\
(0.079)\end{array}$ & $\begin{array}{l}0.162 \\
(0.105)\end{array}$ & $\begin{array}{l}-0.206^{* * *} \\
(0.077)\end{array}$ & $\begin{array}{l}-0.353^{* * *} \\
(0.099)\end{array}$ & $\begin{array}{l}0.222^{* * *} \\
(0.050)\end{array}$ & $\begin{array}{l}0.009 \\
(0.006)\end{array}$ \\
\hline Unemployment rate (\%) & $\begin{array}{l}-0.181 \\
(0.273)\end{array}$ & $\begin{array}{l}0.853^{* * *} \\
(0.327)\end{array}$ & $\begin{array}{l}0.315 \\
(0.256)\end{array}$ & $\begin{array}{l}-1.551^{* * *} \\
(0.262)\end{array}$ & $\begin{array}{l}-0.612^{* * *} \\
(0.128)\end{array}$ & $\begin{array}{l}-0.046^{* *} \\
(0.020)\end{array}$ \\
\hline $\begin{array}{l}\text { Homeownership rate } \\
(\%)\end{array}$ & $\begin{array}{l}-0.176^{* * *} \\
(0.032)\end{array}$ & $\begin{array}{l}-0.243^{* * *} \\
(0.042)\end{array}$ & $\begin{array}{l}-0.123^{* * *} \\
(0.029)\end{array}$ & $\begin{array}{l}0.101^{* * *} \\
(0.036)\end{array}$ & $\begin{array}{l}-0.081^{* * *} \\
(0.016)\end{array}$ & $\begin{array}{l}-0.008^{* * *} \\
(0.002)\end{array}$ \\
\hline Degree share (\%) & $\begin{array}{l}0.051 \\
(0.063)\end{array}$ & $\begin{array}{l}0.487^{* * *} \\
(0.083)\end{array}$ & $\begin{array}{l}0.122^{* *} \\
(0.059)\end{array}$ & $\begin{array}{l}-0.288^{* * *} \\
(0.060)\end{array}$ & $\begin{array}{l}0.300^{* * *} \\
(0.035)\end{array}$ & $\begin{array}{l}-0.022^{* * *} \\
(0.005)\end{array}$ \\
\hline $\begin{array}{l}\text { Population density (100 } \\
\text { residents } / \mathrm{km}^{2} \text { ) }\end{array}$ & $\begin{array}{l}0.228^{* * *} \\
(0.062)\end{array}$ & $\begin{array}{l}0.354^{* * *} \\
(0.079)\end{array}$ & $\begin{array}{l}0.263^{* * *} \\
(0.060)\end{array}$ & $\begin{array}{l}-0.125^{* *} \\
(0.052)\end{array}$ & $\begin{array}{l}0.024 \\
(0.034)\end{array}$ & $\begin{array}{l}-0.006 \\
(0.005)\end{array}$ \\
\hline $\begin{array}{l}\text { Car ownership (cars per } \\
\text { capita x 100)) }\end{array}$ & $\begin{array}{l}0.048 \\
(0.051)\end{array}$ & $\begin{array}{l}0.119 \\
(0.080)\end{array}$ & $\begin{array}{l}0.102^{*} \\
(0.056)\end{array}$ & $\begin{array}{l}-0.070 \\
(0.060)\end{array}$ & $\begin{array}{l}-0.034 \\
(0.027)\end{array}$ & $\begin{array}{l}-0.008^{*} \\
(0.004)\end{array}$ \\
\hline Share tertiary sector (\%) & $\begin{array}{l}3.981^{* * *} \\
(0.775)\end{array}$ & $\begin{array}{l}0.271 \\
(1.007)\end{array}$ & $\begin{array}{l}0.017 \\
(0.779)\end{array}$ & $\begin{array}{l}-1.330^{*} \\
(0.712)\end{array}$ & $\begin{array}{l}-1.402^{* * *} \\
(0.392)\end{array}$ & $\begin{array}{l}0.841^{* * *} \\
(0.055)\end{array}$ \\
\hline $\begin{array}{l}\text { Share secondary sector } \\
(\%)\end{array}$ & $\begin{array}{l}3.788^{* * *} \\
(0.771)\end{array}$ & $\begin{array}{l}0.067 \\
(1.001)\end{array}$ & $\begin{array}{l}-0.112 \\
(0.774)\end{array}$ & $\begin{array}{l}-1.260^{*} \\
(0.711)\end{array}$ & $\begin{array}{l}-1.444^{* * *} \\
(0.389)\end{array}$ & $\begin{array}{l}0.830^{* * *} \\
(0.055)\end{array}$ \\
\hline $\begin{array}{l}\text { Share conservative } \\
\text { party votes }(\%)\end{array}$ & $\begin{array}{l}-0.695^{* * *} \\
(0.040)\end{array}$ & & $\begin{array}{l}-0.618^{* * *} \\
(0.039)\end{array}$ & & & \\
\hline $\begin{array}{l}\text { Share green party votes } \\
(\%)\end{array}$ & $\begin{array}{l}0.430^{* * *} \\
(0.082)\end{array}$ & & $\begin{array}{l}0.657^{* * *} \\
(0.082)\end{array}$ & & & \\
\hline Baden (dummy) & & $\begin{array}{l}4.792^{* * *} \\
(0.502)\end{array}$ & $\begin{array}{l}5.212^{* * *} \\
(0.394)\end{array}$ & & & \\
\hline Constant & $\begin{array}{l}28.366^{* * *} \\
(0.361)\end{array}$ & $\begin{array}{l}29.071^{* * *} \\
(0.521)\end{array}$ & $\begin{array}{l}28.864^{* * *} \\
(0.357)\end{array}$ & $\begin{array}{l}36.684^{* * *} \\
(0.414)\end{array}$ & $\begin{array}{l}11.543^{* * *} \\
(0.208)\end{array}$ & $\begin{array}{l}-0.071^{* *} \\
(0.029)\end{array}$ \\
\hline $\mathrm{R}^{2}$ & 0.710 & 0.565 & 0.751 & 0.326 & 0.415 & 0.389 \\
\hline $\mathrm{N}$ & 1101 & 1101 & 1101 & 1101 & 1101 & 1101 \\
\hline
\end{tabular}

Notes: Average age refers to the adult population (the electorate). All variables are centered (zero mean) except for the distance measure. All variables refer to 2011, the year of the referendum, except political party shares, which stem from the 2009 federal elections. Degree share is approximated at the county level for municipalities with less than 10,000 residents. Robust standard errors are denoted in parentheses. ${ }^{*} \mathrm{p}<0.1,{ }^{* *} \mathrm{p}<0.05$, *** $\mathrm{p}<0.01$. 


\section{Turnout models}

Table A3 complements Tables 2 and 3 in the main paper by providing additional turnout models. We experiment with excluding covariates and using a different proximity to Stuttgart 21 measures. We find that once we expand the set of covariates to our preferred controls, the average age of the electorate has no significant impact on the turnout. The only exception is the model where we combine the travel time-based accessibility measure with potentially endogenous political controls (Column 6). 
Tab A3. Alternative turnout models

\begin{tabular}{|c|c|c|c|c|c|c|}
\hline & $\begin{array}{l}\text { (1) } \\
\text { Turnout } \\
(\%)\end{array}$ & $\begin{array}{l}\text { (2) } \\
\text { Turnout } \\
(\%)\end{array}$ & $\begin{array}{l}\text { (3) } \\
\text { Turnout } \\
(\%)\end{array}$ & $\begin{array}{l}\text { (4) } \\
\text { Turnout } \\
\text { (\%) }\end{array}$ & $\begin{array}{l}\text { (5) } \\
\text { Turnout } \\
(\%)\end{array}$ & $\begin{array}{l}\text { (6) } \\
\text { Turnout } \\
(\%)\end{array}$ \\
\hline Average age (years) & $\begin{array}{l}-0.411^{* *} \\
(0.170)\end{array}$ & $\begin{array}{l}-0.331^{* *} \\
(0.169)\end{array}$ & $\begin{array}{l}-0.097 \\
(0.166)\end{array}$ & $\begin{array}{l}-0.040 \\
(0.189)\end{array}$ & $\begin{array}{l}0.152 \\
(0.134)\end{array}$ & $\begin{array}{l}0.328^{* *} \\
(0.154)\end{array}$ \\
\hline $\begin{array}{l}\text { Distance from } \\
\text { Stuttgart }(\mathrm{km})\end{array}$ & $\begin{array}{l}-0.141^{* * *} \\
(0.00546)\end{array}$ & $\begin{array}{l}-0.139^{* * *} \\
(0.00482)\end{array}$ & & & & \\
\hline $\begin{array}{l}\text { Per capita income } \\
\text { (EUR) }\end{array}$ & & $\begin{array}{l}0.976^{* *} \\
(0.102)\end{array}$ & $\begin{array}{l}0.441^{* * *} \\
(0.0818)\end{array}$ & $\begin{array}{l}0.789^{* * *} \\
(0.130)\end{array}$ & $\begin{array}{l}0.468^{* * *} \\
(0.0794)\end{array}$ & $\begin{array}{l}0.751^{* * *} \\
(0.116)\end{array}$ \\
\hline Degree share (\%) & & $\begin{array}{l}0.371^{* * *} \\
(0.0779)\end{array}$ & $\begin{array}{l}0.433^{* * *} \\
(0.0662)\end{array}$ & $\begin{array}{l}0.728^{* * *} \\
(0.0961)\end{array}$ & $\begin{array}{l}0.213^{* * *} \\
(0.0617)\end{array}$ & $\begin{array}{l}0.355^{* * *} \\
(0.0804)\end{array}$ \\
\hline $\begin{array}{l}\text { Population density } \\
\left(100 \text { residents } / \mathrm{km}^{2}\right)\end{array}$ & & $\begin{array}{l}-0.485^{* * *} \\
(0.0833)\end{array}$ & $\begin{array}{l}-0.178^{* * *} \\
(0.0673)\end{array}$ & $\begin{array}{l}0.498^{* * *} \\
(0.111)\end{array}$ & $\begin{array}{l}-0.119^{* *} \\
(0.0564)\end{array}$ & $\begin{array}{l}0.319^{* * *} \\
(0.0791)\end{array}$ \\
\hline $\begin{array}{l}\text { Unemployment rate } \\
\text { (\%) }\end{array}$ & & & $\begin{array}{l}-1.659^{* * *} \\
(0.278)\end{array}$ & $\begin{array}{l}-0.111 \\
(0.316)\end{array}$ & $\begin{array}{l}-1.003^{* * *} \\
(0.280)\end{array}$ & $\begin{array}{l}-0.372 \\
(0.334)\end{array}$ \\
\hline Male (\%) & & & $\begin{array}{l}-0.348^{*} \\
(0.204)\end{array}$ & $\begin{array}{l}-0.292 \\
(0.239)\end{array}$ & $\begin{array}{l}-0.375^{* *} \\
(0.172)\end{array}$ & $\begin{array}{l}-0.350^{*} \\
(0.193)\end{array}$ \\
\hline $\begin{array}{l}\text { Homeownership rate } \\
\text { (\%) }\end{array}$ & & & $\begin{array}{l}0.223^{* * *} \\
(0.0370)\end{array}$ & $\begin{array}{l}0.402^{* * *} \\
(0.0411)\end{array}$ & $\begin{array}{l}0.191^{* * *} \\
(0.0325)\end{array}$ & $\begin{array}{l}0.288^{* * *} \\
(0.0355)\end{array}$ \\
\hline $\begin{array}{l}\text { Car ownership (cars } \\
\text { per capita x 100) }\end{array}$ & & & $\begin{array}{l}-0.027 \\
(0.0701)\end{array}$ & $\begin{array}{l}0.099 \\
(0.0869)\end{array}$ & $\begin{array}{l}0.008 \\
(0.0584)\end{array}$ & $\begin{array}{l}0.059 \\
(0.0648)\end{array}$ \\
\hline $\begin{array}{l}\text { Share secondary sec- } \\
\text { tor (\%) }\end{array}$ & & & $\begin{array}{l}-5.651^{* * *} \\
(0.844)\end{array}$ & $\begin{array}{l}0.441 \\
(0.932)\end{array}$ & $\begin{array}{l}-0.610 \\
(0.792)\end{array}$ & $\begin{array}{l}5.691^{* * *} \\
(0.771)\end{array}$ \\
\hline Share tertiary sector & & & $\begin{array}{l}-5.767^{* * *} \\
(0.849)\end{array}$ & 0.311 & -0.677 & $5.654^{* * *}$ \\
\hline $\begin{array}{l}(\%) \\
\text { Delta travel time } \\
\text { (minutes) }\end{array}$ & & & $(0.849)$ & $\begin{array}{l}(0.936) \\
-0.994^{* * *} \\
(0.114)\end{array}$ & (0.795) & $\begin{array}{l}(0.771) \\
-0.532^{* * *} \\
(0.0680)\end{array}$ \\
\hline Baden (dummy) & & & & & $\begin{array}{l}-4.388^{* * *} \\
(0.424)\end{array}$ & $\begin{array}{l}-8.013^{* * *} \\
(0.465)\end{array}$ \\
\hline $\begin{array}{l}\text { Share conservative } \\
\text { party votes (\%) } \\
\text { Share green party } \\
\text { votes (\%) }\end{array}$ & & & & & $\begin{array}{l}0.348^{* * *} \\
(0.0501) \\
0.711^{* * *} \\
(0.0866)\end{array}$ & $\begin{array}{l}0.197^{* * *} \\
(0.0521) \\
0.657^{* * *} \\
(0.100)\end{array}$ \\
\hline Constant & $\begin{array}{l}59.341^{* * *} \\
(0.459)\end{array}$ & $\begin{array}{l}59.211^{* * *} \\
(0.415)\end{array}$ & $\begin{array}{l}48.813^{* * *} \\
(0.163)\end{array}$ & $\begin{array}{l}47.899^{* * *} \\
(0.250)\end{array}$ & $\begin{array}{l}50.822^{* * *} \\
(0.210)\end{array}$ & $\begin{array}{l}51.992^{* * *} \\
(0.276)\end{array}$ \\
\hline S21 distance bins & - & - & Yes & 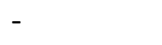 & Yes & - \\
\hline $\mathrm{R}^{2}$ & 0.364 & 0.459 & 0.639 & 0.359 & 0.722 & 0.550 \\
\hline $\mathrm{N}$ & 1101 & 1101 & 1101 & 1101 & 1101 & 1101 \\
\hline
\end{tabular}

Notes: Average age refers to the adult population (the electorate). All variables are centered (zero mean) except for the distance measure. Stuttgart 21 distance bins are the fixed effects for mutually exclusive $10 \mathrm{~km}$ distance bins comprising municipalities within 0-5 km, 5-15 km, 15-25 km, etc. All variables refer to 2011, the year of the referendum, except political party shares, which stem from the 2009 federal elections. Robust standard errors are denoted in parentheses. ${ }^{*} \mathrm{p}<0.1,{ }^{* *} \mathrm{p}<0.05,{ }^{* * *} \mathrm{p}<0.01$.

\section{Robustness and extensions}

\subsection{Alternative models: Complete estimates}

In Table A4, we report the complete results of the models summarized in Table 3 in the main paper, which all include our preferred controls. In Table A5 and Table A6, we replicate the models using the parsimonious and demand controls. The coefficients of the covariates are qualitatively and 
quantitatively consistent with the results reported in Table 2 and Table 3 in the main paper. As with the benchmark models in Table 2 in the main paper, the age effects generally decrease as we add potential bad controls.

Tab A4. Complete results of alternative models, preferred controls

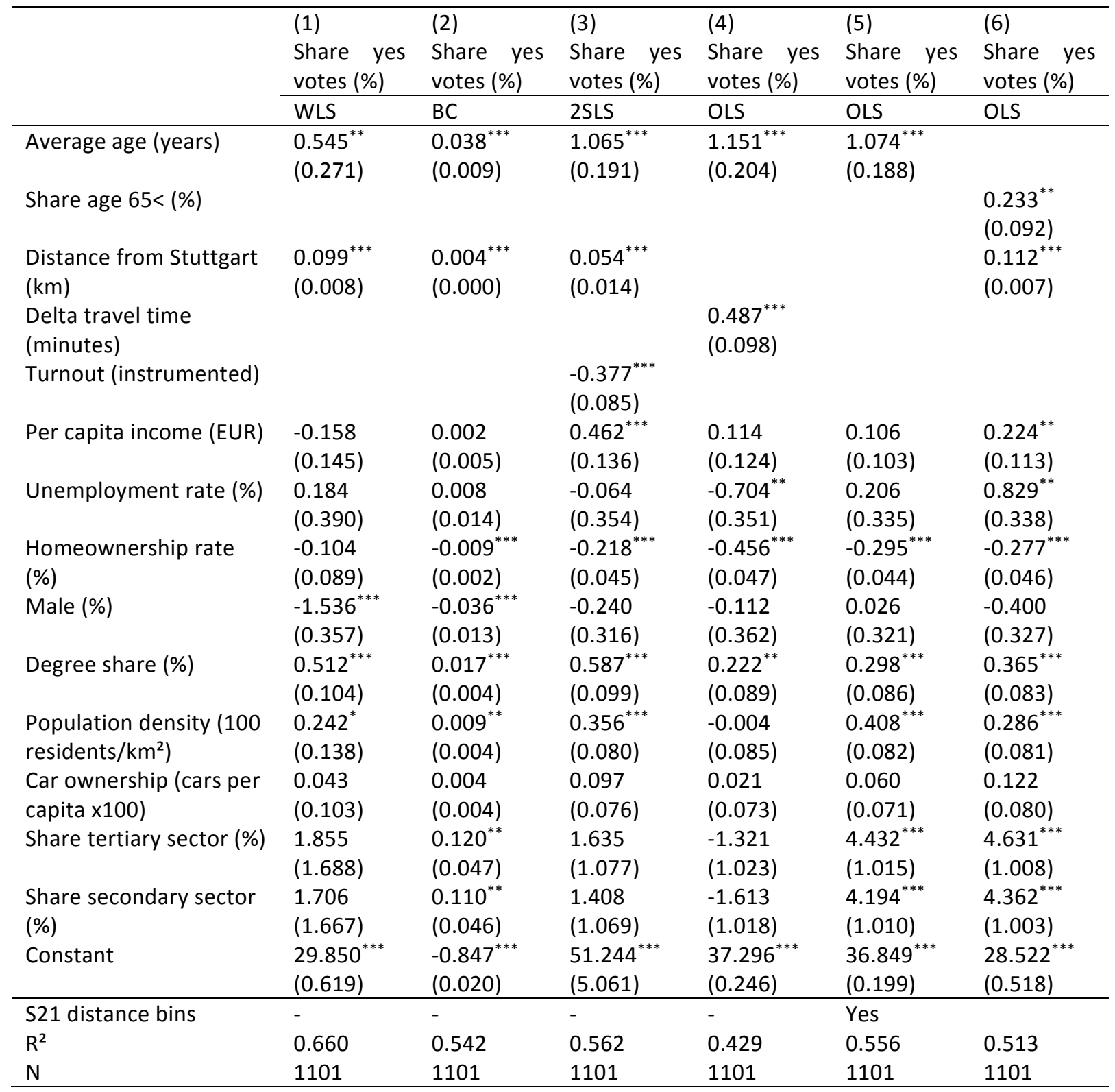

Notes: Average age refers to the adult population (the electorate). All variables are centered (zero mean) except for the distance measure. Stuttgart 21 distance bins are the fixed effects for mutually exclusive $10 \mathrm{~km}$ distance bins comprising municipalities within 0-5 km, 5-15 km, 15-25 km, etc. Delta travel time is the expected average change in travel time to all other municipalities weighted by the share of out-commuters. The instrument in Model (3) is the turnout in the 2009 federal elections. All variables refer to 2011, the year of the referendum, except political party shares, which stem from the 2009 federal elections. * p $<0.1, * * \mathrm{p}<0.05$, *** $\mathrm{p}<$ 0.01 . 
Tab A5. Alternative models, parsimonious controls

\begin{tabular}{|c|c|c|c|c|c|c|}
\hline & (1) & $(2)$ & (3) & (4) & (5) & (6) \\
\hline & Share yes & Share yes & Share yes & Share yes & Share yes & Share yes \\
\hline & votes (\%) & votes (\%) & votes (\%) & votes $(\%)$ & votes (\%) & votes (\%) \\
\hline & WLS & $\mathrm{BC}$ & $2 S L S$ & OLS & OLS & OLS \\
\hline \multirow[t]{2}{*}{ Average age (years) } & $0.994^{* * *}$ & $0.057^{* * *}$ & $1.317^{* * *}$ & $1.572^{* * *}$ & $1.420^{* * *}$ & \\
\hline & $(0.265)$ & $(0.008)$ & (0.199) & $(0.235)$ & $(0.208)$ & \\
\hline \multirow[t]{2}{*}{ Share age $65<(\%)$} & & & & & & $0.509^{* * *}$ \\
\hline & & & & & & $(0.097)$ \\
\hline \multirow{2}{*}{$\begin{array}{l}\text { Distance from Stuttgart } \\
(\mathrm{km})\end{array}$} & $0.117^{* * *}$ & $0.005^{* * *}$ & $0.047^{* * *}$ & & & $0.124^{* * *}$ \\
\hline & $(0.009)$ & $(0.000)$ & $(0.011)$ & & & $(0.006)$ \\
\hline \multirow[t]{2}{*}{ Turnout (instrumented) } & & & $-0.544^{* * *}$ & & & \\
\hline & & & $(0.068)$ & & & \\
\hline \multirow[t]{2}{*}{ Per capita income (EUR) } & $-0.322^{*}$ & -0.006 & $0.467^{* * *}$ & -0.195 & -0.110 & -0.025 \\
\hline & $(0.178)$ & $(0.004)$ & $(0.142)$ & $(0.121)$ & $(0.101)$ & $(0.106)$ \\
\hline \multirow[t]{2}{*}{ Degree share (\%) } & $0.916^{* * *}$ & $0.037^{* * *}$ & $1.091^{* * *}$ & $1.025^{* * *}$ & $0.749^{* * *}$ & $0.882^{* * *}$ \\
\hline & (0.109) & $(0.004)$ & $(0.087)$ & $(0.081)$ & $(0.080)$ & $(0.076)$ \\
\hline \multirow{2}{*}{$\begin{array}{l}\text { Population density (100 } \\
\text { residents } / \mathrm{km}^{2} \text { ) }\end{array}$} & $0.457^{* * *}$ & $0.027^{* * *}$ & $0.629^{* * *}$ & $0.501^{* * *}$ & $0.946^{* * *}$ & $0.846^{* * *}$ \\
\hline & $(0.112)$ & $(0.004)$ & $(0.080)$ & $(0.084)$ & $(0.084)$ & $(0.086)$ \\
\hline \multirow[t]{2}{*}{ Constant } & $29.579^{* * *}$ & $-0.879^{* * *}$ & $59.906^{* * *}$ & $37.440^{* * *}$ & $36.849^{* * *}$ & $27.560^{* * *}$ \\
\hline & $(0.668)$ & $(0.019)$ & $(4.027)$ & $(0.287)$ & $(0.213)$ & $(0.458)$ \\
\hline S21 distance bins & - & - & - & - & Yes & \\
\hline $\mathrm{R}^{2}$ & 0.613 & 0.475 & 0.505 & 0.262 & 0.485 & 0.422 \\
\hline $\mathrm{N}$ & 1101 & 1101 & 1101 & 1101 & 1101 & 1101 \\
\hline
\end{tabular}

Notes: Average age refers to the adult population (the electorate). All variables are centered (zero mean) except for the distance and delta travel time measure. Stuttgart 21 distance bins are the fixed effects for mutually exclusive $10 \mathrm{~km}$ distance bins comprising municipalities within 0-5 km, 5-15 km, 15-25 km, etc. Delta travel time is the expected average change in travel time to all other municipalities weighted by the share of out-commuters. The instrument in Model (3) is the turnout in the 2009 federal elections. All variables refer to 2011, the year of the referendum, except political party shares, which stem from the 2009 federal elections. * p $<$ $0.1, * * \mathrm{p}<0.05, * * * \mathrm{p}<0.01$. 
Tab A6. Alternative models, demanding controls

\begin{tabular}{|c|c|c|c|c|c|c|}
\hline & $\begin{array}{ll}(1) & \\
\text { Share } & \text { yes } \\
\text { votes } & (\%) \\
\text { WLS } & \end{array}$ & $\begin{array}{ll}(2) & \\
\text { Share } & \text { yes } \\
\text { votes } & (\%) \\
\text { BC } & \end{array}$ & $\begin{array}{ll}(3) & \\
\text { Share } & \text { yes } \\
\text { votes } & (\%) \\
2 S L S & \end{array}$ & $\begin{array}{ll}(4) & \\
\text { Share } & \text { yes } \\
\text { votes } & (\%) \\
\text { OLS } & \end{array}$ & $\begin{array}{ll}(5) & \\
\text { Share } & \text { yes } \\
\text { votes } & (\%) \\
\text { OLS } & \end{array}$ & $\begin{array}{ll}(6) & \\
\text { Share yes } \\
\text { votes } \quad(\%) \\
\text { OLS }\end{array}$ \\
\hline Average age (years) & $\begin{array}{l}0.509^{* * *} \\
(0.189)\end{array}$ & $\begin{array}{l}0.030^{* * *} \\
(0.006)\end{array}$ & $\begin{array}{l}0.746^{* * *} \\
(0.134)\end{array}$ & $\begin{array}{l}0.670^{* * *} \\
(0.138)\end{array}$ & $\begin{array}{l}0.697^{* * *} \\
(0.136)\end{array}$ & \\
\hline Share age $65<(\%)$ & & & & & & $\begin{array}{l}0.198^{* * *} \\
(0.063)\end{array}$ \\
\hline $\begin{array}{l}\text { Distance from Stuttgart } \\
(\mathrm{km})\end{array}$ & $\begin{array}{l}0.062^{* * *} \\
(0.010)\end{array}$ & $\begin{array}{l}0.003^{* * *} \\
(0.000)\end{array}$ & $\begin{array}{l}0.044^{* * *} \\
(0.010)\end{array}$ & & & $\begin{array}{l}0.075^{* * *} \\
(0.005)\end{array}$ \\
\hline $\begin{array}{l}\text { Delta travel time } \\
\text { (minutes) }\end{array}$ & & & & $\begin{array}{l}0.079 \\
(0.055)\end{array}$ & & \\
\hline Turnout (instrumented) & & & $\begin{array}{l}-0.260^{* * *} \\
(0.074)\end{array}$ & & & \\
\hline Per capita income (EUR) & $\begin{array}{l}-0.110 \\
(0.148)\end{array}$ & $\begin{array}{l}-0.008^{* *} \\
(0.004)\end{array}$ & $\begin{array}{l}-0.045 \\
(0.086)\end{array}$ & $\begin{array}{l}-0.298^{* * *} \\
(0.083)\end{array}$ & $\begin{array}{l}-0.197^{* *} \\
(0.078)\end{array}$ & $\begin{array}{l}-0.197^{* *} \\
(0.077)\end{array}$ \\
\hline Unemployment rate (\%) & $\begin{array}{l}0.443 \\
(0.405)\end{array}$ & $\begin{array}{l}0.013 \\
(0.011)\end{array}$ & $\begin{array}{l}0.061 \\
(0.249)\end{array}$ & $\begin{array}{l}-0.057 \\
(0.268)\end{array}$ & $\begin{array}{l}0.280 \\
(0.261)\end{array}$ & $\begin{array}{l}0.418 \\
(0.258)\end{array}$ \\
\hline $\begin{array}{l}\text { Homeownership rate } \\
\text { (\%) }\end{array}$ & $\begin{array}{l}-0.027 \\
(0.077)\end{array}$ & $\begin{array}{l}-0.005^{* * *} \\
(0.002)\end{array}$ & $\begin{array}{l}-0.078^{* *} \\
(0.030)\end{array}$ & $\begin{array}{l}-0.187^{* * *} \\
(0.030)\end{array}$ & $\begin{array}{l}-0.119^{* * *} \\
(0.031)\end{array}$ & $\begin{array}{l}-0.115^{* * *} \\
(0.030)\end{array}$ \\
\hline Male (\%) & $\begin{array}{l}-0.418^{* *} \\
(0.194)\end{array}$ & $\begin{array}{l}-0.000 \\
(0.007)\end{array}$ & $\begin{array}{l}0.079 \\
(0.163)\end{array}$ & $\begin{array}{l}0.196 \\
(0.161)\end{array}$ & $\begin{array}{l}0.174 \\
(0.166)\end{array}$ & $\begin{array}{l}0.047 \\
(0.165)\end{array}$ \\
\hline Degree share (\%) & $\begin{array}{l}0.134^{*} \\
(0.081)\end{array}$ & $\begin{array}{l}0.004 \\
(0.002)\end{array}$ & $\begin{array}{l}0.188^{* * *} \\
(0.060)\end{array}$ & $\begin{array}{l}0.043 \\
(0.064)\end{array}$ & $\begin{array}{l}0.130^{* *} \\
(0.060)\end{array}$ & $\begin{array}{l}0.115^{*} \\
(0.059)\end{array}$ \\
\hline $\begin{array}{l}\text { Population density (100 } \\
\text { residents } / \mathrm{km}^{2} \text { ) }\end{array}$ & $\begin{array}{l}0.197^{*} \\
(0.101)\end{array}$ & $\begin{array}{l}0.007^{* * *} \\
(0.003)\end{array}$ & $\begin{array}{l}0.282^{* * *} \\
(0.057)\end{array}$ & $\begin{array}{l}0.100 \\
(0.061)\end{array}$ & $\begin{array}{l}0.295^{* * *} \\
(0.066)\end{array}$ & $\begin{array}{l}0.242^{* * *} \\
(0.060)\end{array}$ \\
\hline $\begin{array}{l}\text { Car ownership (cars per } \\
\text { capita } \times 100 \text { ) }\end{array}$ & $\begin{array}{l}0.051 \\
(0.082)\end{array}$ & $\begin{array}{l}0.005 \\
(0.004)\end{array}$ & $\begin{array}{l}0.118^{* *} \\
(0.055)\end{array}$ & $\begin{array}{l}0.090^{*} \\
(0.054)\end{array}$ & $\begin{array}{l}0.097^{*} \\
(0.057)\end{array}$ & $\begin{array}{l}0.128^{* *} \\
(0.060)\end{array}$ \\
\hline Share tertiary sector (\%) & $\begin{array}{l}-2.261 \\
(1.926)\end{array}$ & $\begin{array}{l}-0.042 \\
(0.045)\end{array}$ & $\begin{array}{l}-0.353 \\
(0.727)\end{array}$ & $\begin{array}{l}-4.642^{* * *} \\
(0.693)\end{array}$ & $\begin{array}{l}-0.112 \\
(0.790)\end{array}$ & $\begin{array}{l}-0.011 \\
(0.791)\end{array}$ \\
\hline $\begin{array}{l}\text { Share secondary sector } \\
\text { (\%) }\end{array}$ & $\begin{array}{l}-2.333 \\
(1.899)\end{array}$ & $\begin{array}{l}-0.046 \\
(0.045)\end{array}$ & $\begin{array}{l}-0.467 \\
(0.722)\end{array}$ & $\begin{array}{l}-4.758^{* * *} \\
(0.689)\end{array}$ & $\begin{array}{l}-0.242 \\
(0.785)\end{array}$ & $\begin{array}{l}-0.142 \\
(0.786)\end{array}$ \\
\hline $\begin{array}{l}\text { Share conservative } \\
\text { party votes (\%) }\end{array}$ & $\begin{array}{l}-0.616^{* * *} \\
(0.059)\end{array}$ & $\begin{array}{l}-0.028^{* * *} \\
(0.002)\end{array}$ & $\begin{array}{l}-0.535^{* * *} \\
(0.046)\end{array}$ & $\begin{array}{l}-0.540^{* * *} \\
(0.040)\end{array}$ & $\begin{array}{l}-0.616^{* * *} \\
(0.041)\end{array}$ & $\begin{array}{l}-0.626^{* * *} \\
(0.039)\end{array}$ \\
\hline $\begin{array}{l}\text { Share green party votes } \\
\text { (\%) }\end{array}$ & $\begin{array}{l}0.651^{* * *} \\
(0.120)\end{array}$ & $\begin{array}{l}0.029^{* * *} \\
(0.003)\end{array}$ & $\begin{array}{l}0.905^{* * *} \\
(0.105)\end{array}$ & $\begin{array}{l}0.846^{* * *} \\
(0.083)\end{array}$ & $\begin{array}{l}0.660^{* * *} \\
(0.088)\end{array}$ & $\begin{array}{l}0.665^{* * *} \\
(0.084)\end{array}$ \\
\hline Baden (dummy) & $\begin{array}{l}6.033^{* * *} \\
(1.129)\end{array}$ & $\begin{array}{l}0.232^{* * *} \\
(0.023)\end{array}$ & $\begin{array}{l}4.010^{* * *} \\
(0.472)\end{array}$ & $\begin{array}{l}7.639^{* * *} \\
(0.369)\end{array}$ & $\begin{array}{l}5.208^{* * *} \\
(0.407)\end{array}$ & $\begin{array}{l}5.410^{* * *} \\
(0.397)\end{array}$ \\
\hline Constant & $\begin{array}{l}29.697^{* * *} \\
(0.511)\end{array}$ & $\begin{array}{l}-0.858^{* * *} \\
(0.015) \\
\end{array}$ & $\begin{array}{l}44.445^{* * *} \\
(4.406)\end{array}$ & $\begin{array}{l}33.424^{* * *} \\
(0.237) \\
\end{array}$ & $\begin{array}{l}34.465^{* * *} \\
(0.239) \\
\end{array}$ & $\begin{array}{l}28.752^{* * *} \\
(0.357)\end{array}$ \\
\hline S21 distance bins & - & - & - & - & Yes & \\
\hline $\mathrm{R}^{2}$ & 0.812 & 0.750 & 0.776 & 0.712 & 0.753 & 0.746 \\
\hline $\mathrm{N}$ & 1101 & 1101 & 1101 & 1101 & 1101 & 1101 \\
\hline
\end{tabular}

Notes: Average age refers to the adult population (the electorate). All variables are centered (zero mean) except for the distance and delta travel time measure. Stuttgart 21 distance bins are the fixed effects for mutually exclusive $10 \mathrm{~km}$ distance bins comprising municipalities within 0-5 km, 5-15 km, 15-25 km, etc. Delta travel time is the expected average change in travel time to all other municipalities weighted by the share of out-commuters. The instrument in Model (3) is the turnout in the 2009 federal elections. All variables refer to 2011, the year of the referendum, except political party shares, which stem from the 2009 federal elections. * p $<$ $0.1, * * \mathrm{p}<0.05, * * * \mathrm{p}<0.01$. 


\subsection{Non-parametric vs. parametric distance to Stuttgart 21 effects}

Our benchmark models control for proximity to Stuttgart 21 using a linear distance measure. In Model (5) of Table 3 in the main paper, we allow for a more flexible functional form by allowing for arbitrary effects within $10 \mathrm{~km}$ distance bins. In Figure A5, we compare the distance effect implied by the parametric benchmark specification (Table 2, Column 3) to the non-parametric bin estimates. It is observed that the parametric functional form is well-aligned with the estimated bin effects. The only notable exception is the first distance bin, which comprises Stuttgart exclusively.

Fig. A5. Determinants of opposition to Stuttgart 21: Parametric vs. non-parametric distance from Stuttgart effect

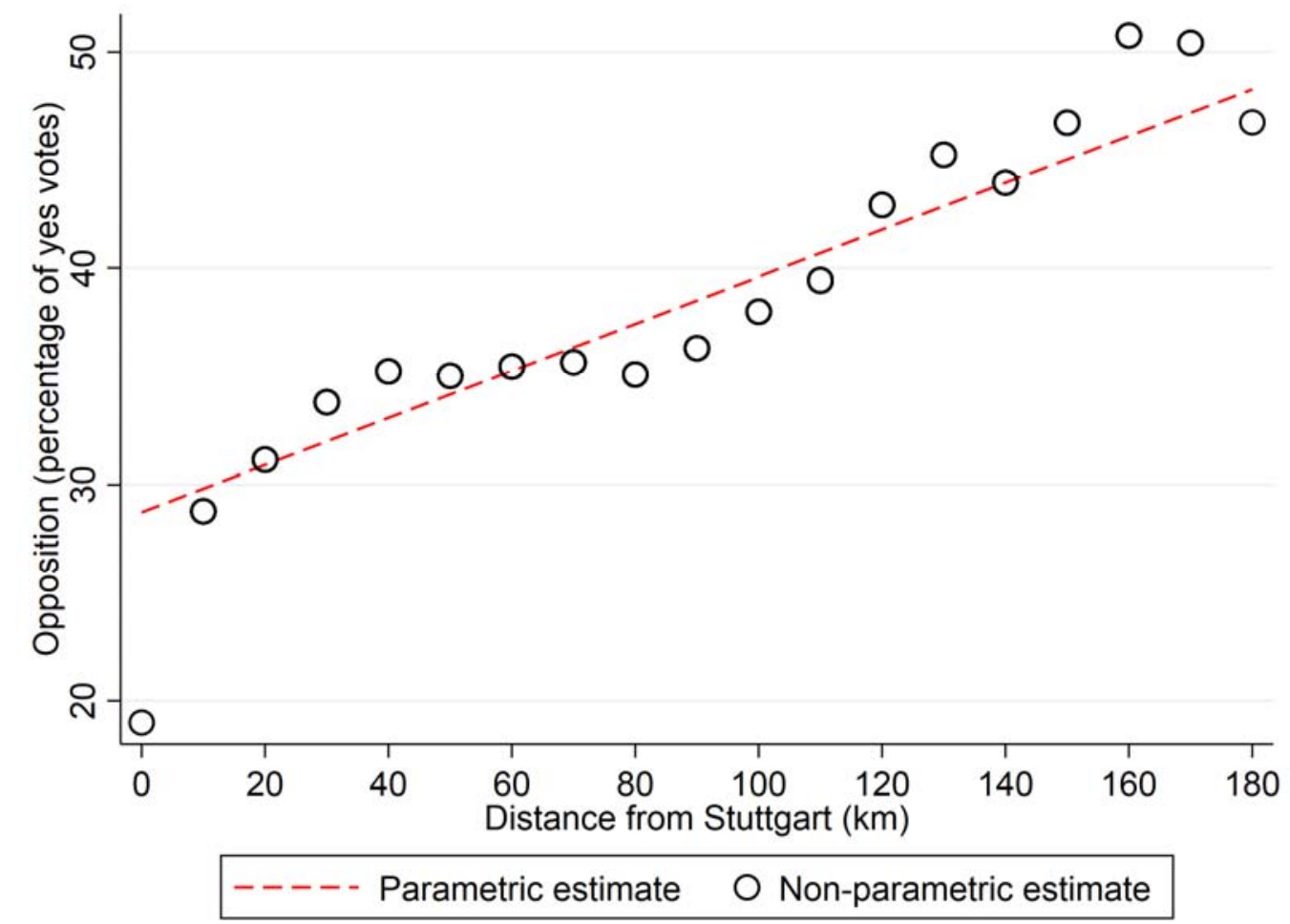

Notes: All estimates are conditional on average age, and the preferred controls as introduced in Section 4.2 of this appendix. Parametric estimates are based on Model (4) in Table 2 in the main paper. Non-parametric estimates are the $10 \mathrm{~km}$ distance from Stuttgart bin effects from Model (5) in Table 3 in the main paper. The first distance bin contains Stuttgart exclusively.

\subsection{Alternative distance cut-off with Conley standard errors}

To allow for arbitrary spatial autocorrelation between neighboring communities, we adjust the standard errors according to Conley (1999). Weights in the covariance matrix estimator linearly decline from 1 to 0 , reaching 0 at the predefined cutoff point. For our baseline models in Table 2 in the main paper, we chose a cutoff of $15.6 \mathrm{~km}$, which corresponds to the average commuting distance in Baden-Württemberg in 2011 (Winkelmann, 2013). In Table A7 we replicate the baseline model 
with preferred controls using varying distance cut-offs in computing Conley errors. Standard errors tend to increase in the distance cutoff at short distance while the trend reverses at large distances $(>100 \mathrm{~km})$. The estimated age effect remains highly statistically significant throughout.

Tab A7. Determinants of opposition to Stuttgart 21: Conley standard errors

\begin{tabular}{lllllll}
\hline & $(1)$ & $(2)$ & $(3)$ & $(4)$ & $(5)$ & $(6)$ \\
& $\begin{array}{l}\text { Share yes } \\
\text { votes (\%) }\end{array}$ & $\begin{array}{l}\text { Share yes } \\
\text { votes (\%) }\end{array}$ & $\begin{array}{l}\text { Share yes } \\
\text { votes (\%) }\end{array}$ & $\begin{array}{l}\text { Share yes } \\
\text { votes (\%) }\end{array}$ & $\begin{array}{l}\text { Share yes } \\
\text { votes (\%) }\end{array}$ & $\begin{array}{l}\text { Share yes } \\
\text { votes (\%) }\end{array}$ \\
\hline Average age (years) & $1.060^{* * *}$ & $1.060^{* * *}$ & $1.060^{* * *}$ & $1.060^{* * *}$ & $1.060^{* * *}$ & $1.060^{* * *}$ \\
& $(0.188)$ & $(0.222)$ & $(0.260)$ & $(0.298)$ & $(0.348)$ & $(0.277)$ \\
Distance from & $0.109^{* * *}$ & $0.109^{* * *}$ & $0.109^{* * *}$ & $0.109^{* * *}$ & $0.109^{* * *}$ & $0.109^{* * *}$ \\
Stuttgart $(\mathrm{km})$ & $(0.008)$ & $(0.012)$ & $(0.016)$ & $(0.020)$ & $(0.023)$ & $(0.020)$ \\
Constant & $28.732^{* * *}$ & $28.732^{* * *}$ & $28.732^{* * *}$ & $28.732^{* * *}$ & $28.732^{* * *}$ & $28.732^{* * *}$ \\
& $(0.599)$ & $(0.947)$ & $(1.398)$ & $(1.763)$ & $(2.140)$ & $(1.675)$ \\
\hline Distance cut-off $(\mathrm{km})$ & 5 & 15 & 30 & 50 & 100 & 250 \\
Controls & Preferred & Preferred & Preferred & Preferred & Preferred & Preferred \\
$\mathrm{R}^{2}$ & 0.528 & 0.528 & 0.528 & 0.528 & 0.528 & 0.528 \\
$\mathrm{~N}$ & 1101 & 1101 & 1101 & 1101 & 1101 & 1101 \\
\hline
\end{tabular}

Notes: Unit of observation is municipalities. Preferred controls include the household income, the educational status, population density, unemployment rate, homeownership, the number of registered cars per capita, and the county-level shares of the secondary and tertiary sectors at total employment. Standard errors computed according to Conley (1999) using the indicated distance cut-offs. Average commuting distance in BadenWuerttemberg is $15.6 \mathrm{~km}$, the cut-off chosen in Table 2 in the main paper. ${ }^{*} p<0.10,{ }^{* *} p<0.05,{ }^{* * *} p<0.01$.

\section{Instrumental variables}

\subsection{Data description}

\subsubsection{Lagged age IVs}

This set of IVs includes the share of population aged 0-6 in 1950 at total municipality population, and likewise the share of population aged 6-15 in 1950, the share of population aged 0-6 in 1961, and the share of population aged 6-15 in 1961. In 2011, the cohort aged 0-15 in 1950 (1961) is aged 61-76 (72-87). These instruments will have some predictive power for the age distribution in 2011, if a significant fraction of the population stays put or returns to their birthplace at some point, e.g. after they retire. We expect a significant cohort effect of the stayers because of the pronounced reduction in the fertility rate from 2.37 to 1.36 births per woman that occurred over the 1960-2011 period in Germany (The World Bank, 2015). Historic population data are from population and employment censuses.

\subsubsection{Lagged sector IVs}

This set of IVs includes the share of employment in the secondary sector at the total county employment in 1961, and likewise the share of employment in the tertiary sector in 1961, as well as the 
shares of the secondary sector and the tertiary sector in the years 1970, and 1987. The intuition is that locations with, at some point in time, a favorable industry composition or transformation likely attracted a young mobile workforce. If a fraction of those movers then stayed put, there will be a legacy on the contemporary age distribution. Historic employment data are from population and employment censuses.

\subsubsection{Geology IVs}

This set of IVs includes six dummy variables, each one takes a value of one if a municipality is within $100 \mathrm{~km}$ of i) a baryite mine, ii) a feldspar mine, iii) a fluorite mine, iv) a petroleum mine, v) a potash mine, vi) a salt rock mine. We argue that access to natural resources was a relevant locational determinant for the manufacturing firms at times when shipping cost were relatively high (Fernihough \& O'Rourke, 2014), but less so today since shipping costs are relatively low (Mohammed \& Williamson, 2004). Thus, access to natural resources serves as a predictor of historic economic performance, which in turn impacts on the contemporary age distribution as discussed in Section 8.1.2. and shown in Section 8.3. in this appendix. Proximity to mines has been computed in a geographic information system using an electronic map provided by the Federal Institute of Geosciences and Natural Resources.

\subsubsection{World War II destruction IVs}

In the World War II destruction IVs, we include set of dummy variables indicating deciles in the distribution of the share of built capital destroyed during World War II across municipalities. The rationale is that the strategic bombing of German cities during World War II had a temporary effect on city growth (and the abovementioned legacy effect on contemporary average age) as shown by Brakman et al (2004). World War II destruction data are from a map displaying the share of destroyed built capital by rural counties and urban municipalities published in a historic atlas (Bardua, 1975).

\subsection{IV estimates with alternative controls}

Tables A8 and A9 replicate Table 4 from the main paper using our sets of parsimonious and demanding controls. The results are qualitatively and quantitatively in line with the pattern emerging from the results reported in the main paper. The IV models yield age effects that are substantially larger than the OLS models. As we add potential bad controls, the estimated age effects decrease. The estimated age effects controlling for the parsimonious controls are generally within the same range or somewhat larger that in Table 4 in the main paper and all highly statistically significant. 
The estimates controlling for the demanding set of controls are qualitatively consistent but tend to be smaller. While in three out of four instrumental variable models, the estimated age effect is not statistically significant, owed to large standard errors, the age effect is highly statistically significant once we use all instrumental variables at a time.

Tab A8. 2SLS models, parsimonious controls

\begin{tabular}{lllllll}
\hline & $(1)$ & $(2)$ & $(3)$ & $(4)$ & $(5)$ & $(6)$ \\
& $\begin{array}{l}\text { Share yes } \\
\text { votes (\%) }\end{array}$ & $\begin{array}{l}\text { Share yes } \\
\text { votes (\%) }\end{array}$ & $\begin{array}{l}\text { Share yes } \\
\text { votes (\%) }\end{array}$ & $\begin{array}{l}\text { Share yes } \\
\text { votes (\%) }\end{array}$ & $\begin{array}{l}\text { Share yes } \\
\text { votes (\%) }\end{array}$ & $\begin{array}{l}\text { Share yes } \\
\text { votes (\%) }\end{array}$ \\
\hline Average age, instru- & $3.16^{* * *}$ & $3.96^{* * *}$ & $6.36^{* * *}$ & $3.62^{* *}$ & $3.44^{* * *}$ & $2.95^{* * *}$ \\
mented (years) & $(0.72)$ & $(0.54)$ & $(2.19)$ & $(1.79)$ & $(0.60)$ & $(0.51)$ \\
Distance from & $0.12^{* * *}$ & $0.11^{* * *}$ & $0.10^{* * *}$ & $0.11^{* * *}$ & $0.12^{* * *}$ & $0.05^{* *}$ \\
Stuttgart (km) & $(0.021)$ & $(0.021)$ & $(0.022)$ & $(0.019)$ & $(0.020)$ & $(0.023)$ \\
Turnout, instru- & & & & & & $-0.44^{* * *}$ \\
mented (\%) & & & & & & $(0.087)$ \\
\hline Covariates set & Parsimo- & Parsimo- & Parsimo- & Parsimo- & Parsimo- & Parsimo- \\
& nious & nious & nious & nious & nious & nious \\
Industry shares & Yes & Yes & Yes & Yes & Yes & Yes \\
\hline Instrumental variables & Lagged & Lagged & Geology & WWII de- & All & All \\
& children & sectors & & struction & & \\
\hline Cragg-Donald F stat. & 52.513 & 48.148 & 10.532 & 9.137 & 19.692 & 20.052 \\
Hansen J statistic & 0.552 & 0.021 & 0.288 & 0.161 & 0.216 & 0.135 \\
$\mathrm{~N}$ & 1101 & 1101 & 1101 & 1101 & 1101 & 1101 \\
\hline
\end{tabular}

Notes: The estimation method is 2SLS in all models. Unit of observation is municipalities. Industry shares, and war destruction in rural areas measured at the county level. Controls include income, degree share, and population density. Lagged children include the share of the population below the age of six, and aged six to fifteen in 1950 and 1961. Lagged sectors include the shares of the secondary and the tertiary sectors in 1961, 1970 and 1987. Geology is a set of dummy variables each of which indicates whether a municipality is within $100 \mathrm{~km}$ of certain mine (e.g. coal). WWII is a set of dummy variables indicating deciles in the distribution of WW2 destruction across municipalities. In Column (6) is turnout in the 2009 federal election used as an additional instrument. Standard errors clustered on counties. ${ }^{*} p<0.10,{ }^{* *} p<0.05,{ }^{* * *} p<0.01$. 
Tab A9. 2SLS models, demanding controls

\begin{tabular}{lllllll}
\hline & $(1)$ & $(2)$ & $(3)$ & $(4)$ & $(5)$ & $(6)$ \\
& $\begin{array}{l}\text { Share yes } \\
\text { votes (\%) }\end{array}$ & $\begin{array}{l}\text { Share yes } \\
\text { votes }(\%)\end{array}$ & $\begin{array}{l}\text { Share yes } \\
\text { votes (\%) }\end{array}$ & $\begin{array}{l}\text { Share yes } \\
\text { votes }(\%)\end{array}$ & $\begin{array}{l}\text { Share yes } \\
\text { votes (\%) }\end{array}$ & $\begin{array}{l}\text { Share yes } \\
\text { votes (\%) }\end{array}$ \\
\hline Average age, & 0.15 & 0.55 & $4.81^{* *}$ & 0.16 & $0.99^{* *}$ & $1.35^{* * *}$ \\
instrumented (years) & $(0.43)$ & $(0.40)$ & $(2.03)$ & $(1.58)$ & $(0.49)$ & $(0.36)$ \\
Distance from Stuttgart & $0.08^{* * *}$ & $0.08^{* * *}$ & $0.07^{* * *}$ & $0.08^{* * *}$ & $0.07^{* * *}$ & $0.03^{* *}$ \\
$(\mathrm{~km})$ & $(0.013)$ & $(0.012)$ & $(0.014)$ & $(0.013)$ & $(0.012)$ & $(0.014)$ \\
Turnout, instrumented & & & & & & $-0.36^{* * *}$ \\
$(\%)$ & & & & & & $(0.091)$ \\
\hline Covariates set & Demanding & Demanding & Demanding & Demanding & Demanding & Demanding \\
Industry shares & Yes & Yes & Yes & Yes & Yes & Yes \\
Instrumental variables & Lagged & Lagged & Geology & WWII & All & All \\
& children & sectors & & destruction & & \\
\hline Cragg-Donald F stat. & 34.002 & 34.234 & 5.622 & 6.123 & 15.913 & 14.446 \\
Hansen J statistic & 0.639 & 0.035 & 0.656 & 0.307 & 0.192 & 0.169 \\
$\mathrm{~N}$ & 1101 & 1101 & 1101 & 1101 & 1101 & 1101 \\
\hline
\end{tabular}

Notes: The estimation method is 2SLS in all models. Unit of observation is municipalities. Industry shares, and war destruction in rural areas measured at the county level. Controls include income, degree share, population density, share of male voters, unemployment rate, homeownership rate, number of registered cars per capita, a dummy for Baden, the share of Conservative party voters, and the share of Green party voters. Lagged children include the share of the population below the age of six, and aged six to fifteen in 1950 and 1961. Lagged sectors include the shares of the secondary and the tertiary sectors in 1961, 1970 and 1987. Geology is a set of dummy variables each of which indicates whether a municipality is within $100 \mathrm{~km}$ of certain mine (e.g. coal). WWII is a set of dummy variables indicating deciles in the distribution of WWII destruction across municipalities. In Column (6) is turnout in the 2009 federal election used as an additional instrument. Standard errors clustered on counties. ${ }^{*} p<0.10,{ }^{* *} p<0.05,{ }^{* * *} p<0.01$.

\subsection{Mechanisms}

The intuition behind three out of our four set of instruments is that a favorable industrial composition or transformation as well as historic factors and events that affect the composition, at some point should have attracted a mobile labor force. As long as a significant fraction of the population stays put, historic industry composition and its determinants should have a legacy effect on the contemporary age structure. While disaggregated historic migration data is difficult to access, we can provide indirect evidence to shed light on the mechanism through which the instruments impact age. First, we show that population growth has reduced average age in our study period since the 1960s, most likely because young mobile workers are attracted to economically prosperous places. Second, we show that growth over the same period was correlated with industry composition in levels and trends.

In Table A10, we regress the yearly change in the log of municipality population on the yearly change in the log of the average age of the adult population separately for selected periods (1-3) and pooled across various periods (4). Consistently, higher population growth is associated with 
reductions in the average age of the adult population, suggesting that the population change is driven by a young mobile workforce. On average, a one-percent increase in population is associated with an 0.8 percent decrease in average age. The effect is somewhat larger during the 1960s and somewhat smaller thereafter.

Tab A10. Effect of population growth on average age

\begin{tabular}{lllll}
\hline & $(1)$ & $(2)$ & $(3)$ & $(4)$ \\
\hline \multicolumn{4}{c}{ Yearly change in log average age } \\
\hline Yearly change in log & $-0.094^{* * *}$ & $-0.055^{* * *}$ & $-0.063^{* * *}$ & $-0.079^{* * *}$ \\
$\quad$ population & $(0.010)$ & $(0.010)$ & $(0.013)$ & $(0.007)$ \\
\hline Base year & 1961 & 1970 & 1987 & $1961-1987$ \\
Period effects & - & - & - & Yes \\
\hline $\mathrm{N}$ & 1101 & 1101 & 1101 & 3303 \\
$\mathrm{R}^{2}$ & 0.105 & 0.0391 & 0.0273 & 0.756 \\
\hline
\end{tabular}

Notes: Unit of observation is municipality in (1)-(3) and municipality-year in (4). Base year 1961 / 1970 / 1987 refers to 1961-1970 / 1970-1987 / 1987-2011 period. Yearly change is the log difference over the period divided by the number of years the period spans. Robust standard error. Average age is computed based on population by age groups (excluding children). ${ }^{*} p<0.1,{ }^{* *} p<0.05,{ }^{* * *} p<0.01$

In Table A11, we regress the yearly change in log population against yearly changes in the shares of the secondary and tertiary sectors at county employment as well as the initial shares. Again, we estimate the effects separately for different periods (1-4) as well as pooled across all periods (5). In general, there is a positive association between larger shares of the secondary and tertiary sectors and population growth. Pooled across all periods, we find positive and highly significant effects of both the initial shares and the changes in shares of the secondary and tertiary sector on the change in log population. By period, the results are more differentiated. During the 1950-1961 period, larger levels and changes in the shares of the secondary and tertiary sector are associated with positive population changes. This is in line with a process of transformation away from a primarysector economy that was still going on. During the 1960-1970 period, the estimates for the initial shares of the secondary and tertiary sector decrease in magnitude but remain positive and highly significant. This is in line with the first signs of a process of industrial transformation towards a more service-orientated economy. During the years from 1970-1987 and the subsequent 19872011 period, we find no significant effect of sectorial composition on population growth. 
Tab A11. Effect of change in industry composition on population growth

\begin{tabular}{llllll}
\hline & $(1)$ & $(2)$ & $(3)$ & $(4)$ & $(5)$ \\
\hline Yearly change in share of & $2.236^{* * *}$ & \multicolumn{4}{c}{ Yearly change in log population } \\
secondary sector & $(0.438)$ & $(0.380)$ & $(1.510)$ & -1.651 & $1.025^{* * *}$ \\
Yearly change in share of & $2.579^{* * *}$ & 0.437 & -0.620 & -1.395 & $(0.197)$ \\
tertiary sector & $(0.685)$ & $(0.453)$ & $(1.826)$ & $(2.112)$ & $(0.380)$ \\
Initial share of secondary & $0.092^{* * *}$ & $0.066^{* * *}$ & -0.032 & -0.083 & $0.067^{* * *}$ \\
sector & $(0.011)$ & $(0.011)$ & $(0.055)$ & $(0.063)$ & $(0.009)$ \\
Initial share of tertiary sec- & $0.114^{* * *}$ & $0.066^{* * *}$ & -0.020 & -0.080 & $0.075^{* * *}$ \\
tor & $(0.016)$ & $(0.019)$ & $(0.063)$ & $(0.064)$ & $(0.011)$ \\
\hline Base year & 1950 & 1961 & 1970 & 1987 & $1950-1987$ \\
Period effects & - & - & - & - & Yes \\
\hline $\mathrm{N}$ & 1101 & 1101 & 1101 & 1101 & 4404 \\
$\mathrm{R}^{2}$ & 0.201 & 0.103 & 0.0355 & 0.0246 & 0.242 \\
\hline
\end{tabular}

Notes: Unit of observation is municipality in (1)-(4) and municipality-year in (5). Base year 1950 / 1961 / 1970 / 1987 refers to $1950-1961$ / 1961-1970 / 1970-1987 / 1987-2011 period. Yearly change is the log difference over the period divided by the number of years the period spans. Sector shares measured at county level. Standard errors clustered on counties. ${ }^{*} p<0.1,{ }^{* *} p<0.05,{ }^{* * *} p<0.01$.

Overall, the evidence suggests that industry mix has had a significant impact on economic growth in Baden-Württemberg during the third quarter of the $20^{\text {th }}$ century, which is in line with evidence from the US (Glaeser et al., 1992; Henderson et al., 1995). Given the evidence from Table A10, this impact should have translated into an effect on average age, likely through migration of young mobile professionals.

\subsection{Validity of instruments}

While there are standardized statistical tests for the relevance of instruments, evaluating the validity of instruments is generally more difficult. The rationale for our geology and WWII instruments rests on two assumptions. First, the instruments serve to predict the economic performance of regions in the past, which in turn should have affected the attraction of a young workforce. Second, the instruments no longer have a direct effect on the outcome of interest today (opposition to Stuttgart 21). Thus, the effect on the outcome is a legacy effect that operates through the impact on the age distribution due to limited mobility of mature individuals. To justify the exclusion restriction, we argue that access to natural resources was a relevant locational determinant for the manufacturing firms at times when shipping cost were relatively high (Fernihough \& O'Rourke, 2014), but less so today since shipping costs are relatively low (Mohammed \& Williamson, 2004). For the excludability of World War II destruction, we refer to Brakman et al (2004), who show that WWII bombing had a sizable but temporary effect on the economic geography of Germany. 
Table A12 provides an indirect test of these assumptions by testing the predictive power that our instrumental variables have in explaining the industry composition and population growth at different points in time. To this end, we report the $\mathrm{R}^{2}$ of separate regressions for each set of instrumental variables on the share of the secondary sector at total employment, the share of the tertiary sector at total employment, and the population growth at different points in time. In line with the assumptions made, we find that the predictive power of the instruments has decreased significantly over time. It seems reasonable to argue that, conditional on contemporary industry composition, those instruments capture factors that were relevant in the past but are not today.

Tab A12. Predictive power of instrumental variables for outcomes over time

\begin{tabular}{lcccccc}
\hline Covariates & Geology & WWII & Geology & WWII & Geology & WWII \\
$\begin{array}{l}\text { Dependent } \\
\text { variable }\end{array}$ & $\begin{array}{r}\text { Share secondary sector at } \\
\text { total employment }\end{array}$ & $\begin{array}{r}\text { Share tertiary sector at to- } \\
\text { tal employment }\end{array}$ & $\begin{array}{c}\text { Log-change in population } \\
\text { over subsequent period }\end{array}$ \\
\hline 1950 & 0.302 & 0.154 & 0.566 & 0.231 & 0.162 & 0.101 \\
1961 & 0.198 & 0.047 & 0.237 & 0.076 & 0.100 & 0.109 \\
1970 & 0.215 & 0.051 & 0.226 & 0.102 & 0.052 & 0.054 \\
1987 & 0.138 & 0.053 & 0.140 & 0.112 & 0.032 & 0.047 \\
2011 & 0.051 & 0.048 & 0.127 & 0.129 & - & - \\
\hline
\end{tabular}

Notes: Each cell gives the $\mathrm{R}^{2}$ from a regression of a dependent variable measured in a given year against a set of covariates. Geology is a set of dummy variables each of which indicates whether a municipality is within 100 $\mathrm{km}$ of certain mine (e.g. coal). WWII is a set of dummy variables indicating deciles in the distribution of WWII destruction across municipalities.

\section{Interaction models}

Table A13 presents the estimates of the interaction effects between our measure of average age and the covariates discussed in Section 2.5 of the main paper. The main purpose of our analysis of heterogeneity in the age effect is to evaluate whether the discrepancy between the OLS and the IV estimates is likely to reflect that the IV models yield local average treatment effects that are not representative for the population of municipalities. For this purpose, we add to the baseline models a set of interaction terms between the age variable of primary interest and one of the three different sets of covariates introduced in Section 4 of this appendix. We add contemporary industry shares to the IV models to more plausibly meet the exclusion restrictions. For consistency, we also add contemporary industry shares to the OLS models in Table A13. Because we rescale all covariates to have a zero mean, the coefficient of the non-interacted age variable in Table A13 displays the marginal effect of age for a municipality with mean characteristics. 
The main takeaway from the analysis is that once we compute the marginal effect of age for municipalities with comparable characteristics, the difference in the age effect from the OLS and IV estimates diminishes. In the non-interacted models with preferred controls, the IV age effect exceeds the OLS age effect by as much as (2.58/1.06-1=) 143\% (using all IVs). This markup decreases to (1.89/1.22-1) 54\% when we consider the marginal age effect for the municipality with mean characteristics (Table A13, Columns 5 vs. 2). Allowing for heterogeneity in the age effect along dimensions covered by the set of demanding controls, the markup further shrinks to $(0.86 / 0.69-1=) 25 \%$ (Columns 6 vs. 3). Figure A6 further illustrates how the peaks of the distributions of the marginal effects (preferred controls) are closer to each other than the point estimates from the non-interacted OLS and IV models. These results suggest that the difference between the non-interaction OLS and IV estimates reported in the main paper is likely to be at least partially due to the IV estimates being a local estimate of a municipality in the upper tail of the distribution of marginal age effects.

Tab A13. Determinants of opposition to Stuttgart 21: Interaction models

\begin{tabular}{lllllll}
\hline & $(1)$ & $(2)$ & $(3)$ & $(4)$ & $(5)$ & $(6)$ \\
& Share yes & Share yes & Share yes & Share yes & Share yes & Share yes \\
& votes (\%) & votes (\%) & votes (\%) & votes (\%) & votes (\%) & votes (\%) \\
& OLS & OLS & OLS & 2SLS & 2SLS & 2SLS \\
\hline Average age (years) & $1.553^{* * *}$ & $1.223^{* * *}$ & $0.688^{* * *}$ & $2.639^{* * *}$ & $1.889^{* * *}$ & $0.864^{* * *}$ \\
& $(0.278)$ & $(0.291)$ & $(0.201)$ & $(0.462)$ & $(0.484)$ & $(0.317)$ \\
Distance from & $0.123^{* * *}$ & $0.109^{* * *}$ & $0.076^{* * *}$ & $0.120^{* * *}$ & $0.107^{* * *}$ & $0.076^{* * *}$ \\
Stuttgart (km) & $(0.019)$ & $(0.018)$ & $(0.012)$ & $(0.020)$ & $(0.017)$ & $(0.011)$ \\
Per capita income & 0.184 & $0.255^{*}$ & -0.196 & $0.274^{*}$ & $0.280^{* *}$ & -0.192 \\
(EUR) & $(0.133)$ & $(0.144)$ & $(0.118)$ & $(0.142)$ & $(0.137)$ & $(0.125)$ \\
Degree share (\%) & $0.456^{* * *}$ & $0.317^{*}$ & 0.111 & $0.376^{* *}$ & $0.283^{*}$ & 0.110 \\
& $(0.165)$ & $(0.162)$ & $(0.120)$ & $(0.175)$ & $(0.161)$ & $(0.117)$ \\
Population density & $0.744^{* * *}$ & $0.220^{* *}$ & $0.220^{* * *}$ & $0.700^{* * *}$ & $0.175^{*}$ & $0.202^{* *}$ \\
(100 residents/km $\left.{ }^{2}\right)$ & $(0.124)$ & $(0.092)$ & $(0.076)$ & $(0.116)$ & $(0.097)$ & $(0.078)$ \\
Male (\%) & & -0.466 & 0.067 & & -0.236 & 0.091 \\
& & $(0.291)$ & $(0.154)$ & & $(0.342)$ & $(0.173)$ \\
Unemployment rate & & 0.618 & 0.356 & & 0.538 & 0.426 \\
(\%) & & $(0.485)$ & $(0.378)$ & & $(0.498)$ & $(0.388)$ \\
Homeownership rate & & $-0.275^{* * *}$ & $-0.134^{* * *}$ & & $-0.279^{* * *}$ & $-0.136^{* * *}$ \\
(\%) & & $(0.083)$ & $(0.049)$ & & $(0.077)$ & $(0.047)$ \\
Car ownership (cars & & 0.020 & 0.081 & & -0.041 & 0.063 \\
per capita x100) & & $(0.096)$ & $(0.083)$ & & $(0.085)$ & $(0.082)$ \\
Share tertiary sector & 3.647 & 3.895 & 0.105 & 2.808 & 3.502 & 0.084 \\
(\%) & $(3.580)$ & $(3.165)$ & $(2.151)$ & $(3.289)$ & $(2.824)$ & $(2.069)$ \\
Share secondary & 3.329 & 3.637 & -0.030 & 2.503 & 3.241 & -0.054 \\
sector (\%) & $(3.528)$ & $(3.124)$ & $(2.121)$ & $(3.236)$ & $(2.784)$ & $(2.038)$ \\
Baden (dummy) & & & $5.111^{* * *}$ & & & $5.009^{* * *}$ \\
& & & $(1.193)$ & & & $(1.169)$ \\
Share conservative & & & $-0.588^{* * *}$ & & & $-0.563^{* * *}$ \\
party votes (\%) & & & $(0.065)$ & & & $(0.063)$ \\
& & & & & &
\end{tabular}




\begin{tabular}{|c|c|c|c|c|c|c|}
\hline & (1) & (2) & (3) & (4) & (5) & (6) \\
\hline & $\begin{array}{l}\text { Share yes } \\
\text { votes (\%) }\end{array}$ & $\begin{array}{l}\text { Share yes } \\
\text { votes (\%) }\end{array}$ & $\begin{array}{l}\text { Share yes } \\
\text { votes (\%) }\end{array}$ & $\begin{array}{l}\text { Share yes } \\
\text { votes (\%) }\end{array}$ & $\begin{array}{l}\text { Share yes } \\
\text { votes (\%) }\end{array}$ & $\begin{array}{l}\text { Share yes } \\
\text { votes (\%) }\end{array}$ \\
\hline & OLS & OLS & OLS & $2 S L S$ & $2 S L S$ & $2 S L S$ \\
\hline $\begin{array}{l}\text { Share green party } \\
\text { votes (\%) }\end{array}$ & & & $\begin{array}{l}0.644^{* * *} \\
(0.165)\end{array}$ & & & $\begin{array}{l}0.647^{* * *} \\
(0.162)\end{array}$ \\
\hline Age $\times$ Distance from & -0.006 & -0.004 & -0.000 & -0.013 & -0.002 & 0.002 \\
\hline Stuttgart (km) & $(0.007)$ & $(0.007)$ & $(0.005)$ & $(0.015)$ & $(0.011)$ & $(0.008)$ \\
\hline $\begin{array}{l}\text { Age x Per capita in- } \\
\text { come (EUR) }\end{array}$ & $\begin{array}{l}0.114 \\
(0.083)\end{array}$ & $\begin{array}{l}-0.008 \\
(0.065)\end{array}$ & $\begin{array}{l}-0.045 \\
(0.066)\end{array}$ & $\begin{array}{l}0.236^{*} \\
(0.130)\end{array}$ & $\begin{array}{l}0.030 \\
(0.059)\end{array}$ & $\begin{array}{l}-0.095 \\
(0.075)\end{array}$ \\
\hline $\begin{array}{l}\text { Age } \times \text { Degree share } \\
(\%)\end{array}$ & $\begin{array}{l}-0.035 \\
(0.058)\end{array}$ & $\begin{array}{l}0.091 \\
(0.083)\end{array}$ & $\begin{array}{l}0.076 \\
(0.050)\end{array}$ & $\begin{array}{l}-0.035 \\
(0.113)\end{array}$ & $\begin{array}{l}0.161 \\
(0.119)\end{array}$ & $\begin{array}{l}0.152^{* *} \\
(0.074)\end{array}$ \\
\hline $\begin{array}{l}\text { Age } \times \text { Population den- } \\
\text { sity }\left(100 \text { resid. } / \mathrm{km}^{2}\right)\end{array}$ & $\begin{array}{l}0.007 \\
(0.087)\end{array}$ & $\begin{array}{l}0.207^{* * *} \\
(0.059)\end{array}$ & $\begin{array}{l}0.165^{* * *} \\
(0.052)\end{array}$ & $\begin{array}{l}0.006 \\
(0.135)\end{array}$ & $\begin{array}{l}0.401^{* * *} \\
(0.100)\end{array}$ & $\begin{array}{l}0.272^{* * *} \\
(0.075)\end{array}$ \\
\hline $\begin{array}{l}\text { Age } x \text { Share tertiary } \\
\text { sector }(\%)\end{array}$ & $\begin{array}{l}-0.691 \\
(0.898)\end{array}$ & $\begin{array}{l}-1.164 \\
(0.914)\end{array}$ & $\begin{array}{l}-0.816 \\
(0.787)\end{array}$ & $\begin{array}{l}-1.176 \\
(1.738)\end{array}$ & $\begin{array}{l}-1.708 \\
(1.399)\end{array}$ & $\begin{array}{l}-0.809 \\
(1.110)\end{array}$ \\
\hline $\begin{array}{l}\text { Age } \times \text { Share secondary } \\
\text { sector (\%) }\end{array}$ & $\begin{array}{l}-0.644 \\
(0.884)\end{array}$ & $\begin{array}{l}-1.146 \\
(0.890)\end{array}$ & $\begin{array}{l}-0.792 \\
(0.775)\end{array}$ & $\begin{array}{l}-1.066 \\
(1.717)\end{array}$ & $\begin{array}{l}-1.694 \\
(1.365)\end{array}$ & $\begin{array}{l}-0.777 \\
(1.094)\end{array}$ \\
\hline Age x Male (\%) & & $\begin{array}{l}0.244^{* * *} \\
(0.047)\end{array}$ & $\begin{array}{l}0.090^{* *} \\
(0.040)\end{array}$ & & $\begin{array}{l}0.246^{* * *} \\
(0.053)\end{array}$ & $\begin{array}{l}0.105^{* *} \\
(0.040)\end{array}$ \\
\hline $\begin{array}{l}\text { Age } x \text { Unemployment } \\
\text { rate }(\%)\end{array}$ & & $\begin{array}{l}-0.502^{* *} \\
(0.241)\end{array}$ & $\begin{array}{l}-0.294 \\
(0.218)\end{array}$ & & $\begin{array}{l}-0.892^{* *} \\
(0.360)\end{array}$ & $\begin{array}{l}-0.381 \\
(0.301)\end{array}$ \\
\hline $\begin{array}{l}\text { Age } x \text { Homeownership } \\
\text { rate }(\%)\end{array}$ & & $\begin{array}{l}0.100^{* * *} \\
(0.027)\end{array}$ & $\begin{array}{l}0.045^{* *} \\
(0.021)\end{array}$ & & $\begin{array}{l}0.186^{* * *} \\
(0.039)\end{array}$ & $\begin{array}{l}0.090^{* * *} \\
(0.030)\end{array}$ \\
\hline $\begin{array}{l}\text { Age } \times \text { Car ownership } \\
\text { (cars per capita } \times 100 \text { ) }\end{array}$ & & $\begin{array}{l}-0.016 \\
(0.055)\end{array}$ & $\begin{array}{l}0.003 \\
(0.033)\end{array}$ & & $\begin{array}{l}0.000 \\
(0.070)\end{array}$ & $\begin{array}{l}0.035 \\
(0.037)\end{array}$ \\
\hline Age x Baden (dummy) & & & $\begin{array}{l}0.028 \\
(0.406)\end{array}$ & & & $\begin{array}{l}0.308 \\
(0.654)\end{array}$ \\
\hline $\begin{array}{l}\text { Age } x \text { Share conserva- } \\
\text { tive party (\%) }\end{array}$ & & & $\begin{array}{l}0.033 \\
(0.036)\end{array}$ & & & $\begin{array}{l}0.060 \\
(0.049)\end{array}$ \\
\hline $\begin{array}{l}\text { Age } x \text { Share green } \\
\text { party votes (\%) }\end{array}$ & & & $\begin{array}{l}0.024 \\
(0.050)\end{array}$ & & & $\begin{array}{l}0.044 \\
(0.068)\end{array}$ \\
\hline Constant & $\begin{array}{l}36.932^{* * *} \\
(0.893)\end{array}$ & $\begin{array}{l}37.342^{* * *} \\
(0.797)\end{array}$ & $\begin{array}{l}37.103^{* * *} \\
(0.577)\end{array}$ & $\begin{array}{l}37.025^{* * *} \\
(0.840)\end{array}$ & $\begin{array}{l}37.587^{* * *} \\
(0.765)\end{array}$ & $\begin{array}{l}37.200^{* * *} \\
(0.564)\end{array}$ \\
\hline Instrumental variables & - & - & - & All & All & All \\
\hline$R^{2}$ & 0.452 & 0.563 & 0.76 & 0.417 & 0.542 & 0.755 \\
\hline $\mathrm{N}$ & 1101 & 1101 & 1101 & 1101 & 1101 & 1101 \\
\hline
\end{tabular}

Notes: Unit of observation is municipalities. Industry shares are the shares of the secondary and the tertiary sectors at total employment at the county level. All variables refer to 2011, the year of the referendum, except political party shares, which stem from the 2009 federal elections. Where indicated, we use the following sets of instrumental variables: Lagged children include the share of the population below the age of six, and aged six to fifteen in 1950 and 1961. Lagged sectors include the shares of the secondary and the tertiary sectors in 1961, 1970 and 1987. Geology is a set of dummy variables each of which indicates whether a municipality is within $100 \mathrm{~km}$ of certain mine (e.g. coal). WWII is a set of dummy variables indicating deciles in the distribution of WWII destruction across municipalities. All variables are centered (zero mean). Standard errors clustered on counties. ${ }^{*} \mathrm{p}<0.1,{ }^{* *} \mathrm{p}<0.05$, $^{* * *} \mathrm{p}<0.01$. 


\section{Fig. A6. Kernel density distribution of marginal age effects}

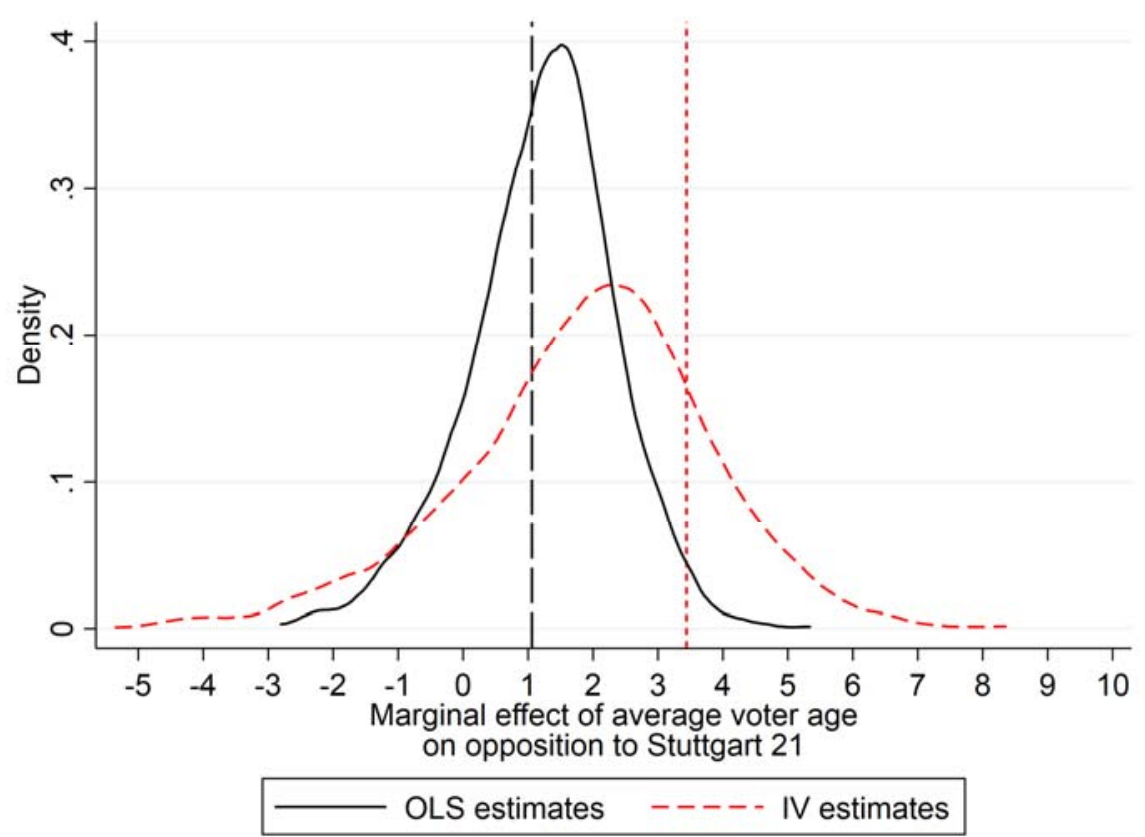

Notes: Kernel densities show the distribution of marginal effects are from Table A13, Models (2) and (5), which allow for heterogeneity in the set of preferred controls. Vertical lines indicate the OLS (long dash) and IV (short dash) estimates of the age effect from the non-interactive models in Table 2, Model (3) and Table 4, Model (5) in the main paper.

While not central to the phenomenon studied here, the estimates of the interaction effects between age and the various covariates considered in Table A13 are interesting in their own rights. Among the significant interaction effects, two are particularly interesting with respect to related literature. The baseline models suggest a relatively strong relationship between homeownership rate and support for Stuttgart 21. To the extent that Stuttgart 21 was expected to increase property prices, this empirical relationship can be rationalized with an asset gain or wealth motive as discussed in the literature on the homevoter hypothesis (Ahlfeldt and Maennig, 2015; Dehring et al., 2008; Fischel, 2001). The positive interaction effect between the homeownership rate and average age suggests that it is particularly the young homeowners who vote according to such a wealth motive. This is intuitive since younger homeowners, during their remaining lifetime, are more likely to sell their property.

The other interesting effect is the positive interaction between the average age and the share of male voters. The fact that the age effect is driven particularly by male voters is consistent with behavioral economics results suggesting that women are more altruistic, especially if altruism is expensive (Andreoni and Vesterlund, 2001). 
More specific to the present context, the negative coefficient on the age $\mathrm{x}$ unemployment rate interaction suggests that younger voters (relative to older voters) are less supportive of the Stuttgart 21 project if there is high unemployment. This is in line with non-commuters attaching a lower value to transport infrastructures. In contrast, the age-related polarization of attitudes towards Stuttgart 21 is particularly large in denser municipalities. One way to rationalize this pattern is that younger voters in denser cities are less car dependent (Ahlfeldt \& Pietrostefani, 2017) and therefore more open to alternative modes of transportation.

\section{Life expectancy effects}

In Tables A14 and A15 we replicate our baseline models from Table 2 in the main paper adding a control for either life expectancy at the age of 60 (Table A14) or life expectancy at birth (Table A15). We note that regionally varying life expectancy data are only available at the level of counties. Therefore, we cluster standard errors at that level. Without further controls, we find a positive effect of life expectancy on opposition to Stuttgart 21 (Column 1 in both tables). This result is not economically intuitive because a larger remaining lifetime should improve the expected benefit cost ratio of an individual. The life expectancy effect, however, becomes quantitatively and statistically insignificant once we add controls, suggesting that the counter-intuitive effect in the baseline model is driven by correlated individual characteristics.

Interestingly, we find a positive effect of life expectancy on turnout, even conditional on controls. However, controlling for turnout (using turnout in a past federal election as an IV) does not qualitatively affect the results as in Table 3 in the main paper. The age effect remains almost unchanged and the life expectancy is either (counter-intuitively) positive or insignificant as in Tables A14 and A15 (results are not reported here to keep the presentation compact). Across all estimated models, the estimated age effects are not particularly sensitive to controlling for life expectancy.

Overall, the evidence suggests that conditional on controlling for average age, life expectancy does not have a significant impact on the voting decisions in the referendum. Either voters are not fully aware of their regionally varying life expectancy, or they value the final years of their life relatively low so that a larger remaining lifetime, conditional on their age, has a marginal impact on voting decisions only. 
Tab A14. Determinants of opposition to Stuttgart 21: Baseline models controlling for life
expectancy at the age of 60

\begin{tabular}{|c|c|c|c|c|c|c|}
\hline & $\begin{array}{l}\text { (1) } \\
\text { Share yes } \\
\text { votes (\%) }\end{array}$ & $\begin{array}{l}(2) \\
\text { Share yes } \\
\text { votes (\%) }\end{array}$ & $\begin{array}{l}(3) \\
\text { Share yes } \\
\text { votes (\%) }\end{array}$ & $\begin{array}{l}(4) \\
\text { Share yes } \\
\text { votes (\%) }\end{array}$ & $\begin{array}{l}\text { (5) } \\
\text { Turnout } \\
\text { (\%) }\end{array}$ & $\begin{array}{l}6) \\
\text { Turnout } \\
\text { (\%) }\end{array}$ \\
\hline Average age (years) & $\begin{array}{l}1.572^{* * *} \\
(0.458)\end{array}$ & $\begin{array}{l}1.498^{* * *} \\
(0.345)\end{array}$ & $\begin{array}{l}1.061^{* * *} \\
(0.291)\end{array}$ & $\begin{array}{l}0.704^{* * *} \\
(0.183)\end{array}$ & $\begin{array}{l}-0.074 \\
(0.231)\end{array}$ & $\begin{array}{l}0.195 \\
(0.223)\end{array}$ \\
\hline $\begin{array}{l}\text { Distance from Stuttgart } \\
(\mathrm{km})\end{array}$ & $\begin{array}{l}0.081^{* * *} \\
(0.0176)\end{array}$ & $\begin{array}{l}0.123^{* * *} \\
(0.0166)\end{array}$ & $\begin{array}{l}0.109^{* * *} \\
(0.0177)\end{array}$ & $\begin{array}{l}0.078^{* * *} \\
(0.0115)\end{array}$ & $\begin{array}{l}-0.156^{* * *} \\
(0.0139)\end{array}$ & \\
\hline $\begin{array}{l}\text { Remaining life expectancy } \\
\text { at } 60 \text { (years) }\end{array}$ & $\begin{array}{l}5.295^{* * *} \\
(1.886)\end{array}$ & $\begin{array}{l}-0.084 \\
(1.490) \\
\end{array}$ & $\begin{array}{l}-0.108 \\
(1.618)\end{array}$ & $\begin{array}{l}-1.917^{*} \\
(1.000) \\
\end{array}$ & $\begin{array}{l}7.043^{* * *} \\
(1.732)\end{array}$ & $\begin{array}{l}4.438^{* *} \\
(1.699)\end{array}$ \\
\hline Controls & & $\begin{array}{l}\text { Parsimoni- } \\
\text { ous }\end{array}$ & Preferred & Demanding & Preferred & Demanding \\
\hline$R^{2}$ & 0.235 & 0.443 & 0.528 & 0.755 & 0.614 & 0.562 \\
\hline $\mathrm{N}$ & 1101 & 1101 & 1101 & 1101 & 1101 & 1101 \\
\hline
\end{tabular}

Notes: Unit of observation is municipalities. Parsimonious controls include the respondent's geographical distance to Stuttgart, the household income and the educational status. Preferred controls, in addition, include unemployment, homeownership, the number of registered cars per capita, and the county-level shares of the secondary and tertiary sectors at total employment. Demanding controls, in addition, include share of Green party votes in the 2009 federal elections, share of conservative party votes in the same elections, and an indicator variable denoting Baden. Standard errors in parentheses are clustered on counties (life expectancy is available at this level). ${ }^{*} p<0.10,{ }^{* *} p<0.05,{ }^{* * *} p<0.01$

\section{Tab A15. Determinants of opposition to Stuttgart 21: Baseline models controlling for life expectancy at birth}

\begin{tabular}{|c|c|c|c|c|c|c|}
\hline & (1) & $(2)$ & (3) & (4) & (5) & (6) \\
\hline & $\begin{array}{l}\text { Share yes } \\
\text { votes (\%) }\end{array}$ & $\begin{array}{l}\text { Share yes } \\
\text { votes (\%) }\end{array}$ & $\begin{array}{l}\text { Share yes } \\
\text { votes (\%) }\end{array}$ & $\begin{array}{l}\text { Share yes } \\
\text { votes (\%) }\end{array}$ & Turnout (\%) & Turnout (\%) \\
\hline Average age (years) & $\begin{array}{l}1.521^{* * *} \\
(0.463)\end{array}$ & $\begin{array}{l}1.483^{* * *} \\
(0.353)\end{array}$ & $\begin{array}{l}1.045^{* * *} \\
(0.297)\end{array}$ & $\begin{array}{l}0.700^{* * *} \\
(0.185)\end{array}$ & $\begin{array}{l}-0.088 \\
(0.250)\end{array}$ & $\begin{array}{l}0.172 \\
(0.224)\end{array}$ \\
\hline $\begin{array}{l}\text { Distance from Stuttgart } \\
(\mathrm{km})\end{array}$ & $\begin{array}{l}0.091^{* * *} \\
(0.0163)\end{array}$ & $\begin{array}{l}0.122^{* * *} \\
(0.0168)\end{array}$ & $\begin{array}{l}0.109^{* * *} \\
(0.0186)\end{array}$ & $\begin{array}{l}0.074^{* * *} \\
(0.0120)\end{array}$ & $\begin{array}{l}-0.143^{* * *} \\
(0.0161)\end{array}$ & \\
\hline $\begin{array}{l}\text { Life expectancy at birth } \\
\text { (years) }\end{array}$ & $\begin{array}{l}4.951^{* * *} \\
(1.199)\end{array}$ & $\begin{array}{l}0.703 \\
(1.288) \\
\end{array}$ & $\begin{array}{l}0.587 \\
(1.243)\end{array}$ & $\begin{array}{l}-0.890 \\
(0.707) \\
\end{array}$ & $\begin{array}{l}4.039^{* * *} \\
(1.204)\end{array}$ & $\begin{array}{l}3.353^{* * *} \\
(1.142)\end{array}$ \\
\hline Controls & - & $\begin{array}{l}\text { Parsimoni- } \\
\text { ous }\end{array}$ & Preferred & Demanding & Preferred & Demanding \\
\hline $\mathrm{R}^{2}$ & 0.142 & 0.264 & 0.497 & 0.743 & 0.563 & 0.674 \\
\hline $\mathrm{N}$ & 1101 & 1101 & 1101 & 1101 & 1101 & 1101 \\
\hline
\end{tabular}

Notes: Unit of observation is municipalities. Parsimonious controls include distance from Stuttgart 21, the share of male voters, share of degree holders, and income. Parsimonious controls include the respondent's geographical distance to Stuttgart, the household income and the educational status. Preferred controls, in addition, include unemployment, homeownership, the number of registered cars per capita, and the county-level shares of the secondary and tertiary sectors at total employment. Demanding controls, in addition, include share of Green party votes in the 2009 federal elections, share of conservative party votes in the same elections, and an indicator variable denoting Baden. Standard errors in parentheses are clustered on counties (life expectancy is available at this level). ${ }^{*} p<0.10,{ }^{* *} p<0.05,{ }^{* * *} p<0.01$

\section{Complementary survey microdata analysis}

The notorious concern in cross-sectional regression analyses is that there are unobserved confounders that are correlated with the variable of interest (see Section A4.2 of this appendix for a 
more detailed discussion). Area-based analyses are particularly prone to bias due to sorting since unobserved locational characteristics are likely to attract certain types of residents with characteristics that are difficult to observe and control for.

To address this concern, we conduct a complementary analysis of post-election survey data. Such data arguably represents the best proxy for individual-level voting decisions that are accessible to researches, given the intrinsic confidentiality of ballot votes. We use a data set that emerged from three connected studies exploring the 2011 state election in Baden-Württemberg, the Stuttgart 21 referendum, and a more generic study on the nature of public participation and direct democracy in Baden-Württemberg (for details, see Blumenberg, 2017). We restrict the data analyzed to survey waves that were conducted in the immediate aftermath of the referendum (between $28^{\text {th }}$ November and $14^{\text {th }}$ December, 2011). The dependent variable tested is a binary code reflecting the individual respondent's personal attitude towards Stuttgart 21 project (support/opposition).

In our analysis of the survey data we explore a binary dependent variable that summarizes whether or not an interviewee was generally in support of the Stuttgart 21 project. The explanatory variables included are substantively the same as the ones used in baseline models reported in the main paper. ${ }^{4}$ We closely follow the strategy used in the main paper (and motivated in detail in Section A4.2) and consider three sets of covariates. The basic controls include the distance from Stuttgart to a respondent's residence, the household income as well as the educational status. In an extended specification, we add controls for gender and employment status. A further extended specification controls for the political party supported in the previous state election and an indicator for whether a respondent lives in Baden. We use these three distinct sets of covariates in linear probability models, which are conceptionally similar to the models estimated in the main paper. Given the binary nature of the outcome variable, we also estimate logit models for which we report the marginal effects at the mean of the age distribution.

Table A16 below summarizes the results. Confirming the results using regional data in the main paper, we find a positive and highly statistically significant effect of age on opposition to Stuttgart 21 in all specifications. Measured at the level of an individual voter, an increase in voter age by one year is associated with an about half percentage point greater propensity of opposing the project.

4 As access to the survey data is restricted, estimations were executed by Dr. Johannes Blumenberg of the GESIS Leibniz Institute for the Social Science, Mannheim based on scripts and specifications provided by the authors. We would kindly like to thank Dr. Blumenberg for his assistance. 
While the point estimate is somewhat lower than the age effects reported in the main paper, there is also naturally more variance in the distribution of age across individuals (the unit of observation in the table below) than in the distribution of the average age across municipalities (the unit of observation in the main paper). So, the smaller coefficient on age by no means implies that the age effect is quantitatively smaller.

Tab A16. Determinants of opposition to Stuttgart 21: Individual level models

\begin{tabular}{lllllll}
\hline & $(1)$ & $(2)$ & $(3)$ & $(4)$ & $(5)$ & $(6)$ \\
\cline { 2 - 7 } & Opposition & Opposition & Opposition & Opposition & Opposition & Opposition \\
\cline { 2 - 7 } & OLS & LOGIT & OLS & LOGIT & OLS & LOGIT \\
\hline Age & $0.412^{* * *}$ & $0.540^{* * *}$ & $0.500^{* * *}$ & $0.484^{* * *}$ & $0.619^{* * *}$ & $0.554^{* * *}$ \\
& $(0.142)$ & $(0.133)$ & $(0.123)$ & $(0.103)$ & $(0.125)$ & $(0.118)$ \\
\hline Controls & Parsimonious & Parsimonious & Preferred & Preferred & Demanding & Demanding \\
\hline (Pseudo) $\mathrm{R}^{2}$ & 0.040 & 0.029 & 0.046 & 0.033 & 0.255 & 0.190 \\
\hline
\end{tabular}

Notes: Unit of observation is individual survey responses. In total, we observe about 1,200 expressions of support (dependent variable $=0$ ) or opposition (dependent variable $=1$ ). The number of observations varies slightly from model to model due to missing values. The estimation method is OLS/linear probability (columns 1, 3, and 5) respectively LOGIT (columns 2, 4 and 6). Marginal effects at the mean of the age distribution reported for LOGIT specifications. Parsimonious controls include the respondent's geographical distance to Stuttgart, the household income and the educational status. Preferred controls, in addition, include gender and employment status. Full controls, in addition, include residence in the Baden region and preferences for political parties. Point estimates and standard errors (in parentheses) are multiplied by 100 to allow for direct comparability to the results reported in the main paper. ${ }^{*} p<0.1,{ }^{* *} p<0.05,{ }^{* * *} p<0.01$.

\section{Literature}

Ahlfeldt, G. M., and Maennig, W. (2015). Homevoters vs. leasevoters: A spatial analysis of airport effects. Journal of Urban Economics, 87, 85-99.

Ahlfeldt, G. M., and Pietrostefani, E. (2017). The economic effects of density: A synthesis. CESifo Working Paper Series No. 6744.

Ahlfeldt, G. M., Redding, S. J., Sturm, D. M., and Wolf, N. (2015). The Economics of Density: Evidence from the Berlin Wall. Econometrica, 83(6), 2127-2189.

Andreoni, J., and Vesterlund, L. (2001). Which is the Fair Sex? Gender Differences in Altruism. The Quarterly Journal of Economics, 116(1), 293-312.

Angrist, J. D., and Pischke, J.-S.. (2009). Mostly Harmless Econometrics: An Empiricist's Companion. Princeton, New Jersey: Princeton University Press.

Bahnprojekt Stuttgart-Ulm. (2018). Die Finanzierung Neuordnung Bahnknoten Stuttgart (S21). Retrieved from http://www.bahnprojekt-stuttgart-ulm.de/projekt/finanzierung-undkosten/s21-neuordnung-bahnknoten-stuttgart/finanzierung/

Bardua, H. (1975). Kriegsschäden in Baden-Württemberg 1939-1945. In: Kommission für geschichtliche Landeskunde in Baden-Württemberg, Historischer Atlas von BadenWürttemberg 1975. Stuttgart.

Baumgarten, B., and Rucht, D. (2013). Die Protestierenden gegen „Stuttgart 21“ - einzigartig oder typisch? In F. Brettschneider \& W. Schuster (Eds.), Stuttgart 21 Ein Großprojekt zwischen Protest und Akzeptanz (pp. 15-76). Wiesbaden: Springer VS.

Blumenberg, J. N. (2017). Wutbürger für immer - wirklich? Informationsdienst Soziale Indikatoren ISI, 58, 6-12.

Brakman, S., Garretsen, H., and Schramm, M. (2004). The strategic bombing of German cities during World War II and its impact on city growth. Journal of Economic Geography, 4(2), 201-218.

Buchenau, M.-W. (2018). Enge im Stadtkessel und schlechte Luft - das reiche Stuttgart ist arm an Wohnraum.

Handelsblatt,

July

09.

Retrieved

from 
https://www.handelsblatt.com/finanzen/immobilien/trendviertel/trendviertel-2018enge-im-stadtkessel-und-schlechte-luft-das-reiche-stuttgart-ist-arm-anwohnraum/22781006.html

Bündnis 90 Die Grünen. (2010). Stuttgart 21 stoppen! Retrieved from https://www.gruene.de/fileadmin/user upload/Dokumente/Sonstiges/S21-Stoppen.pdf

Conley, T. G. (1999). GMM estimation with cross sectional dependence. Journal of Econometrics, 92(1), 1-45.

Dehring, C. A., Depken, C. A., and Ward, M. R. (2008). A direct test of the homevoter hypothesis. Journal of Urban Economics, 64(1), 155-170.

Fernihough, A., and O'Rourke, K. H. (2014). Coal and the European Industrial Revolution. NBER Working Paper 19802.

Fischel, W. A. (2001). The Homevoter Hypothesis. Cambridge, MA: Harvard University Press.

Glaeser, E. L., Kallal, H. D., Scheinkman, J. A., and Shleifer, A. (1992). Growth in Cities. Journal of Political Economy, 100(6), 1126-1152.

Henderson, V., Kuncoro, A., and Turner, M. (1995). Industrial Development in Cities. Journal of Political Economy, 103(5), 1067-1090.

Höhn, T., and Obergassner, P. (2018). Immobilienmarkt in der Region Stuttgart - Vielen bleibt nur die Flucht in die Miete. Stuttgarter Zeitung, August 02. Retrieved from: https://www.stuttgarter-zeitung.de/inhalt.immobilienmarkt-in-ludwigsburg-und-regionvielen-bleibt-nur-die-flucht-in-die-miete.b6c351bb-bd94-4873-8cae-f82bb4a28c74.html

Kröger, M. (2010). Was für "Stuttgart 21" spricht - und was dagegen. Spiegel Online, September 08.

Kurbjuweit, D. (2010). Der Wutbürger. Der Spiegel, 41, October 11, 26-27.

Lumme, C. (2010). Stuttgart 21: Warum die Rentner auf die Straße gehen. Westdeutsche Zeitung.

Mohammed, S. I., and Williamson, J. G. (2004). Freight rates and productivity gains in British tramp shipping 1869-1950. Explorations in Economic History, 41, 172-203.

Reimann, A. (2010). Rebellische Rentner - Aufstand der Silberköpfe. Spiegel Online, October 17. Retrieved from http://www.spiegel.de/politik/deutschland/rebellische-rentner-aufstandder-silberkoepfe-a-723053.html

Schubert, D. (1990). Planer-Vorschlag: Neue Stadt über Bahnhofstunnel. Stuttgarter Zeitung, October 10.

SMA und Partner AG. (2010). Stuttgart 21 und Kopfbahnhof 21: Vergleichende Analyse der Reisezeiten. Zurich.

Stuckenbrock, U. (2013). Das Projekt "Stuttgart 21" im zeitlichen Überblick. In F. Brettschneider \& W. Schuster (Eds.), Stuttgart 21 Ein Großprojekt zwischen Protest und Akzeptanz (pp. 15-76). Wiesbaden: Springer VS.

The World Bank. (2015). World development indicators. Washington, D.C.: The World Bank.

Wagschal, U. (2013). Die Volksabstimmung zu Stuttgart 21 - ein direktdemokratisches Lehrstück? In U. Wagschal, U. Eith, \& M. Wehner (Eds.), Der historische Machtwechsel: Grün-rot in BadenWürttemberg (pp. 181-205). Berlin: Nomos.

Winkelmann, U. (2013). Berufspendler in Baden-Württemberg. Statistishes Monatsheft BadenWürttemberg, November 2013, 25-29. 


\section{Appendix II: \\ Direct democracy and intergenerational conflicts in aging societies}

Version: December 2018

\section{Introduction}

This web appendix complements the quantitative literature review in the main paper (Section 3). Table A1 in Section 2 of this web appendix presents details of the reviewed referendums which are not reported in the main paper due to space constraints. Section 3 describes a back of the envelope calculation to approximate the total turnout covered in all included referendums. Section 4 discusses how we selected the unambiguous sample used in Table 7, Column (5) in the main paper. Section 5 presents the results of empirical models that complement Table 7 in the main paper. The reference section provides full bibliographic details of the studies reviewed.

\section{Summary of referendums analyzed}

In Table A1 we list the topic of each referendum, the category to which it is assigned, and the type of age variable considered by the authors. The next columns summarize the elderly attitude, beginning with whether the elderly supported or opposed a proposal (if the age effect is significant). We also report how we encode the elderly attitude with respect to individualistic, neutral or collectivistic (applying the rules described in Table 6 in the main paper) and the status quo of the political framework. Referendum-specific considerations are reported as notes in the last column. 
Tab A1. Summary of referendums analyzed

\begin{tabular}{|c|c|c|c|c|c|c|c|c|c|c|}
\hline$\#$ & ID & Year & Author & Category & Referendum & Age variable ${ }^{a}$ & & Attitude $^{\mathrm{b}}$ & & Note \\
\hline 1 & 1 & 1977 & Rubinfeld & $\begin{array}{c}\text { School } \\
\text { spending }\end{array}$ & $\begin{array}{l}\text { Renewal of school taxes in } \\
\text { Troy, Michigan, May election }\end{array}$ & $\begin{array}{l}\text { Having children in } \\
\text { school }\end{array}$ & Opposition & Individualistic & Change & $\begin{array}{l}\text { Not having school-aged chil- } \\
\text { dren (correlated with age) }\end{array}$ \\
\hline 2 & 1 & 1977 & Rubinfeld & $\begin{array}{l}\text { School } \\
\text { spending }\end{array}$ & $\begin{array}{l}\text { Renewal of school taxes in } \\
\text { Troy, Michigan, June election }\end{array}$ & $\begin{array}{l}\text { Having children in } \\
\text { school }\end{array}$ & Opposition & Individualistic & Change & $\begin{array}{c}\text { leads to opposition to renewal } \\
\text { of school taxes. }\end{array}$ \\
\hline 3 & 2 & 1979 & Fischel & $\begin{array}{c}\text { Urban } \\
\text { development }\end{array}$ & $\begin{array}{l}\text { New pulp mill in New Hamp- } \\
\text { shire }\end{array}$ & $\begin{array}{c}\text { Share of retired } \\
\text { population and av- } \\
\text { erage age }\end{array}$ & $\begin{array}{l}\text { Not signifi- } \\
\text { cant }\end{array}$ & Neutral & Neutral & $\begin{array}{l}\text { Retired and age effects tend to } \\
\text { cancel each other out. }\end{array}$ \\
\hline 4 & 3 & 1982 & Noam & Welfare & $\begin{array}{l}\text { Unemployment benefits, not } \\
\text { specified further }\end{array}$ & Age & $\begin{array}{c}\text { Not } \\
\text { significant }\end{array}$ & Neutral & Neutral & \multirow{12}{*}{$\begin{array}{l}\text { This study assumes that age is } \\
\text { a covariate in all analyses of } \\
\text { referendums, but is reported } \\
\text { only where significant. The } \\
\text { number of children is signifi- } \\
\text { cant in some referendums. Be- } \\
\text { cause the age of children is not } \\
\text { specified, it is not possible to } \\
\text { infer an elderly effect. }\end{array}$} \\
\hline 5 & 3 & 1982 & Noam & $\begin{array}{l}\text { Health ser- } \\
\text { vices }\end{array}$ & $\begin{array}{c}\text { Hospitals, not specified fur- } \\
\text { ther }\end{array}$ & Age & Support & Individualistic & Status quo & \\
\hline 6 & 3 & 1982 & Noam & Welfare & $\begin{array}{l}\text { Welfare subsidies, not speci- } \\
\text { fied further }\end{array}$ & Age & $\begin{array}{c}\text { Not } \\
\text { significant }\end{array}$ & Neutral & Neutral & \\
\hline 7 & 3 & 1982 & Noam & Transportation & $\begin{array}{c}\text { Highways, not specified fur- } \\
\text { ther }\end{array}$ & Age & Opposition & Individualistic & Status quo & \\
\hline 8 & 3 & 1982 & Noam & Transportation & $\begin{array}{l}\text { Mass transit, not specified } \\
\text { further }\end{array}$ & Age & Support & Collectivistic & Change & \\
\hline 9 & 3 & 1982 & Noam & $\begin{array}{l}\text { Law enf. \& de- } \\
\text { fense }\end{array}$ & $\begin{array}{c}\text { Prosecutor, not specified fur- } \\
\text { ther }\end{array}$ & Age & $\begin{array}{c}\text { Not } \\
\text { significant }\end{array}$ & Neutral & Neutral & \\
\hline 10 & 3 & 1982 & Noam & Infrastructure & Prison, not specified further & Age & $\begin{array}{c}\text { Not } \\
\text { significant }\end{array}$ & Neutral & Neutral & \\
\hline 11 & 3 & 1982 & Noam & $\begin{array}{l}\text { Health } \\
\text { services }\end{array}$ & $\begin{array}{c}\text { Old-aged home, not specified } \\
\text { further }\end{array}$ & Age & Support & Individualistic & Status quo & \\
\hline 12 & 3 & 1982 & Noam & $\begin{array}{l}\text { Sports } \\
\text { facility }\end{array}$ & $\begin{array}{l}\text { Sports facilities, not specified } \\
\text { further }\end{array}$ & Age & $\begin{array}{c}\text { Not } \\
\text { significant }\end{array}$ & Neutral & Neutral & \\
\hline 13 & 3 & 1982 & Noam & Culture & $\begin{array}{c}\text { Museum, not specified fur- } \\
\text { ther }\end{array}$ & Age & $\begin{array}{c}\text { Not } \\
\text { significant }\end{array}$ & Neutral & Neutral & \\
\hline 14 & 3 & 1982 & Noam & $\begin{array}{l}\text { School } \\
\text { spending }\end{array}$ & $\begin{array}{l}\text { Educational expenditure, not } \\
\text { specified further }\end{array}$ & Age & $\begin{array}{c}\text { Not } \\
\text { significant }\end{array}$ & Neutral & Neutral & \\
\hline 15 & 3 & 1982 & Noam & Foreign aid & $\begin{array}{c}\text { Foreign aid, not specified fur- } \\
\text { ther }\end{array}$ & Age & $\begin{array}{c}\text { Not } \\
\text { significant }\end{array}$ & Neutral & Neutral & \\
\hline
\end{tabular}




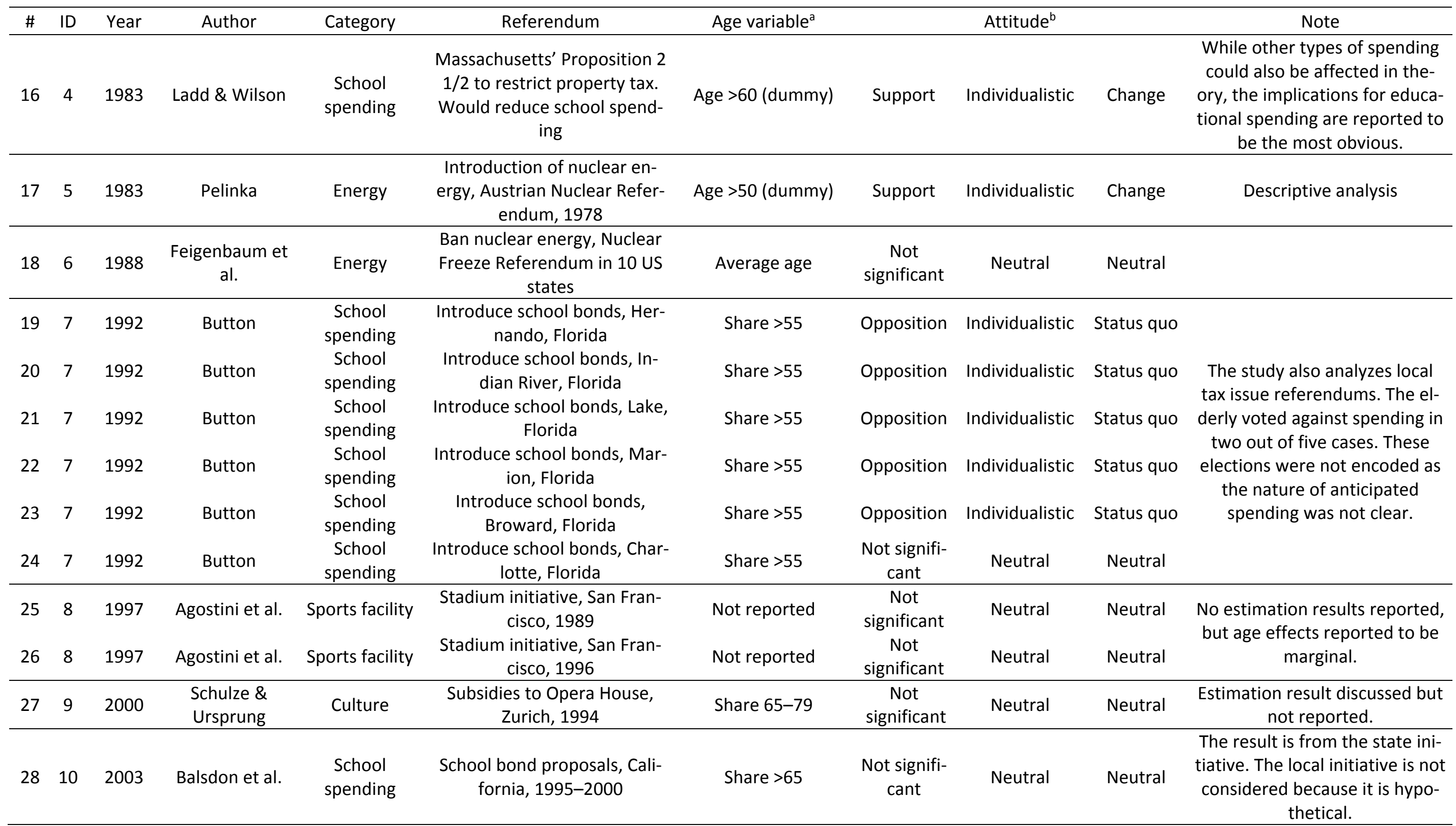




\begin{tabular}{|c|c|c|c|c|c|c|c|c|c|c|}
\hline$\#$ & ID & Year & Author & Category & Referendum & Age variable ${ }^{a}$ & & Attitude $^{b}$ & & Note \\
\hline 29 & 11 & 2004 & $\begin{array}{c}\text { Brunner \& } \\
\text { Balsdon }\end{array}$ & $\begin{array}{c}\text { School } \\
\text { spending }\end{array}$ & $\begin{array}{c}\text { School bond, Proposition 47, } \\
\text { California, } 2002\end{array}$ & Dummy >55 & Opposition & Individualistic & Status quo & \multirow{4}{*}{$\begin{array}{l}\text { This study analyzes the same } \\
\text { referendums as Bornstein \& } \\
\text { Lanz (2008) }\end{array}$} \\
\hline 30 & 12 & 2004 & Thalmann & Energy & $\begin{array}{c}\text { Green tax reform, Switzer- } \\
\text { land, } 2000\end{array}$ & Dummy >60 & Opposition & Individualistic & Status quo & \\
\hline 31 & 12 & 2004 & Thalmann & Energy & $\begin{array}{c}\text { Energy conservation package, } \\
\text { Switzerland, } 2000\end{array}$ & Dummy >60 & Opposition & Individualistic & Status quo & \\
\hline 32 & 12 & 2004 & Thalmann & Energy & $\begin{array}{c}\text { Solar initiative, Switzerland, } \\
2000\end{array}$ & Dummy >60 & Opposition & Individualistic & Status quo & \\
\hline 33 & 13 & 2005 & Hobolt & Integration & EMU, Denmark, 2000 & Age & $\begin{array}{c}\text { Not } \\
\text { significant }\end{array}$ & Neutral & Neutral & \\
\hline 34 & 13 & 2005 & Hobolt & Integration & EC Accession, Norway, 1972 & Age & $\begin{array}{c}\text { Not } \\
\text { significant }\end{array}$ & Neutral & Neutral & \\
\hline 35 & 13 & 2005 & Hobolt & Integration & Nice Treaty, Ireland, 2002 & Age & $\begin{array}{c}\text { Not } \\
\text { significant }\end{array}$ & Neutral & Neutral & \\
\hline 36 & 13 & 2005 & Hobolt & Integration & EU Accession, Norway, 1994 & Age & $\begin{array}{c}\text { Not } \\
\text { significant }\end{array}$ & Neutral & Neutral & \\
\hline 37 & 13 & 2005 & Hobolt & Integration & Nice Treaty, Ireland, 2001 & Age & $\begin{array}{c}\text { Not } \\
\text { significant }\end{array}$ & Neutral & Neutral & \\
\hline 38 & 13 & 2005 & Hobolt & Integration & $\begin{array}{c}\text { Maastricht Treaty, Denmark, } \\
1992\end{array}$ & Age & $\begin{array}{c}\text { Not } \\
\text { significant }\end{array}$ & Neutral & Neutral & \\
\hline 39 & 13 & 2005 & Hobolt & Integration & EC Accession, Denmark, 1972 & Age & $\begin{array}{c}\text { Not } \\
\text { significant }\end{array}$ & Neutral & Neutral & \\
\hline 40 & 13 & 2005 & Hobolt & Integration & $\begin{array}{c}\text { Maastricht Treaty, Denmark, } \\
1993\end{array}$ & Age & $\begin{array}{c}\text { Not } \\
\text { significant }\end{array}$ & Neutral & Neutral & \\
\hline 41 & 14 & 2005 & Rushton & Culture & $\begin{array}{c}\text { Increase in property taxes } \\
\text { with proceeds earmarked for } \\
\text { culture, Detroit, } 2002\end{array}$ & Share $>65$ & $\begin{array}{l}\text { Not } \\
\text { significant }\end{array}$ & Neutral & Neutral & \\
\hline 42 & 15 & 2006 & $\begin{array}{c}\text { Coates \& } \\
\text { Humphreys }\end{array}$ & Sports facility & $\begin{array}{l}\text { Football stadium in Green } \\
\text { Bay, Wisconsin } 2000\end{array}$ & Share $>65$ & $\begin{array}{c}\text { Not } \\
\text { significant }\end{array}$ & Neutral & Neutral & \\
\hline 43 & 15 & 2006 & $\begin{array}{l}\text { Coates \& } \\
\text { Humphreys }\end{array}$ & Sports facility & $\begin{array}{c}\text { Basketball arena in Houston, } \\
\text { Texas, } 1999\end{array}$ & Share $>65$ & $\begin{array}{c}\text { Not } \\
\text { significant }\end{array}$ & Neutral & Neutral & \\
\hline 44 & 15 & 2006 & $\begin{array}{c}\text { Coates \& } \\
\text { Humphreys }\end{array}$ & Sports facility & $\begin{array}{c}\text { Basketball arena in Houston, } \\
\text { Texas, } 2000\end{array}$ & Share $>65$ & Opposition & Individualistic & Status quo & \\
\hline
\end{tabular}




\begin{tabular}{|c|c|c|c|c|c|c|c|c|c|c|}
\hline$\#$ & ID & Year & Author & Category & Referendum & Age variable ${ }^{a}$ & & Attitude $^{b}$ & & Note \\
\hline 45 & 16 & 2006 & $\begin{array}{l}\text { Kotchen \& } \\
\text { Powers }\end{array}$ & $\begin{array}{c}\text { Urban } \\
\text { development }\end{array}$ & $\begin{array}{c}857 \text { pooled US referendums } \\
\text { on open-space conservation, } \\
\text { US, 1998-2003 }\end{array}$ & Share $>65$ & Support & Individualistic & Change & \\
\hline 46 & 16 & 2006 & $\begin{array}{l}\text { Kotchen \& } \\
\text { Powers }\end{array}$ & $\begin{array}{c}\text { Urban } \\
\text { development }\end{array}$ & $\begin{array}{c}\text { Open-space conservation, } \\
\text { New Jersey }\end{array}$ & Share $>65$ & Support & Individualistic & Change & \multirow[b]{2}{*}{$\begin{array}{c}\text { The effect is not significant in } \\
\text { all models, but is qualitatively } \\
\text { consistent. }\end{array}$} \\
\hline 47 & 16 & 2006 & $\begin{array}{l}\text { Kotchen \& } \\
\text { Powers }\end{array}$ & $\begin{array}{c}\text { Urban } \\
\text { development }\end{array}$ & $\begin{array}{c}\text { Open-space conservation, } \\
\text { Massachusetts }\end{array}$ & Share $>65$ & Opposition & Collectivistic & Status quo & \\
\hline 48 & 17 & 2007 & Dehring et al. & Transportation & $\begin{array}{l}\text { Sales tax increase for mass } \\
\text { transit and street mainte- } \\
\text { nance, Arlington, May } 2002\end{array}$ & Share $>65$ & $\begin{array}{l}\text { Not signifi- } \\
\text { cant (in } \\
\text { two out of } \\
\text { three mod- } \\
\quad \text { els) }\end{array}$ & Neutral & Neutral & \multirow{3}{*}{$\begin{array}{l}\text { This is the same study as the } \\
\text { JUE publication, but the results } \\
\text { of the complementary analysis } \\
\text { of the transportation referen- } \\
\text { dums are reported only in the } \\
\text { WP. }\end{array}$} \\
\hline 49 & 17 & 2007 & Dehring et al. & Transportation & $\begin{array}{l}\text { Sales tax increase for mass } \\
\text { transit and street mainte- } \\
\text { nance, Arlington, Feb. } 2003\end{array}$ & Share $>65$ & Opposition & Individualistic & Status quo & \\
\hline 50 & 17 & 2007 & Dehring et al. & Transportation & $\begin{array}{c}\text { Sales tax increase for mass } \\
\text { transit and street mainte- } \\
\text { nance, Arlington, Nov. } 2003\end{array}$ & Share $>65$ & $\begin{array}{c}\text { Not } \\
\text { significant }\end{array}$ & Neutral & Neutral & \\
\hline 52 & 18 & 2008 & $\begin{array}{l}\text { Bornstein \& } \\
\quad \text { Lanz }\end{array}$ & Energy & $\begin{array}{l}\text { Energy conservation package, } \\
\text { Switzerland, } 2000\end{array}$ & Share $>60$ & Opposition & Individualistic & Status quo & \multirow{2}{*}{$\begin{array}{l}\text { This study analyzes the same } \\
\text { referendums as Thalmann } \\
\text { (2004). The solar initiative ef- } \\
\text { fect is not significant in all } \\
\text { models, but is qualitatively } \\
\text { consistent. }\end{array}$} \\
\hline 53 & 18 & 2008 & $\begin{array}{c}\text { Bornstein \& } \\
\quad \text { Lanz }\end{array}$ & Energy & $\begin{array}{l}\text { Solar initiative, Switzerland, } \\
2000\end{array}$ & Share $>60$ & Opposition & Individualistic & Status quo & \\
\hline 54 & 19 & 2008 & Dehring et al. & Sports facility & $\begin{array}{l}\text { Subsidized football stadium, } \\
\text { Arlington, Texas, } 2004\end{array}$ & Share $>65$ & $\begin{array}{c}\text { Not } \\
\text { significant }\end{array}$ & Neutral & Neutral & \\
\hline 55 & 20 & 2009 & Ahlfeldt et al. & Integration & EMU, Sweden 2003 & Average age & Opposition & Individualistic & Status quo & \\
\hline 56 & 20 & 2009 & Ahlfeldt et al. & Integration & $\begin{array}{l}\text { EU membership, Sweden, } \\
1994\end{array}$ & Average age & Opposition & Individualistic & Status quo & \\
\hline 57 & 20 & 2009 & Ahlfeldt et al. & Integration & EMU, Denmark, 2000 & Average age & Opposition & Individualistic & Status quo & \\
\hline 58 & 21 & 2010 & Banzhaf et al. & $\begin{array}{c}\text { Urban } \\
\text { development }\end{array}$ & $\begin{array}{l}\text { Land conservation referen- } \\
\text { dums, pooled, US, 1998-2006 }\end{array}$ & Share $>65$ & $\begin{array}{c}\text { Not } \\
\text { significant }\end{array}$ & Neutral & Neutral & \\
\hline
\end{tabular}




\begin{tabular}{|c|c|c|c|c|c|c|c|c|c|c|}
\hline$\#$ & ID & Year & Author & Category & Referendum & Age variable $^{a}$ & & Attitude $^{b}$ & & Note \\
\hline 59 & 22 & 2010 & $\begin{array}{l}\text { Brunner \& } \\
\text { Ross }\end{array}$ & $\begin{array}{l}\text { School } \\
\text { spending }\end{array}$ & $\begin{array}{l}\text { Lowering the required share } \\
\text { for passing educational bond } \\
\text { initiatives (propositions } 26 \\
\text { and 39), California, } 2000\end{array}$ & Share $>65$ & Opposition & Individualistic & Status quo & \\
\hline 60 & 23 & 2010 & $\begin{array}{c}\text { Hårsman \& } \\
\text { Quigley }\end{array}$ & Transportation & $\begin{array}{l}\text { Road toll to relieve conges- } \\
\text { tion, Stockholm, } 2006\end{array}$ & $\begin{array}{l}\text { Working-age popu- } \\
\text { lation as percentage } \\
\text { of total population }\end{array}$ & Opposition & Individualistic & Status quo & $\begin{array}{l}\text { The results imply that the el- } \\
\text { derly oppose the introduction } \\
\text { of a road toll, which was } \\
\text { proved to reduce congestion } \\
\text { during a trial period. }\end{array}$ \\
\hline 61 & 24 & 2011 & Wu \& Cutter & Transportation & $\begin{array}{c}\text { Passenger Rail and Clean Air } \\
\text { Bond Act (Proposition 156), } \\
\text { California, } 1992 \\
\text { Passenger Rail and Clean Air }\end{array}$ & Share $>65$ & Support & Collectivistic & Change & \\
\hline 62 & 24 & 2011 & Wu \& Cutter & Transportation & $\begin{array}{l}\text { Bond Act (Proposition 181), } \\
\text { California, } 1994\end{array}$ & Share $>65$ & Opposition & Individualistic & Status quo & \\
\hline 63 & 24 & 2011 & Wu \& Cutter & Transportation & $\begin{array}{l}\text { Imposed tax on retail sales of } \\
\text { gasoline to fund investments } \\
\text { in transportation infrastruc- } \\
\text { ture (Proposition 185), Cali- } \\
\text { fornia, } 1994\end{array}$ & Share $>65$ & Opposition & Individualistic & Status quo & \\
\hline 64 & 24 & 2010 & Wu \& Cutter & Environment & $\begin{array}{l}\text { Bonds for water projects } \\
\text { (clean polluted water) (Prop- } \\
\text { osition 204), California, } 1996\end{array}$ & Share $>65$ & $\begin{array}{c}\text { Not } \\
\text { significant }\end{array}$ & Neutral & Neutral & $\begin{array}{c}\text { Block level SAR results are in- } \\
\text { terpreted (preferred by the au- } \\
\text { thors). }\end{array}$ \\
\hline 65 & 24 & 2010 & Wu \& Cutter & Environment & $\begin{array}{l}\text { Prohibition on trapping fur- } \\
\text { bearing mammals (Proposi- } \\
\text { tion 4), California } 1998\end{array}$ & Share $>65$ & Opposition & Individualistic & Status quo & \\
\hline 66 & 24 & 2010 & Wu \& Cutter & Energy & $\begin{array}{l}\text { Tax credits for emission re- } \\
\text { ductions (Proposition 7), Cali- } \\
\text { fornia, } 1998\end{array}$ & Share $>65$ & Opposition & Individualistic & Status quo & \\
\hline 67 & 24 & 2010 & Wu \& Cutter & Environment & $\begin{array}{c}\text { Bonds for water, forests, and } \\
\text { open space (Proposition 12), } \\
\text { California, } 2000\end{array}$ & Share $>65$ & Opposition & Individualistic & Status quo & \\
\hline
\end{tabular}




\begin{tabular}{|c|c|c|c|c|c|c|c|c|c|c|}
\hline$\#$ & ID & Year & Author & Category & Referendum & Age variable ${ }^{a}$ & & Attitude $^{b}$ & & Note \\
\hline 68 & 24 & 2010 & Wu \& Cutter & Infrastructure & $\begin{array}{c}\text { Bonds for Water Infrastruc- } \\
\text { ture (Proposition 13), Califor- } \\
\text { nia, } 2000\end{array}$ & Share $>65$ & Opposition & Individualistic & Status quo & \\
\hline 69 & 24 & 2010 & Wu \& Cutter & Infrastructure & $\begin{array}{l}\text { Bonds for county jails (Propo- } \\
\text { sition 205), California, } 1996\end{array}$ & Share $>65$ & Support & Collectivistic & Change & \\
\hline 70 & 24 & 2010 & Wu \& Cutter & $\begin{array}{c}\text { School } \\
\text { spending }\end{array}$ & $\begin{array}{l}\text { Bonds for education (Proposi- } \\
\text { tion 1A), California, } 1998\end{array}$ & Share $>65$ & Opposition & Individualistic & Status quo & \\
\hline 71 & 25 & 2011 & Ahlfeldt & $\begin{array}{c}\text { Urban } \\
\text { development }\end{array}$ & $\begin{array}{l}\text { Urban development project } \\
\text { "Mediaspree," Berlin, } 2008\end{array}$ & Share 18-45 & Support & Collectivistic & Change & $\begin{array}{l}\text { 18-45-years-olds opposed the } \\
\text { project (yes vote), implying } \\
\text { support by the elderly. }\end{array}$ \\
\hline 72 & 26 & 2011 & $\begin{array}{l}\text { Ahlfeldt \& } \\
\text { Maennig }\end{array}$ & Sports facility & $\begin{array}{l}\text { Allianz-Arena (soccer) and } \\
\text { subsidized infrastructure, Mu- } \\
\text { nich, } 2001\end{array}$ & Share $>60$ & Support & Collectivistic & Change & $\begin{array}{l}\text { OLS result interpreted (pre- } \\
\text { ferred by the authors). The SAR } \\
\text { result is insignificant. }\end{array}$ \\
\hline 73 & 27 & 2012 & $\begin{array}{l}\text { Heintzelman } \\
\text { et al. }\end{array}$ & $\begin{array}{c}\text { Urban } \\
\text { development }\end{array}$ & $\begin{array}{c}\text { Introduction of urban growth } \\
\text { boundaries (Green Acres Pro- } \\
\text { gram), New Jersey, 1989- } \\
2009\end{array}$ & Share $>65$ & Support & Individualistic & Status quo & \\
\hline 74 & 28 & 2013 & Wagschal & Transportation & $\begin{array}{l}\text { State financing for Stuttgart } \\
21 \text { railway project }\end{array}$ & Average age & $\begin{array}{c}\text { Not } \\
\text { significant }\end{array}$ & Neutral & Neutral & $\begin{array}{c}\text { Analyzes the Stuttgart } 21 \text { refer- } \\
\text { endum at the level of } 44 \text { coun- } \\
\text { ties. }\end{array}$ \\
\hline 75 & 29 & 2014 & $\begin{array}{l}\text { Hersch \& } \\
\text { Pelkowski }\end{array}$ & $\begin{array}{l}\text { Health } \\
\text { services }\end{array}$ & $\begin{array}{c}\text { Fluoridation of public water, } \\
\text { Wichita, } 1978\end{array}$ & Share $>65$ & Opposition & Individualistic & Status quo & $\begin{array}{l}\text { Fluoridation is argued to have } \\
\text { positive effects for the dental }\end{array}$ \\
\hline 76 & 29 & 2014 & $\begin{array}{l}\text { Hersch \& } \\
\text { Pelkowski }\end{array}$ & $\begin{array}{l}\text { Health } \\
\text { services }\end{array}$ & $\begin{array}{l}\text { Fluoridation of public water, } \\
\text { Wichita, } 2012\end{array}$ & Share $>65$ & Opposition & Individualistic & Status quo & $\begin{array}{l}\text { health of children, but the el- } \\
\text { derly may regard themselves as }\end{array}$ \\
\hline 77 & 29 & 2014 & $\begin{array}{l}\text { Hersch \& } \\
\text { Pelkowski }\end{array}$ & $\begin{array}{l}\text { Health } \\
\text { services }\end{array}$ & $\begin{array}{l}\text { Fluoridation of public water, } \\
\text { Portland, } 2013\end{array}$ & Share $>65$ & $\begin{array}{c}\text { Not } \\
\text { significant }\end{array}$ & Neutral & Neutral & $\begin{array}{l}\text { more prone to alleged adverse } \\
\text { effects, such as kidney disease. }\end{array}$ \\
\hline 78 & 30 & 2015 & $\begin{array}{l}\text { Ahlfeldt \& } \\
\text { Maennig }\end{array}$ & Transportation & $\begin{array}{l}\text { New aviation concept, Berlin, } \\
2008\end{array}$ & Share $>55$ & Support & Collectivistic & Change & $\begin{array}{c}\text { The referendum challenged the } \\
\text { status quo (new aviation con- } \\
\text { cept). }\end{array}$ \\
\hline 79 & 31 & 2015 & $\begin{array}{l}\text { Coates \& } \\
\text { Wicker }\end{array}$ & Sports facility & $\begin{array}{l}\text { Winter Olympics 2022, Mu- } \\
\text { nich, } 2013\end{array}$ & Share 18-64 & $\begin{array}{c}\text { Not } \\
\text { significant }\end{array}$ & Neutral & Neutral & \\
\hline
\end{tabular}




\begin{tabular}{|c|c|c|c|c|c|c|c|c|c|c|}
\hline$\#$ & ID & Year & Author & Category & Referendum & Age variable ${ }^{a}$ & & Attitude $^{b}$ & & Note \\
\hline 80 & 32 & 2015 & Horn et al. & Sports facility & $\begin{array}{l}\text { Seahawk Stadium (subsi- } \\
\text { dized), Washington } 1997\end{array}$ & Share $>65$ & Support & Collectivistic & Change & \\
\hline 81 & 32 & 2015 & Horn et al. & $\begin{array}{l}\text { School } \\
\text { spending }\end{array}$ & $\begin{array}{l}\text { Extended period of voter-ap- } \\
\text { proved school district levies } \\
\text { (Resolution 4208), Washing- } \\
\text { ton, } 1997\end{array}$ & Share $>65$ & Opposition & Individualistic & Status quo & \\
\hline 82 & 32 & 2015 & Horn et al. & Infrastructure & $\begin{array}{l}\text { Government loans for the } \\
\text { conservation of more effi- } \\
\text { cient use of storm water and } \\
\text { sewer services (Resolution } \\
\text { 4209), Washington, } 1997\end{array}$ & Share $>65$ & Opposition & Individualistic & Status quo & \\
\hline 83 & 33 & 2015 & $\begin{array}{c}\text { Funk \& } \\
\text { Gathmann }\end{array}$ & Integration & $\begin{array}{c}\text { Pro joining international or- } \\
\text { ganizations, pooled EEA 1992, } \\
\text { EU } 2000 \& 2001, \text { UN 1986, } \\
2002\end{array}$ & Age & Opposition & Individualistic & Status quo & \\
\hline 84 & 33 & 2015 & $\begin{array}{l}\text { Funk \& } \\
\text { Gathmann }\end{array}$ & Integration & $\begin{array}{l}\text { Restricting foreign immigra- } \\
\text { tion, pooled } 1988,2000 \& \\
2002\end{array}$ & Age & Support & Individualistic & Change & $\begin{array}{l}\text { Interpretation analogous to } \\
\text { vote on integration }\end{array}$ \\
\hline 85 & 33 & 2015 & $\begin{array}{c}\text { Funk \& } \\
\text { Gathmann }\end{array}$ & Integration & $\begin{array}{l}\text { For easier Naturalization of } \\
\text { foreigners, } 1994\end{array}$ & Age & Opposition & Individualistic & Status quo & $\begin{array}{c}\text { Interpretation analogous to } \\
\text { vote on integration }\end{array}$ \\
\hline 86 & 33 & 2015 & $\begin{array}{l}\text { Funk \& } \\
\text { Gathmann }\end{array}$ & $\begin{array}{l}\text { Law enforce- } \\
\text { ment \& de- } \\
\quad \text { fense }\end{array}$ & $\begin{array}{l}\text { Pro less military (expendi- } \\
\text { tures), pooled 1989, 1992, } \\
\text { 2000, 2001, } 2003\end{array}$ & Age & Opposition & Individualistic & Status quo & \\
\hline 87 & 33 & 2015 & $\begin{array}{l}\text { Funk \& } \\
\text { Gathmann }\end{array}$ & Environment & $\begin{array}{l}\text { Pro protection of the environ- } \\
\text { ment, pooled 1987, } 1992(2 x) \text {, } \\
1994,2000(3 x), 2001,2003\end{array}$ & Age & Opposition & Individualistic & Status quo & \\
\hline 88 & 33 & 2015 & $\begin{array}{c}\text { Funk \& } \\
\text { Gathmann }\end{array}$ & Energy & $\begin{array}{l}\text { Against nuclear energy, } \\
\text { pooled 1984, } 1990(2 x), 2003 \\
(2 x)\end{array}$ & Age & Opposition & Individualistic & Status quo & \\
\hline 89 & 33 & 2015 & $\begin{array}{l}\text { Funk \& } \\
\text { Gathmann }\end{array}$ & Transport & $\begin{array}{l}\text { Against further road con- } \\
\text { struction, pooled } 1990(4 x)\end{array}$ & Age & Opposition & Collectivistic & Change & \\
\hline
\end{tabular}




\begin{tabular}{|c|c|c|c|c|c|c|c|c|c|c|}
\hline$\#$ & ID & Year & Author & Category & Referendum & Age variable ${ }^{a}$ & & Attitude $^{b}$ & & Note \\
\hline 90 & 33 & 2015 & $\begin{array}{l}\text { Funk \& } \\
\text { Gathmann }\end{array}$ & Transport & $\begin{array}{l}\text { Pro lower speed limit (30 } \\
\text { km/h), } 2001\end{array}$ & Age & $\begin{array}{c}\text { Not } \\
\text { significant }\end{array}$ & Neutral & Neutral & \\
\hline 91 & 33 & 2015 & $\begin{array}{l}\text { Funk \& } \\
\text { Gathmann }\end{array}$ & Transport & $\begin{array}{l}\text { Pro higher speed limit } \\
(130 / 100 \mathrm{~km} / \mathrm{h}), 1989\end{array}$ & Age & $\begin{array}{c}\text { Not } \\
\text { significant }\end{array}$ & Neutral & Neutral & \\
\hline 92 & 33 & 2015 & $\begin{array}{l}\text { Funk \& } \\
\text { Gathmann }\end{array}$ & Transport & $\begin{array}{l}\text { Against federal subsidies for } \\
\text { parking spaces, } 1996\end{array}$ & Age & $\begin{array}{c}\text { Not } \\
\text { significant }\end{array}$ & Neutral & Neutral & \\
\hline 93 & 33 & 2015 & $\begin{array}{l}\text { Funk \& } \\
\text { Gathmann }\end{array}$ & Transport & $\begin{array}{c}\text { Pro public transit, pooled } \\
1991,1992,1998\end{array}$ & Age & $\begin{array}{c}\text { Not } \\
\text { significant }\end{array}$ & Neutral & Neutral & \\
\hline 94 & 33 & 2015 & $\begin{array}{l}\text { Funk \& } \\
\text { Gathmann }\end{array}$ & Agriculture & $\begin{array}{l}\text { Pro abolishing subsidies for } \\
\text { agriculture, pooled 1985, } \\
1994\end{array}$ & Age & $\begin{array}{l}\text { Not } \\
\text { significant }\end{array}$ & Neutral & Neutral & \\
\hline 95 & 33 & 2015 & $\begin{array}{l}\text { Funk \& } \\
\text { Gathmann }\end{array}$ & Agriculture & $\begin{array}{l}\text { Pro liberalizing agriculture, } \\
\text { pooled } 1995(3 x), 1998\end{array}$ & Age & Opposition & Individualistic & Status quo & \\
\hline 96 & 33 & 2015 & $\begin{array}{l}\text { Funk \& } \\
\text { Gathmann }\end{array}$ & Moralities & $\begin{array}{l}\text { Pro equal rights for women, } \\
\text { pooled } 1981,1985,2000\end{array}$ & Age & $\begin{array}{c}\text { Not } \\
\text { significant }\end{array}$ & Neutral & Neutral & \\
\hline 67 & 33 & 2015 & $\begin{array}{l}\text { Funk \& } \\
\text { Gathmann }\end{array}$ & $\begin{array}{l}\text { Direct democ- } \\
\text { racy }\end{array}$ & $\begin{array}{l}\text { Pro more direct democracy, } \\
\text { pooled 191, } 2000(2 x), 2003\end{array}$ & Age & Opposition & Individualistic & Status quo & $\begin{array}{l}\text { Elderly assumed to (still) per- } \\
\text { ceive themselves as a minority } \\
\text { with limited impact in polls }\end{array}$ \\
\hline 68 & 33 & 2015 & $\begin{array}{l}\text { Funk \& } \\
\text { Gathmann }\end{array}$ & Health & $\begin{array}{l}\text { Pro subsidized health insur- } \\
\text { ance, pooled 1992, } 1994\end{array}$ & Age & $\begin{array}{c}\text { Not } \\
\text { significant }\end{array}$ & Neutral & Neutral & \\
\hline 99 & 33 & 2015 & $\begin{array}{l}\text { Funk \& } \\
\text { Gathmann }\end{array}$ & $\begin{array}{l}\text { Law enf. \& de- } \\
\quad \text { fense }\end{array}$ & $\begin{array}{l}\text { Pro liberalizing drug policy, } \\
\text { pooled } 1998,1999\end{array}$ & Age & Opposition & Individualistic & Status quo & $\begin{array}{l}\text { Vote against liberal drug policy } \\
\text { interpreted as vote for safety }\end{array}$ \\
\hline 100 & 33 & 2015 & $\begin{array}{l}\text { Funk \& } \\
\text { Gathmann }\end{array}$ & Health & $\begin{array}{l}\text { Pro tobacco and alcohol re- } \\
\text { strictions, pooled } 1993(2 x)\end{array}$ & Age & Support & Individualistic & Change & \\
\hline 101 & 33 & 2015 & $\begin{array}{l}\text { Funk \& } \\
\text { Gathmann }\end{array}$ & Moralities & $\begin{array}{l}\text { Pro gene-tec and animal ex- } \\
\text { periment restrictions, pooled } \\
1985,1992,1993,1998\end{array}$ & Age & $\begin{array}{l}\text { Not } \\
\text { significant }\end{array}$ & Neutral & Neutral & \\
\hline 102 & 33 & 2015 & $\begin{array}{l}\text { Funk \& } \\
\text { Gathmann }\end{array}$ & Moralities & Pro legalized abortion, 2002 & Age & $\begin{array}{c}\text { Not } \\
\text { significant }\end{array}$ & Neutral & Neutral & \\
\hline 103 & 33 & 2015 & $\begin{array}{l}\text { Funk \& } \\
\text { Gathmann }\end{array}$ & Health & $\begin{array}{l}\text { Pro subsidies for health sec- } \\
\text { tor (hospitals and pharma), } \\
2000\end{array}$ & Age & $\begin{array}{l}\text { Not } \\
\text { significant }\end{array}$ & Neutral & Neutral & \\
\hline
\end{tabular}




\begin{tabular}{|c|c|c|c|c|c|c|c|c|c|c|}
\hline \# & ID & Year & Author & Category & Referendum & Age variable $^{a}$ & & Attitude $^{b}$ & & Note \\
\hline 104 & 33 & 2015 & $\begin{array}{c}\text { Funk \& } \\
\text { Gathmann }\end{array}$ & $\begin{array}{l}\text { School spend- } \\
\text { ing }\end{array}$ & $\begin{array}{l}\text { Pro secured free education, } \\
1986\end{array}$ & Age & $\begin{array}{c}\text { Not } \\
\text { significant }\end{array}$ & Neutral & Neutral & \\
\hline 105 & 33 & 2015 & $\begin{array}{c}\text { Funk \& } \\
\text { Gathmann }\end{array}$ & Welfare & $\begin{array}{l}\text { Pro reductions in unemploy- } \\
\text { ment benefits }\end{array}$ & Age & Support & Individualistic & Change & \\
\hline 106 & 33 & 2015 & $\begin{array}{c}\text { Funk \& } \\
\text { Gathmann }\end{array}$ & Welfare & $\begin{array}{l}\text { Against increase in retirement } \\
\text { age, pooled } 1995,1998,2000 \\
(2 x)\end{array}$ & Age & Opposition & Individualistic & Change & $\begin{array}{c}\text { Older people are more likely to } \\
\text { be retired and therefore less } \\
\text { likely affected by the policy }\end{array}$ \\
\hline 107 & 33 & 2015 & $\begin{array}{c}\text { Funk \& } \\
\text { Gathmann }\end{array}$ & Welfare & $\begin{array}{c}\text { Pro increase in retirement } \\
\text { age, } 1995\end{array}$ & Age & $\begin{array}{c}\text { Not } \\
\text { significant }\end{array}$ & Neutral & Neutral & \\
\hline 108 & 33 & 2015 & $\begin{array}{c}\text { Funk \& } \\
\text { Gathmann }\end{array}$ & Moralities & $\begin{array}{l}\text { Pro equal rights for disabled, } \\
\qquad 2003\end{array}$ & Age & $\begin{array}{l}\text { Not } \\
\text { significant }\end{array}$ & Neutral & Neutral & \\
\hline 109 & 33 & 2015 & $\begin{array}{c}\text { Funk \& } \\
\text { Gathmann }\end{array}$ & Welfare & $\begin{array}{l}\text { Pro longer maternaty leave, } \\
\text { pooled } 1984(2 x), 1999\end{array}$ & Age & Opposition & Individualistic & Status quo & \\
\hline 110 & 33 & 2015 & $\begin{array}{c}\text { Funk \& } \\
\text { Gathmann }\end{array}$ & Culture & $\begin{array}{l}\text { Pro promotion of culture, } \\
\text { pooled } 1984,1986\end{array}$ & Age & Opposition & Individualistic & Status quo & \\
\hline 111 & 33 & 2015 & $\begin{array}{c}\text { Funk \& } \\
\text { Gathmann }\end{array}$ & Welfare & $\begin{array}{l}\text { Pro reduction of working } \\
\text { hours, pooled 1985, 1985, } \\
1993,2002\end{array}$ & Age & Opposition & Individualistic & Status quo & $\begin{array}{l}\text { Reduction of working hours } \\
\text { benefits the workforce / young }\end{array}$ \\
\hline 112 & 33 & 2015 & $\begin{array}{c}\text { Funk \& } \\
\text { Gathmann }\end{array}$ & $\begin{array}{l}\text { Urban devel- } \\
\text { opment }\end{array}$ & Pro rent control, 2003 & Age & $\begin{array}{c}\text { Not } \\
\text { significant }\end{array}$ & Neutral & Neutral & \\
\hline
\end{tabular}

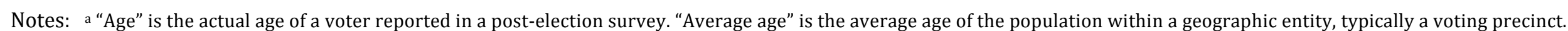

"Share $\lessgtr X "$ is the share of residents above or below a certain age within a geographic entity, typically a voting precinct. b Support/Not significant/Opposition indicate that the age effect on support in the referendum was significantly positive/not significant/significantly negative. Attitude is interpreted as individualistic if the age effect on support is significant and in line with the definitions in Table 6 in the main paper (unless otherwise indicated in the note), collectivistic if significant and pointing in the opposite direction, and neutral otherwise (insignificant effect on support). Attitude is status quo/neutral/change if the effect on support is significant and the direction implies that the status quo would be maintained/the effect on support is insignificant/the effect on support is significant and in a direction that implies a change of the status quo. 


\section{Approximation of turnout covered in the review}

To approximate the total number of voters who participated in the referendums that we consider in our quantitative literature review we proceed as follows. For 10 out of the 112 referendum analyses considered the number of voters who turned out at the ballots was reported by the authors. For 28 of the remaining referendum analyses we were able to locate the actual numbers from official sources such as websites of country, state or county statistical offices.

For 40 additional referendum analyses we approximate the number of voters by multiplying the population residing within the respective locality by the percentage turnout and an approximation of the share of the adult population, which we set to $80 \%$. For 65 referendum analyses we were able to locate the actual percentage turnout or the turnout in a referendum on a similar topic in a near locality in a near year. For some remaining 16 US referendum analyses (in 7 studies) we use the "average voter turnout for local measures in California, 2015 " (35,46\%) as an approximation. While each referendum analysis normally focuses on one referendum, there is a limited number of referendum analyses that use pooled samples of various referendums. Banzhaf et al. (2010) provide a pooled analysis of 1,550 US open space referendums. We approximate the total turnout in these referendums based on the turnout in a random sample of 45 referendums (five from each year). Similarly, we approximate the turnout in the 84 referendums analyzed by Funk \& Gathmann (2015) in 30 referendum analyses by multiplying the number of referendums (84) by the average turnout in Swiss referendums in our data (approximately two million).

We note that Thalmann (2004) and Bornstein \& Lanz (2008) analyze the same referendums. While we consider the estimates from both studies in the quantitative literature review, the voters participating in these referendums are counted just once. Because of overlap with Banzhaf et al. (2010) we do not count the referendums analyzed (in another pooled analysis) by Kotchen \& Powers (2006). Similarly, the 2000 EMU referendum in Denmark, which is analyzed by Ahlfeldt et al. (2009) and Hobolt (2005) is counted just once.

Because it is possible that some of the referendums analyzed by Kotchen \& Powers (2006) are not covered by Banzhaf et al. (2010) our approximation of 400 million voters covered in the quantitative literature review can be considered a lower-bound estimate. 


\section{Definition of unambiguous sample}

The rules summarized in Table 6 in the main paper, in general, provide a guideline to the consistent classification of individualistic (or collectivistic) lifecycle attitudes. However, intergenerational differences in net benefits are more obvious for some categories (e.g. school spending) than others (e.g. sports and culture). Moreover, there are referendum-specific particularities that make certain cases fit less precisely with the general rules. These issues are likely to create measurement errors, which may bias the conditional category means and increase standard errors in the baseline model in Table 7 (Column 1). To address this concern, we restrict the sample to a set of referendums where we view the definition of individualistic lifecycle attitudes as largely uncontroversial.

We exclude referendums that fall into categories for which the economic argument as to whether or not a certain generation would be privileged is not entirely straightforward. These include referendums on moral questions such as on abortion policies, animal testing, and equal rights policies (the age effect was insignificant in all cases), law enforcement and defence, direct democracy, and liberalization of agriculture. We also exclude referendums on sports and culture because investments materialize relatively quickly and the relative benefits are determined by relative preferences of different age groups, which can vary across institutional contexts.

Following a similar logic, we exclude transport referendums if they are concerned with projects that can be implemented in the short-run, e.g. investments into bus services. In contrast, we keep referendums on projects involving major investments into durable capital (e.g. railway infrastructure or road construction). Moreover, we exclude one referendum held in Stockholm on congestion charging because costs and benefits are presumably distributed similarly across age cohorts (mainly incurred by the working commuters). Applying the same rationale, we also exclude a number of referendums on environmental protection. If the benefits materialize in the short-run, e.g. if natural habitats such as water spacer or forests are protected, we exclude the referendums. If the projects have a longer time-horizon, e.g. improvement of polluted waters, we keep the referendums.

We also exclude a small number of referendums because local particularities complicate the application of the general classification scheme. As an example, in the airport referendum in Berlin (Ahlfeldt and Maennig, 2015), noise - to which older people may likely be more sensitive - was a major concern among voters, possibly confounding the results. Another example is Massachusetts' Proposition $21 / 2$ to restrict property tax, which is reported to have implications for school spending, but not exclusively (Ladd and Wilson, 1983). 


\section{Complementary estimates}

In the Table 7 in the main paper we already present a number of alterations of our baseline model estimating conditional means of lifecycle attitudes by referendum category. In Table A2 below we present a further series of complementary model estimates.

We begin by separately estimating the baseline model for referendums in the US (1) and in Europe (2). The estimates are largely qualitatively consistent with the baseline model. The most notable exception is the school spending effect, which is not only insignificant, but also close to zero for European referendums. We note, however, that just two out of 16 referendums in the school spending category were held in Europe.

Next, we use the unambiguous sample described in the previous section in a weighted (by the inverse of the number of referendums in a study) version and in a model where we add a control for a referendum location in the US. The results are very similar to the baseline model reported in Table 7 , Column (5) in the main paper.

The last three columns show variations of Column (7) in Table 7 in the main paper, which uses an index of reform orientation (pro status quo vs. pro change) as a dependent variable. We use the unambiguous sample (5), additionally weight observations (6) and add the US control (7). The main insight complementing the results reported in Table 7 in the main paper is that especially after controlling for a referendum location in the US there are fewer referendum categories with significant status quo orientation than significant individualistic preferences. This finding, once more, confirms that status quo orientation is not a sufficient explanation for the existence of individualistic attitudes. 
Tab A2. Elderly attitude: Alternative models

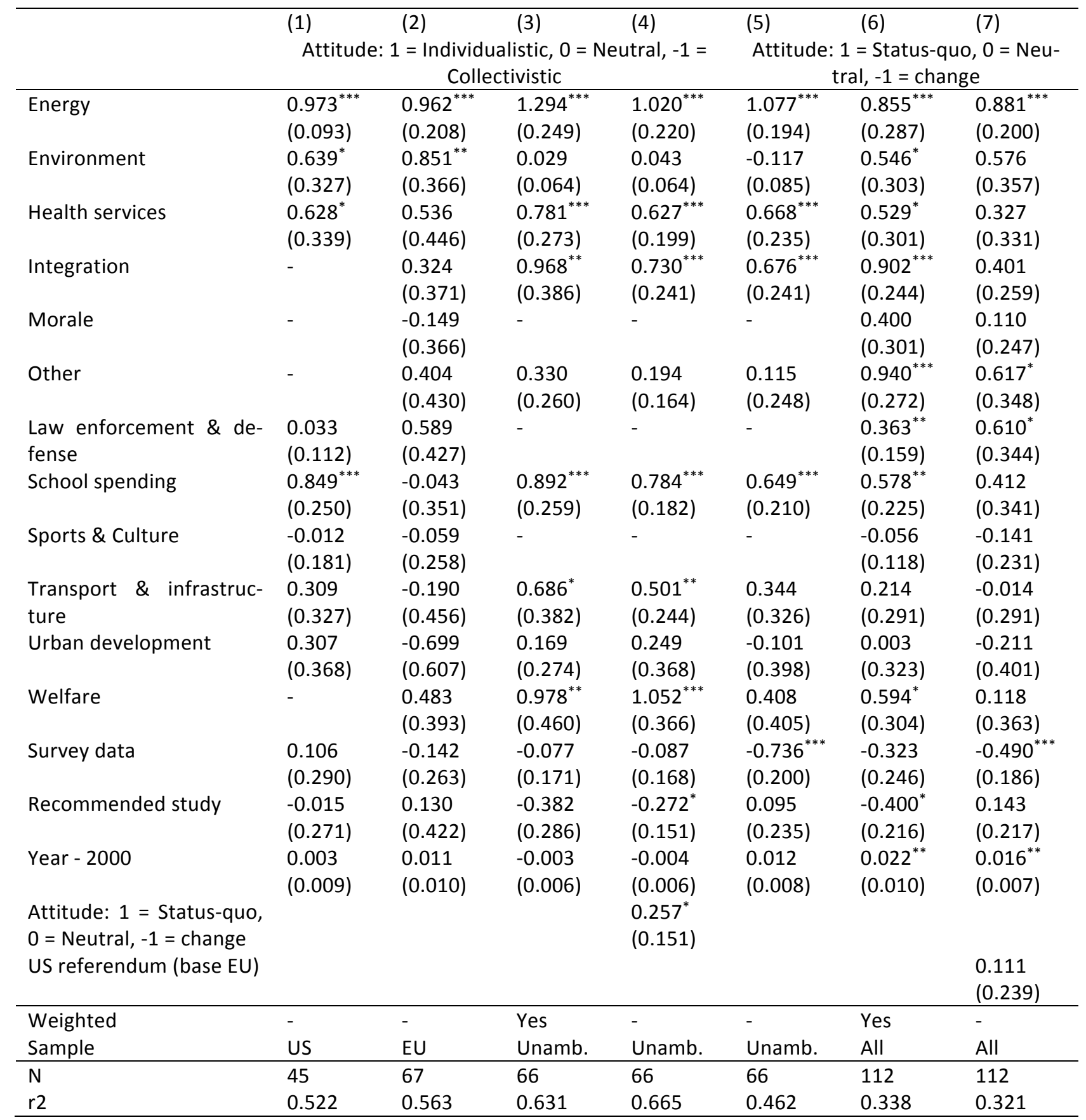

Notes: Regression excluding constant to allow for category specific intercepts. Category "other" includes agriculture $(2 x)$, direct democracy $(1 x)$, and foreign aid $(1 x)$. Weighted estimates are weighted by the inverse of the number of referendums in a study. Unambiguous is a sample that excludes referendums where the classification of elderly preferences was potentially controversial (a discussion is in Appendix II, Section 4) Standard errors (in parentheses). EU abbreviates Europe. ${ }^{*} p<0.1,{ }^{* *} p<0.05,{ }^{* * *} p<0.01$ 


\section{Literature}

Agostini, S. J., Quigley, J. M., \& Smolensky, E. (1997). Stickball in San Francisco. In R. G. Noll \& A. Zimbalist (Eds.), Sports, Jobs, and Taxes: The Economic Impact of Sports Teams and Stadiums (pp. 385-426). Washington, D.C.: Brookings Institution Press.

Ahlfeldt, G. M. (2011). Blessing or curse? Appreciation, amenities and resistance to urban renewal. Regional Science and Urban Economics, 41(1), 32-45.

Ahlfeldt, G. M., \& Maennig, W. (2011). Voting on a NIMBY facility: Proximity cost of an "iconic" stadium. Urban Affairs Review, 48(2), 205-237.

Ahlfeldt, G. M., \& Maennig, W. (2015). Homevoters vs. leasevoters: A spatial analysis of airport effects. Journal of Urban Economics, 87(0), 85-99.

Ahlfeldt, G. M., Maennig, W., \& Osterheider, T. (2009). Regional and Sectoral Effects of a Common Monetary Policy: Evidence from Euro Referenda in Denmark and Sweden Hamburg Contemporary Economic Discussions, 28.

Balsdon, E., Brunner, E. J., \& Rueben, K. (2003). Private demands for public capital: Evidence from school bond referenda. Journal of Urban Economics, 54(3), 610-638.

Banzhaf, H. S., Oates, W. E., \& Sanchirico, J. N. (2010). Success and design of local referenda for land conservation. Journal of Policy Analysis and Management, 29(4), 769-798.

Bornstein, N., \& Lanz, B. (2008). Voting on the environment: Price or ideology? Evidence from Swiss referendums. Ecological Economics, 67(3), 430-440.

Brunner, E., \& Balsdon, E. (2004). Intergenerational conflict and the political economy of school spending. Journal of Urban Economics, 56(2), 369-388.

Brunner, E. J., \& Ross, S. L. (2010). Is the median voter decisive? Evidence from referenda voting patterns. Journal of Public Economics, 94(11-12), 898-910.

Button, J. W. (1992). A sign of generational conflict: tThe impact of Florida's's aging voters on local school and tax referenda. Social Science Quarterly, 73(4), 786-797.

Coates, D., \& Humphreys, B. R. (2006). Proximity benefits and voting on stadium and arena subsidies. Journal of Urban Economics, 59(2), 285-299.

Coates, D., \& Wicker, P. (2015). Who voted against Munich's bid for the 2022 Winter Olympics? Working paper.

Dehring, C. A., Depken, C. A., \& Ward, M. R. (2007). A direct test of the homevoter hypothesis. AIES/IASE Working Paper, 07-19.

Dehring, C. A., Depken, C. A., \& Ward, M. R. (2008). A direct test of the homevoter hypothesis. Journal of Urban Economics, 64(1), 155-170.

Feigenbaum, S., Karoly, L., \& Levy, D. (1988). When votes are words not deeds: Some evidence from the Nuclear Freeze Referendum. Public Choice, 58(3), 201-216.

Fischel, W. A. (1979). Determinants of voting on environmental quality: A study of a New Hampshire pulp mill referendum. Journal of Environmental Economics and Management, 6(2), 107-118.

Funk, P., \& Gathmann, C. (2015). Gender gaps in policy making: evidence from direct democracy in Switzerland. Economic Policy, 30(81), 141-181.

Hårsman, B., \& Quigley, J. M. (2010). Political and public acceptability of congestion pricing: Ideology and self-interest. Journal of Policy Analysis and Management, 29(4), 854-874.

Heintzelman, M. D., Walsh, P. J., \& Grzeskowiak, D. J. (2012). A Multi-Method, Spatial Approach for Explaining the Appearance and Passage of Open Space Referenda. NCEE Working Paper, 1202.

Hersch, P. L., \& Pelkowski, J. E. (2014). Voter demand for fluoridated water: A tale of two c(av)ities. Applied Economics Letters, 21(1), 51-54.

Hobolt, S. B. (2005). When Europe matters: The impact of political information on voting behaviour in EU referendums. Journal of Elections, Public Opinion and Parties, 15(1), 85-109.

Horn, B. P., Cantor, M., \& Fort, R. (2015). Proximity and voting for professional sporting stadiums: the pattern of support for the Seahawk stadium referendum. Contemporary Economic Policy, in press.

Kotchen, M. J., \& Powers, S. M. (2006). Explaining the appearance and success of voter referenda for open-space conservation. Journal of Environmental Economics and Management, 52(1), 373390.

Ladd, H. F., \& Wilson, J. B. (1983). Who supports tax limitations: Evidence from Massachusetts' proposition 21/2. Journal of Policy Analysis and Management, 2(2), 256-279. 
Noam, E. (1982). Demand functions and the valuation of public goods. Public Choice, 38(3), 271280.

Pelinka, A. (1983). The nuclear power referendum in Austria. Electoral Studies, 2(3), 253-261.

Rubinfeld, D. L. (1977). Voting in a Local School Election: A Micro Analysis. The Review of Economics and Statistics, 59(1), 30-42.

Rushton, M. (2005). Support for earmarked public spending on culture: Evidence from a referendum in metropolitan Detroit. Public Budgeting \& Finance, 25(4), 72-85.

Schulze, G. G., \& Ursprung, H. W. (2000). La donna e mobile -- or is she? Voter preferences and public support for the performing arts. Public Choice, 102(1/2), 131-149.

Thalmann, P. (2004). The Public Acceptance of Green Taxes: 2 Million Voters Express Their Opinion. Public Choice, 119(1-2), 179-217.

Wagschal, U. (2013). Die Volksabstimmung zu Stuttgart 21 - ein direktdemokratisches Lehrstück? In U. Wagschal, U. Eith, \& M. Wehner (Eds.), Der historische Machtwechsel: Grün-rot in BadenWürtemberg (pp. 181-205). Berlin: Nomos.

Wu, X., \& Cutter, B. (2011). Who votes for public environmental goods in California?: Evidence from a spatial analysis of voting for environmental ballot measures. Ecological Economics, 70(3), 554-563. 